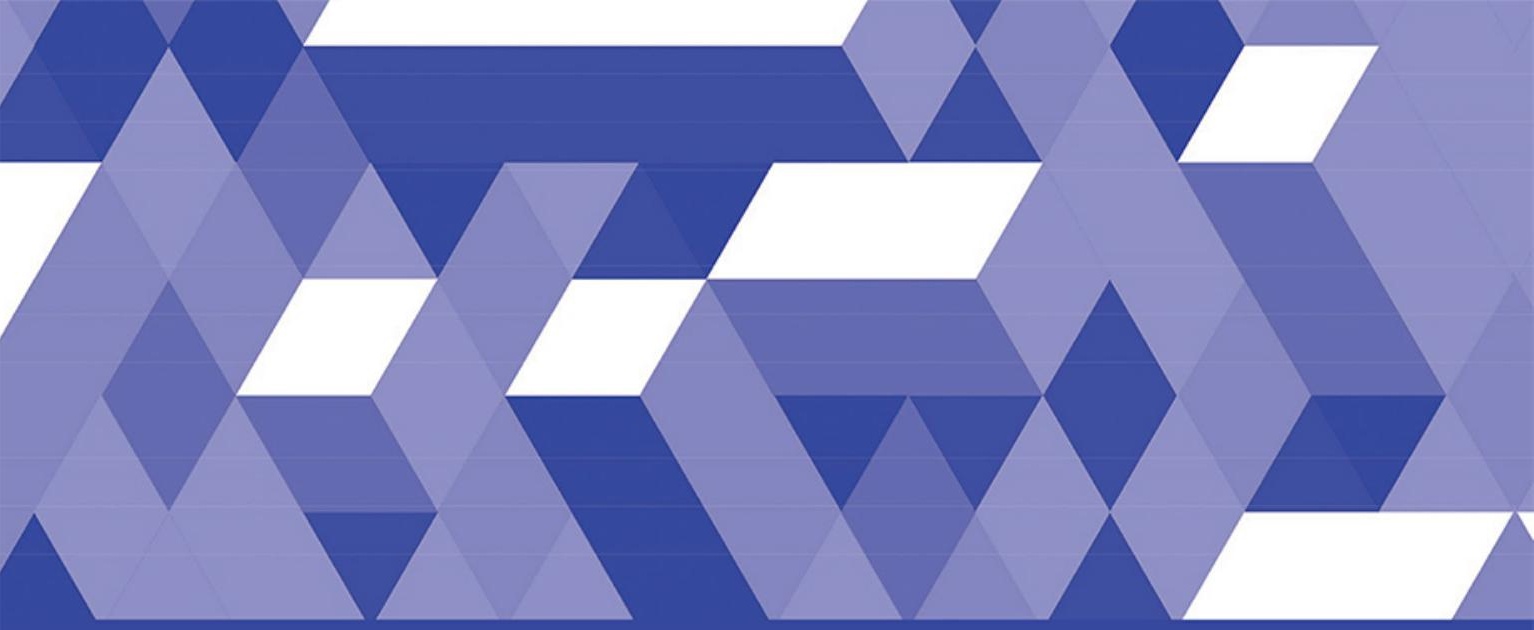

Theorizing Education Series

\title{
INDIRECT EDUCATION
}

EXPLORING INDIRECTNESS IN TEACHING AND RESEARCH

Herner Saeverot

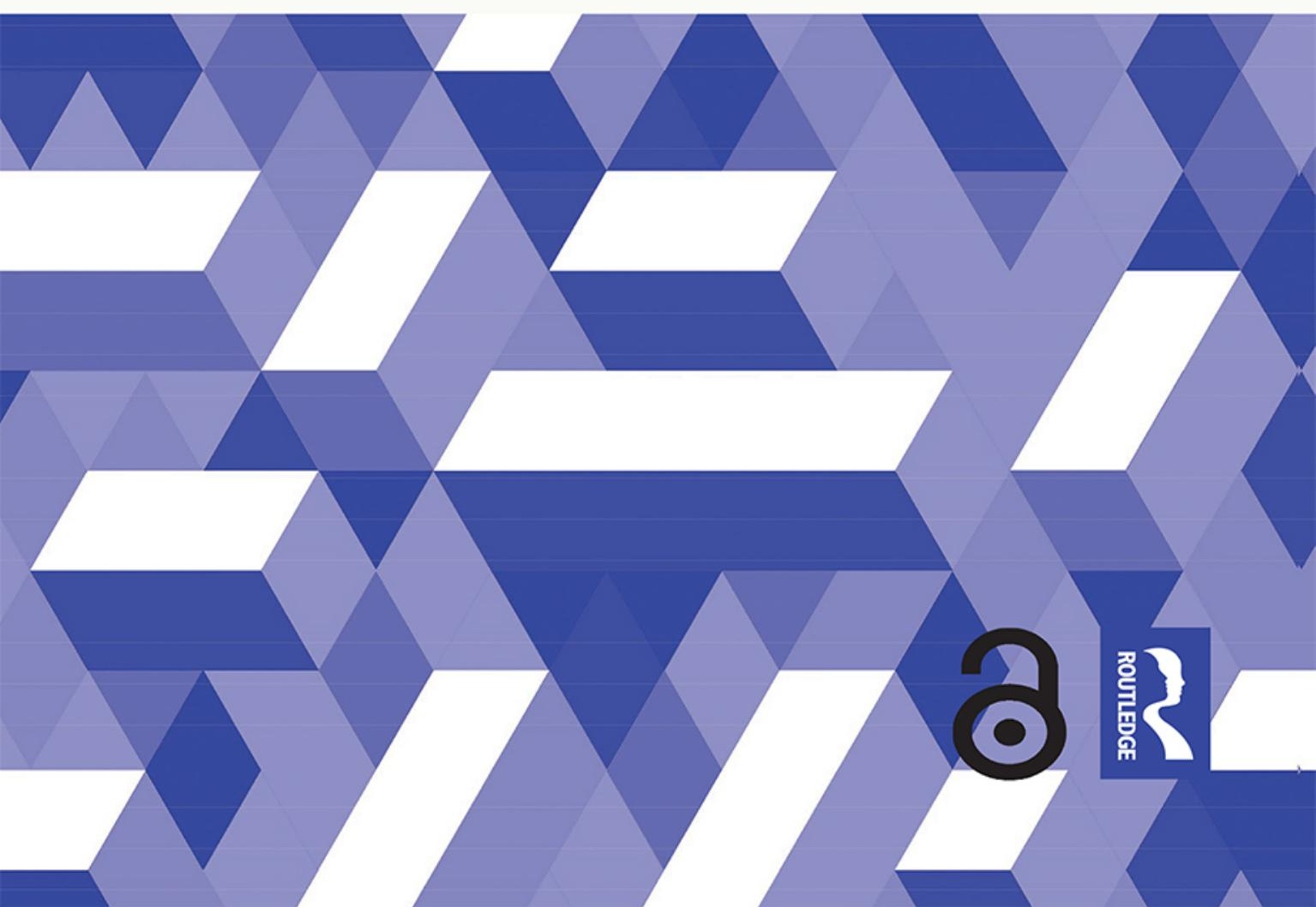




\section{Indirect Education}

Indirect Education discusses direct and indirect pedagogies and the complexities of these concepts within the field of education practice and research. It addresses the question of when it is most beneficial to be indirect with regard to teaching and educational research.

The book offers an original approach to education in how it reasserts our right to a sense of ownership and agency in educational explorations. It argues that there should be space for indirect ways of teaching and communication when matters without clear answers and objectives enter the educational sphere. Bringing together a mix of empirical studies presented with a degree of storytelling, the book explores the literature of educational theory to make a novel and relatable argument for making space for indirectness in learning contexts.

Putting forward a compelling case that is necessary for education in the difficult times that we are living in, the book will appeal to academics, researchers and students in the fields of educational theory, pedagogy, leadership studies and educational practice.

Herner Saeverot is Professor of Education at Western Norway University of Applied Sciences in Bergen and Professor II at NLA University College in Oslo, Norway. 


\section{Theorizing Education Series}

Theorizing Education brings together innovative work from a wide range of contexts and traditions which explicitly focuses on the roles of theory in educational research and educational practice. The series includes contextual and socio-historical analyses of existing traditions of theory and theorizing, exemplary use of theory, and empirical work where theory has been used in innovative ways. The distinctive focus for the series is the engagement with educational questions, articulating what explicitly educational function the work of particular forms of theorizing supports.

Series Editors

Gert Biesta, Maynooth University, Ireland and University of Edinburgh, UK

Stefano Oliverio, University of Naples “Federico II”, Italy

Phenomenology and Educational Theory in Conversation Back to Education Itself

Edited by Patrick Howard, Tone Saevi, Andrew Foran, and Gert Biesta

\section{A Pedagogy of Equality in a Time of Unrest}

Strategies for an Ambiguous Future

Carl Anders Safstrom

Moral Emotions and Human Interdependence in Character Education

Beyond the One-Dimensional Self

Agnieszka Bates

\section{Indirect Education}

Exploring Indirectness in Teaching and Research

Herner Saeverot

For more information about this series, please visit: www.routledge. com/Theorizing-Education/book-series/THEOED 


\section{Indirect Education}

Exploring Indirectness in Teaching and Research

Herner Saeverot 
First published 2022

by Routledge

2 Park Square, Milton Park, Abingdon, Oxon OXI4 4RN

and by Routledge

605 Third Avenue, New York, NY 10158

Routledge is an imprint of the Taylor \& Francis Group, an informa business

(C) 2022 Herner Saeverot

The right of Herner Saeverot to be identified as author of this work has been asserted in accordance with sections 77 and 78 of the Copyright, Designs and Patents Act 1988.

The Open Access version of this book, available at www.taylorfrancis.com, has been made available under a Creative Commons Attribution-Non Commercial-No Derivatives 4.0 license.

Trademark notice: Product or corporate names may be trademarks or registered trademarks, and are used only for identification and explanation without intent to infringe.

British Library Cataloguing-in-Publication Data

A catalogue record for this book is available from the British Library

Library of Congress Cataloging-in-Publication Data A catalog record has been requested for this book

ISBN: 978-I-032-06320-I (hbk)

ISBN: 978-I-032-06322-5 (pbk)

ISBN: 978-I-003-I9346-3 (ebk)

DOI: 10.4324/9781003193463

Typeset in Bembo

by SPi Technologies India Pvt Ltd (Straive) 


\section{Contents}

List of illustrations vii

About the author viii

Acknowledgements ix

Introduction: Expanding the forms of education 1

1 Justification: Education is indirect by nature-so what's the problem?

2 Teaching: Four forms of teaching. Excerpts from observations at a secondary school

3 Communication: Janus-faced forms of indirect communication. Teacher interview and thought experiments

4 Ethics: Where is the boundary between the ethical and the unethical regarding teachers' indirect actions? A case study

5 Time: How may 'genuine time' be an integral element in a student's existence? A case study

6 Education research:The direct and indirect paths of education research

7 The educational researcher: Ironic indirection and the ' $I$ ' in education research 
Afterword:The wisdom of teachers. A conversation with three teachers

Index 


\section{Illustrations}

\section{Figures}

2.1 Model for DI 21

2.2 Model for ISS 22

2.3 Model for ISU 24

2.4 Model for DIT 27

2.5 Model showing situations as to when DI, ISS and ISU/DIT were used during the observed teaching lessons and which fields and perspectives these forms of teaching are connected to 30

3.1 Education through the deceit 44

3.2 Teacher as intermediary between deceit and "truth" 45

6.1 The structure of SE 94

\section{Tables}

I.1 Overview of the concepts of direct and indirect 3

6.1 Overview of the different areas of education 91 


\section{About the author}

Herner Saeverot is Professor of Education at the Department of education, Western Norway University in Bergen, Norway. He is also Professor II at NLA University College in Oslo, Norway. His primary areas of scholarship are philosophy of education and history of educational theory and the academic discipline of educational science. His research interests include indirect pedagogy, existential education, unforeseeable education and literature and education. With Routledge, he has published Education and the Limits of Reason: Reading Dostoevsky, Tolstoy, and Nabokov (2018, in collaboration with Peter Roberts), and he is the editor of the volume Meeting the Challenges of Existential Threats through Educational Innovation: A Proposal for an Expanded Curriculum (2021). He is the founder and convenor of the Annual Bergen Educational Conversation (an international 'conversation' founded in 2009), and since 2015, he has been the editor-in-chief of the journal Nordic Studies in Education. In 2019, he was appointed member of the Royal Norwegian Society of Sciences and Letters. 


\section{Acknowledgements}

This book is a result of many years of teaching, researching and conversations that have taken place at different conferences, including the Annual Bergen Educational Conversation, all the way back to its foundation in 2009. A big thank you to all the research colleagues who have contributed to, and participated in, educational conversations in this forum. I am grateful to Prof. Dr. Glenn-Egil Torgersen, Prof. Dr. Gert Biesta, Prof. Dr. Carl Anders Säfström, Prof. Dr. Johannes Bellmann, Prof. Dr. John Baldacchino, Associate Professor Gerd Grimsaeth and Assistant Professor Christine Hope for many inspiring and thought-provoking conversations regarding questions of education and educational research. A special thank you to Prof. Dr. Tobias Christoph Werler for many constructive and critical comments on an earlier version of the book. I am also grateful to my institution for financing the Open Access book and to the teachers who have been willing to share their experiences and thoughts in this book. I am indebted to Emilie Coin at Routledge for her encouragement and commitment to the project, and the series editors of Theorizing Education, Gert Biesta and Stefano Oliverio, for being supportive from the very start. I would also like to thank the anonymous reviewers for helpful suggestions and advice, and the publisher for the copyedited text proof for the book.

Chapter 2 is based on Saeverot, H., Grimsaeth, G. and Hope, C. (2021). How Do Teachers Deal with Undemocratic Attitudes in Secondary School? "Evidence" from Norway. Policy Futures in Education, 0(0), 1-16. Chapter 5 is a considerably rewritten version of a paper published as Saeverot, H. and Torgersen, G.-E. (2020). Time, Individuality, and Interaction: A Case Study. In P. Howard, T. Saevi, A. Foran and G. Biesta (Eds.), Phenomenology and Educational Theory in Conversation. Back to Education Itself. New York and London: Routledge. 
$\Longrightarrow$ Taylor \& Francis

Taylor \& Francis Group

http://taylorandfrancis.com 


\section{Introduction}

\section{Expanding the forms of education}

\section{Education needs both directness and indirectness}

In 2013, my book Indirect Pedagogy. Some Lessons in Existential Education was published (Saeverot, 2013). The book intended to develop and increase knowledge on the concept of indirect pedagogy, where teachings are conducted indirectly. In many ways, Indirect Pedagogy was a response to a learning paradigm which has become widespread in Western education in recent years; for example, "the visible learning paradigm" (Nielsen \& Klitmøller, 2017). This particular paradigm or hegemony was developed by John Hattie, primarily in the book Visible Learning: $A$ Synthesis of over 800 Meta-analyses Relating to Achievement. In Visible Learning, published in 2009, Hattie highlights what he refers to as "direct instruction", meaning that teachers should point out directly, as explicitly and visibly as possible, what the students should do and how they should do it in a learning perspective (Hattie, 2009). According to Hattie (ibid.), direct instruction (or explicit instruction) is one of the most effective approaches to teaching and learning.

The purpose of this book is of course not to replace direct instruction with indirect pedagogy. There are several positive aspects of direct instruction being used in teaching situations. Not least, Hattie provides strong 'evidence' that direct instruction is quite effective when it comes to the learning of reading and other skills (Hattie \& Zierer, 2018). The point being in this book is rather that Hattie, by way of direct instruction, relates to a concept of learning which is very much about developing certain skills and acquiring knowledge in a somewhat narrow manner (McKnight \& Whitburn, 2018). However, this concept of learning is only a rather small part of education.

Broadly, education can be defined as having two main purposes. On the one hand, the purpose consists of a pedagogy for what is good for the individual, and on the other hand, it consists of a pedagogy for what is good for humankind (Kemmis, 2012; Kemmis \& Edwards-Groves, 2018). It is about living well in a world worth living in. This is the double purpose of education, which has an individual and a social perspective, where the goal is to educate individuals who feel obligated to act for the best of fellow human beings and society (Kemmis \& Edwards-Groves, 2018, p. 2). (In Chapter 6, I also define the concept of education research.) 
To teach from the principle of direct instruction only is therefore far from enough, as directness alone cannot reach such a broad and multifaceted purpose. Teaching, so I shall argue, also needs to be indirect, e.g. when it comes to existential issues, which is inherent in the double purpose of education. Existence is not an objective matter, where goals can be clarified in advance. On the contrary, existence is a subjective matter. Therefore, no one has the right to tell others how they should live their lives. Every human being should find out for themselves how they wish to exist and be in the world. Nevertheless, education may have a role in the students' existence and being in the world, but a prerequisite for doing so is to teach beyond the principle of direct instruction.

If education becomes unilaterally concerned with direct instruction, the educational language in the form of teaching can easily become overloaded with expectations that are too detailed and exact; however, such expectations find their limits in unforeseeable situations (Bollnow, 1956; Torgersen \& Saeverot, 2015). In cases that are unforeseeable, it is essential to make room for the language's richness of indirect words, expressions and phrases. That is the reason why this book argues that there should also be space for indirect ways of teaching. Not only that, but this book also argues that there should be space for indirectness in educational research. The reason being that there is a tendency to believe in reliable information, which can be extrapolated more or less directly to educational practice (see, e.g., Slavin, 2020; for a critical discussion see Biesta, 2008; Bridges, Smeyers, \& Smith, 2009; Maritzen, 2018).

Throughout the book, I will explore the wisdom of educationists (both teachers and educational researchers). To be wise as an educationist, so I argue, is to know when to be direct and indirect and also when to combine the two forms in relation to teaching and education research. Moreover, it is about knowing both the positive and educative effects, as well as the negative and detrimental effects of both directness and indirectness related to teaching and education research. I will offer several examples of this so that the book can provide increased awareness of direct and indirect approaches in both educational practice and educational research. Since the theme of indirectness in education is more or less unexplored, the book strongly encourages more research on this theme, both related to educational practice and educational research.

\section{The concepts of direct and indirect}

Before I go on to argue on these issues, we need to have an understanding of how the concepts of indirect and direct may be signified. As an attempt to clarify the two concepts, I have developed a table. The word explanations in Table I.1 have their origin in the Oxford Advanced Learner's Dictionary of English, while the examples to the right are created by me.

Direct can be thought of as a straightforward approach or as a straight line. For example, we choose the straightest and fastest way to the goal, or the teacher is showing and explaining to the students explicitly what to do and how to do it. Whereas direct can be thought of as a straight line, indirect can be thought of as a crooked road. For example, the student chose to take a detour to school, using side streets and 
Table I.I Overview of the concepts of direct and indirect

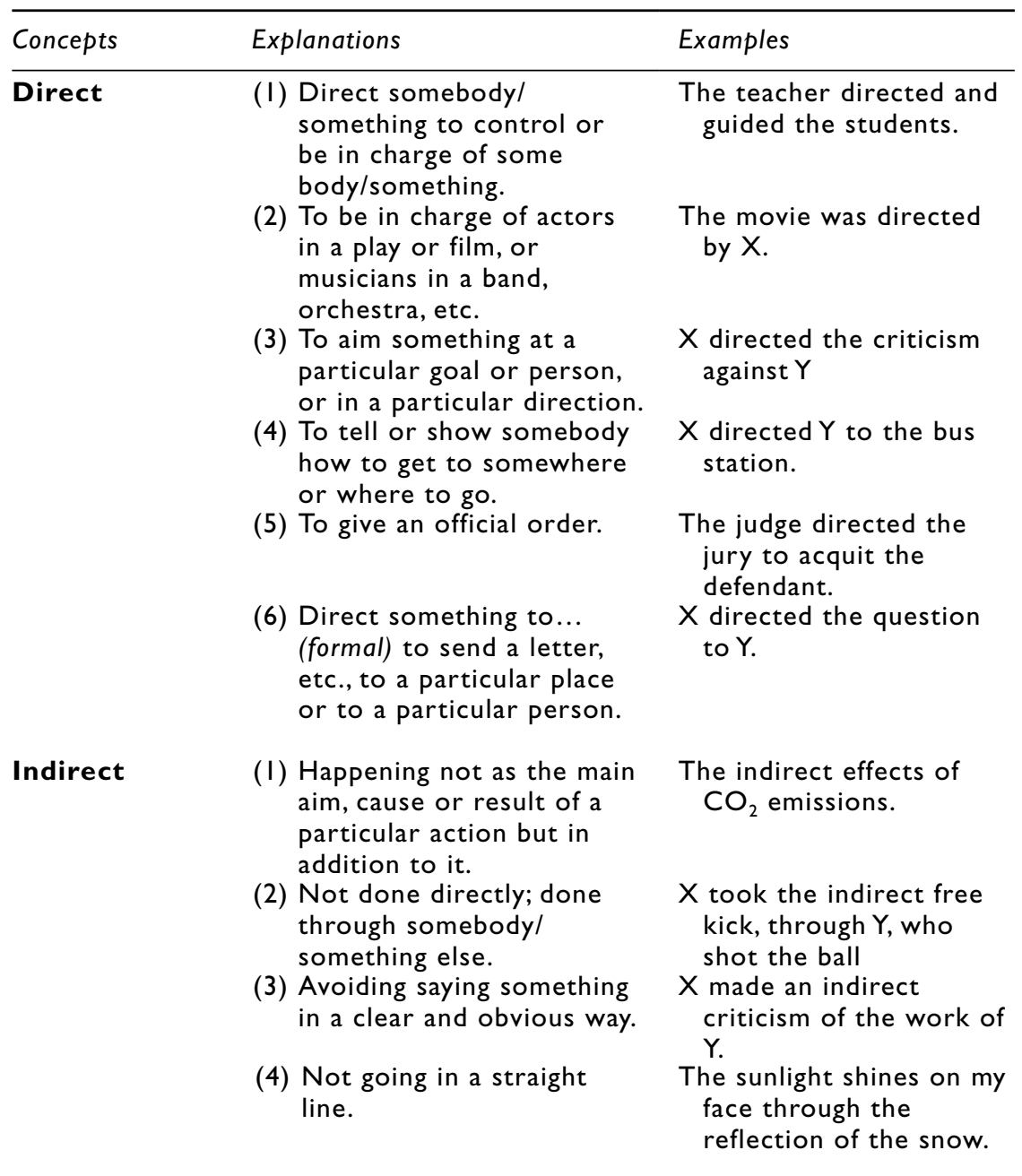

back roads. In football (US: soccer), to take another example, there are two kinds of free kick. First, there is the direct free kick in which the ball can be shot directly against the goal of the opposing side. Secondly, there is the indirect free kick, meaning that it is not allowed to shoot the ball in the goal on the first touch. When a player kicks the ball as the first person after the referee has blown the whistle, the same player cannot touch the ball until an opponent or co-player has touched the ball. This means that the ball must go through a co-player before it can be shot against the goal.

Similar thoughts can be found in educational situations. Consider the teaching of history for example. We cannot meet past historical events directly. Historical events belong to the past and can only be conveyed indirectly-for example, through a 
textbook. This is how the textbook appears as an intermediary or intercessor. What is an intermediary? An intermediary operates between teachers and students and prevents a direct or straightforward route. An intermediary is not necessarily an educational means but can be made into one by the teacher. As a teacher, different intermediaries can be exploited educationally by the fact that some intermediaries can have strong impacts on the students without the teacher being able to control this fully. For example, instead of or in addition to using textbooks, the teacher can make use of photographs or films based on the cruelties that happened in Auschwitz (in Polish: Oświęcim) during World War II. Another approach, which will probably have a stronger impact, is to let the students meet history more directly by taking them on a trip to the concentration camps in the town of Auschwitz. Through such intermediaries, whether it is a textbook, a photograph, a film or the concentration camps in Auschwitz, students can face history, and not least the atrocities which happened in Auschwitz, indirectly. Although students have never seen or experienced what really happened in Auschwitz, they may be indirectly touched and affected, either in a weak or a strong sense. Such touchings may have educational effects, as students can become more aware of this specific historic event, which in turn may affect and influence their ways of thinking, and perhaps also ways of acting in the world.

Although historical events can only come to us indirectly, they can still be thought in a direct manner. This can happen by making certain goals visible to the studentsthat is, what they are expected to learn as to what happened in Auschwitz during World War II. After the goals are clarified to the students, the teacher can explain and demonstrate, as visibly and concretely as possible, what is written about the gruesome events that took place in Auschwitz in a particular textbook. The communication is straightforward, in which the teacher strives to minimise risks of misunderstandings so that the students can understand and acquire the message as directly as possible. When it comes to certain tasks that the students are expected to carry out, the teacher can clearly explain what the students should do, and how to do it, to reach the predetermined and visible goals of the specific history lesson. Overall, the teacher, through directness, wants to control the learning outcome and the future of the students.

As for educational research, indirectness can actually be a problem. The background for that assertion is that educational practice, the research object, can be examined either directly or indirectly. When the researchers make use of objectives, concepts, models and theories from the discipline of education, they think educationally. They are able to think educationally about education; meaning, they can examine educational practice directly. In such cases, the researchers do not have to take a detour or examine educational practice through other disciplines, such as sociology or psychology. However, there is a tendency to examine educational practice indirectly - that is, from perspectives beyond the educational perspective (Säfström \& Saeverot, 2017). Due to this willingness of being indirect by borrowing objectives, concepts, theories and models from external sources, outside of education, one is in danger of surrendering the educational cause (cf. Dewey, 1929). What I mean by that and which I will elaborate on through argumentation is thus: Not only will one deprive education of its autonomy, but one will also deprive the space to develop distinctive educational knowledge. This is why I 
address the following question in Chapter 6: When is it most beneficial to be indirect, and when is it most beneficial to be direct, with regard to educational research?

\section{The design of the book}

The design or plan of the book is, then, as follows. In addition to an introduction and an afterword, the book consists of seven chapters with seven different themes, where direct and indirect perspectives in education are prominent. Through observations of teaching situations, interviews with teachers and case studies of teachers and students, the book manages to draw out information and knowledge from the inside of educational practice. I also make use of cases from film, literature and art to give the reader a way into the argument.

Chapter 1 focuses on the justification of indirectness in education and attempts to address why indirectness should be part of education. Chapter 2 presents a qualitative study and has an eye on teaching in relation to both directness and indirectness. Based on empirical findings, the chapter develops four models on how and when to teach with regard to directness and indirectness. While Chapter 3 pays particular attention to different forms of indirect communication and their ethical and unethical aspects, through interviews of practitioners and thought experiments, Chapter 4 emphasises the ethics of indirect approaches by way of a case study in relation to educational practice. Chapter 5 presents a case study of 'John', a ninth-grade student, about time in relation to both direct and indirect approaches in teaching. While Chapter 6 examines educational research and its direct and indirect paths, which can have both beneficial and unfavourable consequences, Chapter 7 argues that the educational researcher can benefit from incorporating ironic indirection into the research process. Although there are connections between the chapters, it is perfectly fine to read the chapters independently, in whatever order the reader may prefer.

\section{References}

Biesta, G. (2008). Bridging the gap between educational research and educational practice: The need for critical distance. Educational Research and Evaluation. An International Journal on Theory and Practice, 13(3), 295-301.

Bollnow, O. F. (1956). Das Wesen der Stimmungen [The nature of moods]. Frankfurt:Vittorio Klostermann.

Bridges, D., Smeyers, P., \& Smith, R. (Eds.) (2009). Evidence-based education policy. What evidence? What basis? What policy? Chichester:Wiley-Blackwell.

Dewey, J. (1929). The sources of a science of education. New York: Liveright.

Hattie, J. (2009). Visible learning: A synthesis of over 800 meta-analyses relating to achievement. New York \& London: Routledge.

Hattie, J., \& Zierer, K. (2018). 10 mindframes for visible learning. Teaching for success. New York \& London: Routledge.

Kemmis, S. (2012). Researching educational praxis: Spectator and participant perspectives. British Educational Research Journal, 38(6), 885-905.

Kemmis, S., \& Edwards-Groves, C. (2018). Understanding education. History, politics and practice. Berlin: Springer. 
Maritzen, N. (2018). Was heißt und zu welchem Ende studiert man Daten? In K. Drossel \& B. Eickelmann (Eds.), Does 'what works' work? (pp. 37-54). Münster: Waxmann.

McKnight, L., \& Whitburn, B. (2018). Seven reasons to question the hegemony of Visible Learning. Discourse: Studies in the Cultural Politics of Education, 41(1), 1-13. DOI: 10.1080/01596306.2018.1480474

Nielsen, K., \& Klitmøller, J. (2017). Blinde pletter i den synlige læring. Kritiske kommentarer til "Hattierevolutionen" [Blind spots in visual learning. Critical remarks to the "Hattie revolution»]. Nordic Studies in Education, 37(1), 3-18.

Saeverot, J. (2013). Indirect pedagogy. Some lessons in existential education. Berlin: Springer.

Säfström, C. A., \& Saeverot, H. (2017). Doing harm to educational knowledge:The struggle over teacher education in Sweden and Norway. In M. Peters (Ed.), A companion to research in teacher education (pp. 179-191). Berlin: Springer.

Slavin, R. E. (2020) How evidence-based reform will transform research and practice in education. Educational Psychologist, 55(1), 21-31. DOI: 10.1080/00461520.2019.1611432

The Oxford Advanced Learner's Dictionary of English (2020). Available at: https://www. oxfordlearnersdictionaries.com (accessed 19 September 2019).

Torgersen, G.-E., \& Saeverot, H. (2015). Strategisk didaktisk modell for det uforutsette [Strategic didactic model for the unforeseen]. In G.-E. Torgersen (Ed.), Pedagogikk for det uforutsette [Pedagogy for the Unforeseen] (pp. 317-339). Oslo \& Bergen: Fagbokforlaget. 


\section{Justification}

\section{Education is indirect by nature - so what's the problem?}

The theme justification and the title of this chapter may seem confusing at first glance. It indicates that one should justify indirect pedagogy, even though education is indirect by nature. Why justify something that already exists? The thing is that indirect forms can easily take control of the teaching. Therefore I shall argue that teachers need to be aware of indirect forms which may affect the teaching and simultaneously take control of these indirect forms and turn them into educational opportunities. There is also a tendency to believe that education globally has become too one-sided directly. Teachers should, therefore, so I argue, deliberately integrate indirect elements into their teaching. With such preconditions, indirectness can be beneficial for the students.

Let me begin with the hypothesis that education is indirect by nature. For example, most of the activities that take place in schools are artificial in the sense that the teaching often occurs through indirect approaches related to society and to what we perceive as real. For instance, teachers make use of intermediaries that operate in between the teacher and the student, be it books, pictures and other sorts of learning materials to explain and define things that are happening outside the school. Instead of travelling to St. Peter's Basilica in Rome, the students may encounter this church through words, pictures and film. Nonetheless, it is a fact that in many cases, schools do attempt to shorten the distance between the students and society and real life as much as possible. This may happen through excursions to places outside the school, where students may be given opportunities to touch, smell and look at real flowers. This example shows that education can also be direct by nature, so we must not think that education is only indirect. However, education is indirect to a much larger degree than we may believe.

Why am I then proclaiming to focus more on indirect approaches in education? Is there not an adequate amount of indirect approaches in education already? The answer to these questions is twofold. Firstly, it is not just about quantity, where the focus is to implement more indirect approaches in education. One should also assess the quality of indirect approaches in education; for example, whether the indirect approach is educative or detrimental. Secondly, it would be appropriate to 
know when and in what situations one should use either direct or indirect approaches or both at the same time. Overall, the book aims at increasing the awareness of direct and indirect forms in relation to teaching (see Chapters 2, 3, 4 and 5) and educational research (see Chapters 6 and 7).

The argument in this chapter looks like this. Teachers, and everyone involved in education, should increase their awareness of intermediaries that may be involved in teaching. Such an awareness can happen through communication theory. Furthermore, teachers should not just be aware of intermediaries, but they should also strive to make them into educational means and be able to control them-as far as possible. However, it is not possible to control the intermediaries completely. One can therefore not control what kind of effect they may have on students. In fact, it is not the intention to control the intermediaries completely. The intermediaries must, to a certain extent, be released; that is, teachers must let them have an impact on the students and leave it up to the students to respond or not respond. Teachers thus move between control and non-control. The fact that teachers let go of control corresponds to risk, bold actions and permissiveness. All these actions, from awareness of intermediaries to the movement between control and non-control, are prerequisites to provide space for the educative benefits of indirectness. The chapter concludes with several examples of what such educative benefits may be.

\section{Increased awareness of indirectness through communication theory}

In terms of education, there are many different forms of indirect approach. Teachers act indirectly all the time. For example, imagine the teacher who gives praise to a student in front of the other students because the student has cleared her desk. Such praise functions as an indirect appeal to the other students in the class to clear their desks too. However, these kinds of indirect approaches often do not work very well, at least not in the long run, as children become ever more experienced and become capable of revealing such strategies. ${ }^{1}$ Another reason has to do with the fact that this strategy is indirect but yet restrictive because the teacher's intention with this form of praise is rather obvious. For that reason, teachers have several possible choices. They can choose to continue along the same track as they did before, even though their intentions keep being revealed, or they can resign and take a more direct approach. Another possibility is to continuously attempt to find new and more advanced forms of indirect approaches, with the risk of ending up manipulating children (I elaborate on this in Chapter 4). Teachers who choose this approach should aim to find "new" forms of indirect approaches (i.e., new to the child) and at the same time to increase their consciousness around these forms so that they may avoid any kind of manipulation.

The question is whether it is possible to control all intermediaries completely. If we turn to classic communication theory, the reply to the question of whether it is possible to control all intermediaries completely is that this is almost certainly impossible because there is no direct line from the sender to the receiver (Adler, Rosenfeld, \& Towne, 1996; Arnold \& Bowers, 1984; Wood, 2016). The senders cannot avoid 
indirection, as they must use one or several intermediaries. Here are some examples. First of all, the senders must turn inwards and decide what kind of message they want to communicate. Secondly, senders must choose a way to express what they wish to communicate. As for the receivers, they must be able to interpret the message being communicated and preferably in the same way that the sender intended. There are many factors and intermediaries that play a part here. For instance, there are emotions that must be coherent between the sender and the receiver to avoid any problems with their communication. Furthermore, non-verbal communication-for instance, tone of voice - plays a part. It is well-known that many children become afraid of deep men's voices and misunderstand it as a threat. Another example is when we use our intonation and tone of voice differently. To this, there is also body language: the body's position, the way we move our head, our facial expressions, our arm gestures, our eye movements and so forth. This kind of communication is complex in itself, and it is a challenge in relation to communication. In addition to all of this, things are even more complicated when we take into consideration the various combinations of forms of intermediaries the sender can use.

It is possible to claim that a message must go through many intermediaries and that the probability of being able to control all of these intermediaries is minimal. Furthermore, it is also possible to claim that being pedagogical means to be distinct and to deliver a clear message; that is, one should attempt to control as many intermediaries as possible, even though it is not possible to control them completely. Even modern curricula, which have been heavily criticised because of their distinct learning objectives (Deng, 2018; Priestley \& Minty, 2013), cannot live up to a form of direct pedagogy that can control the teaching situation completely. The relationships between the teacher and the student are inherently indirect. We might believe that education happens in a direct fashion, but that is because we are deceived by simple explanations of reality, which is always more complex than we imagine and therefore very difficult to describe in words (Roberts \& Saeverot, 2018).

Furthermore, when we use indirect approaches, we can never be sure what the result will be. It is not in the power of the teacher to control the end result, at least not completely. Both outcomes and end results are much easier to control by way of direct instructions. That is perhaps one major reason why directness has become a huge part of the visible learning paradigm (Terhart, 2011). By controlling the intermediaries, teachers may be able to ensure a direct line between the teaching and the student. By taking as many precautions as possible concerning the various intermediaries in teaching and learning, unlike in a more indirect form of pedagogy, teachers can to a relatively large extent achieve what they planned beforehand (Biesta, 2014; Lewis, 2018).

Communication theory shows that there are a number of intermediaries involved in the communication between a sender and a receiver. Since communication is part of the teaching, insight into communication theory can make teachers aware that they are subject to a number of intermediaries which cannot be fully controlled. But still, even if one cannot control the intermediaries completely, teachers should strive to control them as best they can while consciously creating space for intermediaries. Let me elaborate on this. 


\section{Being indirect, yet controlling the intermediaries}

To be pedagogical may in the perspective provided earlier be perceived in two ways. One can be pedagogical in the traditional sense, and that corresponds to minimising and controlling intermediaries and communication noise in the best possible way so that the information can be as clear as possible for the receiver. An example of this is to use short sentences, speaking slowly and clearly, while minimising the use of gestures and body movements. Another way to be pedagogical is to consciously make use of various intermediaries in teaching and then leave it to the receiver to interpret, respond, etc. Instead of trying to minimise the intermediaries and trying to control them completely, the teacher creates space for intermediaries while at the same time trying to control them to a certain degree.

We can take a closer look at how a teacher may use intermediaries while trying to control them through the following example. Let us imagine that the teacher has taken the class to an art exhibition. The teacher knows that one of the students has a big interest in cars, particularly race cars. In the distance, the teacher sees an art picture with a red Ferrari and starts to point in the direction of the art picture while he says, "Look, a race car!" The teacher's intentions are good. He wants to create a direct connection between the boy and the art picture. However, it is arguable that the teacher has appeared as an unnecessary intermediary between the art picture and the boy, as he has blocked the moment of surprise and the boy's feeling of having seen the picture himself.

Another way to do this is as follows. Once the teacher sees the picture of the race car, he can discreetly make sure to change the walking direction of the student so that he can have the pleasure of discovering the artwork himself. Changing the walking direction of the student can be done physically. For example, the teacher can position himself in such a way that the boy is forced to walk towards the art picture. No matter how it is done, the teacher must act; however, the intention of this action remains invisible to the student. The intermediary in this situation is the teacher's discrete change of the boy's walking direction. By way of this controlling of an intermediary, the art picture can touch the boy directly, without having to take a detour via the teacher as was the case in the first example. "Did you see that race car?" asks the student with excitement. "Yes," says the teacher and pretends that he only saw the art picture after the boy made him aware of it, so he does not spoil the boy's excitement and pleasure of having discovered the pictured race car. The teacher plays a role by pretending that he did not see the artwork before the student made him aware of it (cf. Burbules \& Rice, 2010), hence we might call this act "the pious deceit of education."

So far this is an initiating phase of education. What I mean by that is that the student, thanks to the teacher's indirect act, is faced with a picture that interests him. The teacher now has an opportunity to follow up with questions and viewpoints that may be educative for the student.

Making space for intermediaries means knowingly staging and arranging various indirect elements in situations involved in teaching. Here is another example. A student in elementary school is working on a project that she will present in two 
weeks. She is very excited and happy with her own work effort and shows the teacher what she has achieved as if she has finalised the whole project. The teacher may of course respond in several ways. One response may take the form of praising the student and emphasising that her work is very good. Alternatively, the teacher can choose to emphasise that the student needs to work more since there are two more weeks until the presentation of the project. A third approach is to let praise, criticism and summoning interact dialectically, thus, "This is very good; you have come this far, even though there are two weeks until the presentation."

If we start by looking at the first reaction, where the teacher praises the student, the problem is that the teacher submits to the student's enthusiasm over her own work efforts. Thus, important learning leading up to the performance in two weeks may not happen. The teacher's positive response confirms the student's satisfaction with her work effort, and she might not put more work into the project over the next two weeks. The second response, where the teacher emphasises that the student must work more, corresponds to a direct summoning. The problem here is that the student has to submit to the teacher's will; hence, there is a danger that the student's enthusiasm and interest in the assignment may decrease.

In the third approach, the teacher makes use of three intermediaries which function as educational means - that is, praise, criticism and summoning in one and the same sentence. The teacher also tries to control these intermediaries as well as possible. By starting with praise ("this is very good"), the teacher tries to keep the student's enthusiasm and interest in the task. Thereafter the teacher conducts an indirect critique ("you have come this far"). The teacher also tries to control this intermediary by striving to keep the student's enthusiasm and interest while gently implying that she needs to put in more work. Notice that "this far" means that she is not finished; rather, she is in the process. Instead of resorting to direct criticism (e.g. "this is not good enough, you have to work harder"), the teacher resorts to indirect criticism which gently suggests that the student has not finished the task and that more work remains to be done. In the indirect critique, therefore, there is also a cautious summoning, which is clarified somewhat more in the third part of the sentence ("even though there are two weeks until the presentation"). The indirect criticism thus evolves more into an indirect summoning in the last part of the sentence, which implies that the student should work more on the assignment towards the performance in two weeks.

Although the teacher tries to control the intermediaries and uphold the student's enthusiasm and interest in the task, while encouraging the student to put in more work, there is an element of risk here. The risk occurs as the teacher lets the student choose if/how she will respond to the teacher's response. It is therefore conceivable that the student does take into account the indirect criticism and indirect summoning, but it is also conceivable that the student chooses not to. Let us have a closer look at the element of risk.

\section{Bold actions and permissiveness}

As I stated earlier, teachers, as they try to control the intermediaries as best they can, must also let go of control. This means that teachers must, to a certain degree, 
release the intermediaries. In this way, indirect pedagogy can be considered a bold action. It is a bold action because the result of the pedagogical action is impossible to calculate in advance. The result of the action can exceed by far what the teacher had imagined in advance. This is especially true in cases where the teacher has put together many indirect elements. In such cases, it can be extremely hard to predict the consequences of the actions.

At the same time, there is a form of permissiveness in this indirect form of pedagogy, in the sense that the permissiveness can allow the students to become more attentive and also to become more aware of the goings-on in the world and in their own lives. To be permissive in this sense is not the same as having no authority. There is a certain authority in the fact that the teachers slightly lead the attention towards something, for instance by showing little glimpses of a certain mode of existence by way of their teaching. Nonetheless, the authority is at the same time loosened by the fact that the teachers manage to render themselves superfluous. This way, the students do not feel that the teacher is governing them at all times. Such a feeling might cause the students to become so preoccupied with the teacher's opinion that their own ability to make independent decisions is completely paralysed (Kohn, 2018). To prevent this from happening, teachers might conduct an indirect move to make the material or the content as interesting as possible, and thereby raise awareness and expanding choices without meddling with the student's decisions. I elaborate on this in Chapter 3, in particular in the section where I argue for the teacher as a nobody.

So far, we have seen that intermediaries are involved in teaching, whether teachers want them to be or not. In an educational light, this means that teachers must try to control the intermediaries, which can easily take control of the teaching. However, it is virtually impossible to gain full control over the intermediaries. Nevertheless, some control is needed so that the intermediaries do not have free rein, as they can actually harm the students (we will look at this in more detail in Chapters 3 and 4). Not only should teachers, so I have argued, strive to turn the intermediaries that are part of teaching into educational means, but they should also plan and stage intermediaries in their teaching. Thus teachers take control of the intermediaries, but at the same time as they do take control, they should also let go of control in order for the intermediaries to have an impact on the students, who must always be given the opportunity to respond freely or not respond at all. These are prerequisites that can help make the intermediaries becoming educationally beneficial.

\section{Examples of beneficial uses of indirectness}

What has been argued so far also raises a number of questions. One of these questions is about the claim that teaching is indirect by nature, as teachers are more or less forced to relate to intermediaries that cannot provide direct or clear pathways. These intermediaries bring a lot of complexities to the table. So would it not be wiser to attempt to lessen the use of indirect actions as much as possible instead of planning and staging indirect elements in teaching? At times, yes. There are times when teachers need to be as direct as they can be. But there are also times when 
teachers need to be indirect, and that is because certain situations can enforce indirect approaches. Furthermore, indirect approaches of various kinds can work better than, or be more beneficial than, direct statements in many cases. I have already given some examples of this earlier in the chapter related to specific education situations and purposes, and I will give several concrete examples of this in the chapters that follow, but before I do so, here are some examples that show certain benefits of being indirect. These examples are, among other things, taken from film and literature and have elements of education in them.

Reducing tensions. Let us imagine a group of students who are challenging to teach. It is one of the usual situations that we often hear about: lots of noise, disruption and a lack of discipline. The teacher has been trying in vain to talk sense into the class by lecturing them, trying to appeal to them, criticising them and so on. In spite of the teacher having tried almost everything, the two parties (the teacher and the students) are now in conflict with each other. There could be many explanations as to why this situation has occurred. One explanation could be that the teacher has been too direct in his approach to the problem. That is to say that the teacher has constructed an image of the class in his mind in which they are noisy and undisciplined, and the teacher has forwarded this image, perhaps unconsciously, to the class. The students are thus seeing themselves directly as they "are," or, more precisely, the way the teacher sees them. Such images can feel like an overarching assertion of power to students, and they may naturally defend themselves by striking back. In spite of the teacher's wish to make the class more calm, we may in this case talk about a self-fulfilling prophecy because the students will uphold their level of noise, or even pull it up a few notches, simply because the teacher has made them aware that they are noisy, undisciplined and uncontrolled.

Metaphorically speaking, we end up with two magnets with positive poles pulling away from each other, no matter how much effort is made to try to push them together. That is why the teacher needs to act like a magnet with a negative pole, meeting the students' positive pole so that they can come closer to each other. The teacher must take a negative or indirect approach. One form of indirect approach in this case would be to use humour to reduce tensions, while creating a congenial atmosphere (Banas, Dunbar, Rodriguez, \& Liu, 2011; Jeder, 2015; McCreaddie \& Harrison, 2019, pp. 295296; Raskin, 2008). I return to humour as an indirect form of pedagogy in Chapter 3.

Arouse reflection. When matters are complicated, it can be almost impossible to speak about them in a direct manner. This leaves us with no other choice than to speak indirectly. The Wannsee Conference in Berlin in 1942 provides an example of this. At this conference, a group of Nazis discussed the "Final Solution" to the "Jewish Question." Certain parts of what happened at this conference were dramatised in Frank Pierson's film Conspiracy (Pierson, 2001), in which the character based on Friedrich Kritzinger (1890-1947) is the only person who is opposed to the suggestion of eradicating all Jews once and for all. ${ }^{2}$ As a way of warning the Germans of what they would face if they executed such a terrible plan, Kritzinger tells a story to the character based on Reinhard Heydrich (1904-1942), who then retells the story to those who portray Adolf Eichmann (1906-1962) and Rudolf Lange (1910-1945). 
HEYDRICH: He told me a story about a man he had known all his life, a boyhood friend. This man hated his father. Loved his mother fiercely. His mother was devoted to him, but his father used to beat him, demeaned him, disinherited him. Anyway, this friend grew to manhood and was still in his thirties when the mother died. The mother, who had nurtured and protected him, died. The man stood at her grave as they lowered the coffin and tried to cry, but no tears came.

The man's father lived to a very extended old age and withered away and died when the son was in his fifties. At the father's funeral, much to the son's surprise, he could not control his tears. Wailing, sobbing...he was apparently inconsolable. Utterly lost. That was the story Kritzinger told me.

EICHMANN: I don't understand.

HEYDRICH: No?

EICHMANN: ...

HEYDRICH: The man had been driven his whole life by hatred of his father. When his mother died, that was a loss, but when his father died and the hate had lost its object, the man's life was empty. Over.

EICHMANN: Interesting.

HEYDRICH: That was Kritzinger's warning.

Kritzinger's story can be viewed as a warning and a desperate last attempt to educate his Nazi colleagues. Indirectly, his message proclaimed something like this: "Do not let your lives be filled with so much hate that when that hate is gone, there is nothing left to live for." Through an indirect approach, Kritzinger created a sort of futuristic scenario and possible consequences that the receivers could imagine in their minds. Unfortunately, as we know, Heydrich and the other Nazis could not be persuaded.

Protecting oneself. Another example could be a Norwegian person suddenly speaking in English when they meet another Norwegian person, saying words such as "I miss you" or "Love you" in English. This person is speaking in an indirect way via a different language because it feels too strong to say this through the mother tongue. This way you can secure a certain distance to what you want to express, as a way of protecting yourself. How can this be transferred to education situations? For example, it may be appropriate to replace certain words or express oneself somewhat differently when it comes to strong and controversial topics (e.g. abuse, racism, genocide) as a way of protecting the students. Teachers should also be aware that students can do similar things because it signals that the students wish to protect themselves.

Achieving justice. Yet, many will claim that there is something unethical about an indirect approach (as we shall see in more detail in Chapter 4). And some may add that it is more honest and fair to say things as they 'really are.' Such claims ignore the fact that an indirect approach can sometimes be the only way to achieve justice. This claim can be substantiated by way of Steven Spielberg's film Schindler's List (Spielberg, 1993). On several occasions, the main character, based on Oskar Schindler (1908-1974), who is often regarded as being a highly ethical man, is forced into an indirect approach. In the movie, he is deeply affected by seeing the 
Nazi, based on Amon Leopold Göth (1908-1946), shooting random passersby from his porch. How could Schindler stop Göth from killing these innocent people? How could Schindler educate Göth? Could he have said directly to Göth that he should stop? Yes, he could, but it would most likely have been very dangerous. He would probably just have egged Göth on and at the same time turned him against himself. Schindler seems to predict that, and thus he chooses to take a detour through cunning and deceit. At first, he has to get to know Göth to find out what his motivation is and what matters to him. Schindler concludes that the answer is power, and on one occasion he says to Göth, "Power is when we have every justification to kill — and we don't." In this manner, by redefining the concept of power, Schindler indirectly tells Göth that he should stop shooting innocent people. Schindler can thereby educate Göth indirectly and turn him away from killing innocent people.

Being polite and humble. Indirectness is not a new phenomenon. It has probably always been a part of our languages. A good example of indirectness can be found in a work written about 800 years ago. I am thinking of the Old Norse Kings' sagas or Heimskringla, probably written by Snorri Sturluson (1179-1241) in Iceland in the 1220s. We find a concrete example of the use of indirectness in Chapter 190 of the Saga of St. Olaf.

It so happened one Sunday that King Olaf sat in his high seat at table, and was in such deep thoughts that he was unaware of the lapse of time. He had a knife in his hand and cut chips from a piece of wood. The page stood in front of him with a goblet and saw what the king was doing, and thought that he was thinking of other matters. "It's Monday tomorrow, sir," he said.

(Hødnebø \& Magerøy, 1996, p. 83; my translation)

Although modern education goes beyond the Christian form of existence, we must look at the passage from a Christian perspective, as Saint Olaf, without being aware of it, forgot to rest on a Sunday. The page does not say directly to Olaf that it is Sunday; rather, he acts indirectly by reminding the king that it is Monday tomorrow. There may be several reasons why he chooses to communicate indirectly in this way. One of the reasons has most likely to do with the fact that it is the page, a servant, who actually educates the king himself, and that can be dangerous. We can therefore assume that the page chooses to act indirectly as he fears negative consequences by saying directly that the king works on a Sunday. At the same time, the page's indirect expression signals reverence and respect. While a direct command risks humiliating the king, push him up against the wall so to speak, the indirect way of communicating gives the king a way out; hence, he avoids losing face.

Making space for multiple exits. The previous examples show that indirect communication, unlike direct communication, has the advantage that it can give the other party multiple exits, hence minimising the risk of being humiliated. For example, Schindler is able to turn Göth away from killing innocents, but not in such a manner that Göth loses face. Göth is given a way out; he can continue to 
use his power to pardon Jews and others so that no one is killed or physically harmed. King Olaf, too, is given a way out by the page. An indirect expression, if used in a constructive way, is like a foxhole with multiple exits (and entrances too).

\section{Summing up}

The hypothesis that education is indirect by nature was the point of departure of this chapter. The question was raised whether it is possible to be direct in teachings and other educational actions, given the fact that communication is highly complex, involving a number of intermediaries which operate in between teachers and students. I then went on to provide examples of intermediaries - e.g. emotions, non-verbal communication and body language - all of which prevent a direct line of communication between the teacher and the students. Teachers, so I argued, are forced to act indirectly via a number of intermediaries. Only when we command others do we become somewhat direct. However, the command leads us to the far end of the scale of communication, a scale with different degrees of directness and indirectness. At the far end of the scale, the command is directed towards a will that is not free, one that is not given any choice, e.g. "Sit!" or "Keep your mouth shut!' It is nearly impossible not to understand these kinds of commands because there are no intermediaries present to disrupt the interpretation. That is also the reason why commands generally are not a part of education, as education relates to individuals with free will.Yet, education is often associated with clarity and explicitness in terms of communication and teaching. Direct or explicit instruction is a good example of that. In certain teaching situations, such instructions can be beneficial, but as soon as matters without clear answers and objectives enter the educational sphere, more indirect forms of communication and action are required. Teachers then need to make room for intermediaries to open up for choices for the students. Such acts involve risks as the chances of failure are possible, yet risks are necessary to allow students to respond from their own personal perspective or from a firstperson standpoint (Biesta, 2014; Bollnow, 1976; Mooney Simmie \& Moles, 2020). To provide such a free space, a form of indirect approach is required.

\section{Notes}

1 This is a hypothesis that needs to be examined.

2 Whether or not Kritzinger opposed the Wannsee Protocol remains uncertain.

\section{References}

Adler, R. B., Rosenfeld, L. B., \& Towne, N. (1996). Interplay: The process of interpersonal communication. New York; Harcourt Brace.

Arnold, C. C., \& Bowers, J.W. (Eds.) (1984). Handbook of rhetorical and communication theory. Boston: Allyn \& Bacon.

Banas, J. A., Dunbar, N., Rodriguez, D., \& Liu, S.-J. (2011). A review of humor in educational settings: Four decades of research. Communication Education, 60(1), 115-144. DOI: 10.1080/03634523.2010.496867

Biesta, G. (2014). The beautiful risk of education. Boulder, CO: Paradigm Publishers. 
Bollnow, O. F. (1976). Eksistensfilosofi og pedagogikk [Existentialism and education]. Copenhagen \& Oslo: Christian Ejlers' forlag.

Burbules, N. C., \& Rice, S. (2010). On pretending to listen. Teachers College Record, 112(11), 2874-2888.

Deng, Z. (2018). Contemporary curriculum theorizing: Crisis and resolution. Journal of Curriculum Studies, 50(6), 691-710. doi:10.1080/00220272.2018.1537376

Hødnebø, F., \& Magerøy, H. (Eds.) (1996). Snorres kongesoger, 2 [Snorre's Kings' sagas, 2]. Oslo: Det Norske Samlaget.

Jeder, D. (2015). Implications of using humor in the classroom. Procedia - Social and Behavioral Sciences, 180, 828-833. doi:10.1016/j.sbspro.2015.02.218

Kohn, A. (2018). Punished by rewards: Twenty-fifth anniversary edition: the trouble with gold stars, incentive plans, A's, praise, and other bribes. Boston \& New York: Mariner Books.

Lewis, T. (2018). Inoperative learning. A radical rewriting of educational potentialities. New York \& London: Routledge.

McCreaddie, M., \& Harrison, J. (2019). Humour and laughter. In O. Hargie (Ed.), The handbook of communication skills (pp. 287-317). New York \& London: Routledge.

Mooney Simmie, G., \& Moles, J. (2020). Teachers' changing subjectivities: Putting the soul to work for the principle of the market or for facilitating risk? Studies in Philosophy of Education, 39(4), 383-398. https://doi.org/10.1007/s11217-019-09686-9

Priestley, M., \& Minty, S. (2013). Curriculum for excellence: 'A brilliant idea, but.' Scottish Educational Review, 45(1), 39-52.

Raskin, V. (Ed.). (2008). The primer of humor research. Berlin: De Gruyter.

Roberts, P., \& Saeverot, H. (2018). Education and the limits of reason: Reading Dostoevsky, Tolstoy, and Nabokov. New York \& London: Routledge.

Terhart, E. (2011). Has John Hattie really found the holy grail of research on teaching? An extended review of Visible Learning. Journal of Curriculum Studies, 43(3), 425-438.

Wood, J.T. (2016). Interpersonal communication: Everyday encounters. Boston: Cengage Learning.

\section{Films}

Pierson, F. (Director) (2001). Conspiracy (motion picture).

Spielberg, S. (Director) (1993). Schindler's List (motion picture). 


\section{Teaching}

\section{Four forms of teaching. Excerpts from observations at a secondary school}

The theme of this chapter is teaching. By way of classroom observations and teacher interviews at a secondary school, we shall take a closer look at different forms of direct and indirect teaching and examine when, or in what situations, teachers made use of direct and indirect approaches in their teaching. We shall also look into which fields, such as epistemology, morality and existence, and perspectives, either first-person or third-person perspective, the different forms of direct and indirect teaching were connected to. This way we can get a clue as to when it is most appropriate to use direct and indirect approaches in teaching.

\section{Introduction}

The background for the study is that racism, anti-Semitism, xenophobia, discrimination and the like appear among parts of the population in Western Europe, in the form of prejudice negative emotions and hostile attitudes which exclude others (CNCDH, 2018; HL-Center, 2012; Hoffmann \& Moe, 2017). While a democracy is characterised by inclusion (Irigaray, 2001), these referred studies reveal exclusion towards individuals or groups of people. Such exclusiveness can therefore be termed "undemocratic attitudes." Why is this exclusion of others happening? Is it something society just has to expect, that certain people embrace undemocratic attitudes? Or can schools prevent and avert the formation of such attitudes? Can such attitudes also be removed, a kind of process of unlearning (Baldacchino, 2019)? It is difficult to answer the questions unequivocally, as it is almost impossible to know what it is that removes undemocratic attitudes and prevents the formation of undemocratic attitudes. It may be that the schools contribute in doing so, but other factors may also contribute. Nonetheless, the schools' social mandate requires to do what it takes to remove undemocratic attitudes and prevent such attitudes from becoming part of the students' existence and way of life. What can schools do then to remove, and prevent the formation of, undemocratic attitudes?

A theoretical assumption is that the achievement of the double purpose of education (see introduction) will remove undemocratic attitudes and prevent these attitudes from becoming part of the student. As for the purpose related to the individual 
perspective, different qualities are prominent, e.g. freedom, independence and critical reflection (Biesta, 2014; Dewey, 1998). In addition, the term 'self-activity' (in German: Selbsttätigkeit) is relevant in this context. The German philosopher Johann Gottlieb Fichte (1762-1814) gave rise to the notion of self-activity, which is related to pedagogy as an action consisting of "summoning to self-activity" (in German: Aufforderung zur Selbsttätigkeit) (Benner, 2012). More specifically, this can be understood as a first-person perspective in that the teacher summons students to work or act on an independent basis (Benner, 1995, pp. 21-22).

In addition to the individual's self-activity and the unfolding of individuality, the double purpose of education relates to morality, responsibility, solidarity and humanity (Klafki, 2001, pp. 36-37; Stojanov, 2018; Rucker, 2020). The goal of such teaching is to prepare students to live in a society, whether large or small, in interaction with other people and in line with current democratic principles (Dewey, 1966; Heitger, 2004). Furthermore, the individual will be initiated in values and norms, traditions and cultures and the like (Saeverot \& Biesta, 2013). In this way, the double purpose of education is a form of cultivation in which the initiation of the individual to cultural values, morals and societies is at the centre of the formation-oriented teaching activity (Meyer, Meyer, \& Ren, 2018; Peters, 2007). This is a third-person perspective in which values and norms, tradition, culture and society function as the "third person" whom the cultivated individual is guided by.

However, the educational purpose associated with the world involves more than initiation and cultivation. As part of the purpose, each individual should be able to take personal responsibility towards others, in addition to ready-made norms and rules or what the individual has been initiated into in terms of such categories as morality, empathy and solidarity (Benner, 2012, p. 78ff.). Thus, the first-person perspective is also applicable in this context, as the double purpose of education implies that individuals act ethically and morally on their own free will (Biesta, 2014; Reichenbach, 2011; Uljens \& Ylimaki, 2017).

Since the theoretical assumption signifies that the achievement of the double purpose of education will remove undemocratic attitudes and prevent these attitudes from becoming part of the individual, one may ask in a normative and generalised manner, How can one teach to achieve this double purpose? The fact is that there is not one particular way of teaching that will achieve the double purpose of education. One can of course argue for either this or that way, but such an approach will in any case give us nothing but a theoretical assumption. Moreover, we must not forget that the double purpose of education is an ideal that probably will never be fully achieved in practice.

What we can do though is to locate the double purpose of education in a concrete teaching situation. As such, we stand before a descriptive problem or research question, reading thus, How do teachers teach to ensure that each individual can live well in a world worth living in? If we contextualise this question, we may ask, How do teachers teach to remove undemocratic attitudes and prevent the formation of undemocratic attitudes in secondary school? As such, we will obtain something more than just a theoretical assumption, but still, we will at most only receive a glimpse, and certainly not a full answer, as to how teachers teach to remove and prevent the formation of undemocratic attitudes. 
To address this latter question, the research team, consisting of two educational researchers and myself as the project manager of the project, had to enter classrooms and observe teachings in which issues related to undemocratic attitudes were prominent. As a first step, we established collaboration with two teacher groups at a Norwegian secondary school. The first teacher group related to the subject of social science (eighth grade), and the second teacher group related to the subject 'knowledge of Christianity, religion, philosophies of life and ethics' (KRLE) (tenth grade). This collaboration included two start-up meetings, observation and sound and film recordings of teaching sessions, as well as group interviews with two different teacher groups about the teaching which had been filmed and observed. This group interview and the conversations were specifically concerned with the research question, as well as the planning, implementation and evaluation of the teachings. The group interviews were used as a corrective source for the observations of the teachings (cf. Kvale \& Brinkmann, 2009; Wengraf, 2001). In the first meeting, we discussed possible educational actions related to the double purpose of education, including ways to remove and prevent the formation of undemocratic attitudes. The goal was to have a mutual understanding of the main concepts and ideas of the study.

Secondly, the teacher groups planned a teaching session separately on a topic they wished to explore through their teaching. The teacher groups and the research team had already agreed that the chosen topic should be connected to undemocratic attitudes. Thus, within a predetermined framework, the teachers could choose a topic that was relevant and useful to the students and the goals of the school (cf. Creswell, 2014; Mason, 2002). The teacher group that I am mostly concerned with in this chapter related to the subject of social science, and they chose power as their topic for teaching. Next, the teachers sent us their planning forms as preparation for the observation and the sound and film recordings of their teaching. In addition to the recordings, the research team wrote field notes for documentation (cf. Creswell, 2013; King \& Hornberger, 2010). The empirical material in the study is thus collected by way of field notes, interviews, observations and sound and film recordings of teaching lessons at a Norwegian secondary school. The teachings in the double lesson in social studies were conducted by one teacher while the other teachers in the group observed the actions.

In the following, I will bring the reader through the necessary steps, from analysis to findings, and finally to discussion and conclusion.

\section{Categories of analysis}

The sound and film recordings were transcribed, after which the data material from the teaching lessons was repeatedly studied and systematised based on three theoretical models for direct and indirect pedagogy, or three forms of teaching, i.e., direct instruction (DI), indirect summoning which is specified (ISS) and indirect summoning which is unspecified (ISU; Saeverot, 2017). In other words, the three models were used as categories of analysis. Let me henceforward present the models. 


\section{Direct instruction}

As I pointed out in the introduction, a trend in modern education is the so-called visible learning paradigm (Nielsen \& Klitmøller, 2017, p. 3). Since the publication of the book Visible Learning: A Synthesis of over 800 Meta-analyses Relating to Achievement in 2009, John Hattie has had a major impact on Western education (Terhart, 2011). Hattie's book on visible learning consists of a synthesis of over 800 meta-analyses, of which more than 52,637 individual studies are integrated. Although Hattie's book consists of a vast empirical material, he also finds support from certain theoretical assumptions on what learning and teaching signify. One of Hattie's projects has been to develop a theory of what good teaching is. At the heart of Hattie's learning and teaching model, we find, as stated in the introduction, the term 'direct instruction' (Hattie, 2009).

A typical feature of DI is to show students what to do and how to do it. A way of doing so is to clarify goals in advance of the teaching so that the students can know exactly what is expected of them in terms of learning. Not least, the teachers are direct, explicit and as concrete as possible in their communication to the students. Clear explanations, descriptions and illustrations are given of that which is being taught. One of the goals of DI is to avoid misunderstandings while ensuring that the reception and interpretation of the content of the teaching become as easy as possible for the students. Therefore, the information and knowledge being taught are well structured in order for the students to learn that which the teacher communicates and disseminates (Figure 2.1).

As the model illustrates, DI is strongly teacher-driven. DI is therefore a thirdperson perspective, as the teacher points out the directions of the students, who in turn must trust the teacher's directives and guiding instructions. Learning different skills is at the centre of the model.

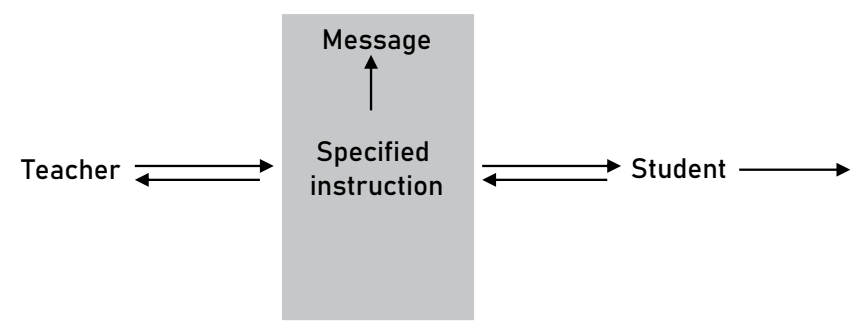

Figure 2.I Model for DI (Saeverot, 2017). The figure shows a teaching situation and a communication relationship between teacher and student. Left: The teacher conveys a message to the student. Middle: The message takes the form of a specific instruction, i.e. the teacher is explicit as to how the student shall relate to the message. This means that the teacher provides a clear direction for the student. Right: The arrow at the far right of the figure illustrates that the student basically only has one choice, which is to follow the direction pointed out by the teacher. The two arrows that proceed from student to teacher illustrate the student's response to the teacher. 
Beyond this direct form of teaching, the double purpose of education implies teaching that is indirect, which may be both third-person oriented and first-person oriented. A first-person perspective of the double purpose of education, regarding both the individual and the social side of this purpose, does require an indirect approach (Saeverot, 2013, 2017). That is to say, if you wish someone to respond independently of a third person (e.g. a teacher) you cannot point out the answer beforehand; instead, you need to be indirect in ways that you find valuable in the particular situation (Saeverot, 2017). In education, there are several forms of indirect teachings, which can be divided into two main groups (ibid.). Let us look into these two groups.

\section{Indirect summoning which is specified}

The first group or form of teaching is referred to as ISS (Saeverot, 2017). A concrete example of ISS is the teacher who praises one of the students publicly in the class for having acted morally according to certain criteria and standards. As I pointed out in the introduction, such a form of praise communicates indirectly to the other students, who are indirectly summoned to act morally in the same or similar way as the student being praised. Actually, the teacher has acted indirectly in two ways. Firstly, the teacher has made a detour through an intermediary, which in this case is one of the students (who is praised), rather than communicating directly to the whole class. Secondly, the teacher has 'wrapped the message' by highlighting the 'good' behaviour of one of the students rather than saying directly that the other students may not have acted satisfactorily according to certain moral standards (Figure 2.2).

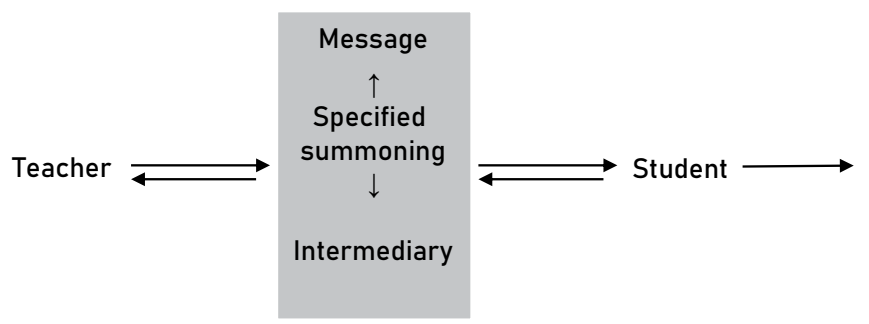

Figure 2.2 Model for ISS (Saeverot, 2017). The figure shows a teaching situation and a communication relationship between teacher and student. Left: The teacher conveys a message. Middle:This message goes through an intermediary, e.g. a fellow student. Even though the message goes through an intermediary, the message summons specifically how it should be received by the student (or group of students). That is to say, the teacher is rather explicit as to how the student should respond to the message. Despite the fact that the message goes through an intermediary, the teacher provides a clear direction for the student. Right: The arrow at the far right of the figure illustrates that the student basically only has one choice, which is to follow the direction pointed out by the teacher. The two arrows that proceed from student to teacher illustrate the student's response to the teacher. 
Although the teacher in this example is indirect, the teaching must be considered a third-person perspective, as the student's choices are neither free nor independent of the teacher as a third person. Furthermore, the teacher's summoning is specific even though it is not specified in words; that is, the teacher makes use of an example, specific words and perhaps also body language as a way of guiding and directing the students. This indirect summoning, which is specific, is therefore strongly teacher-driven and based on a relatively strong desire for control.

\section{Indirect summoning which is unspecified}

The other group or form of teaching which is indirect is referred to as ISU (Saeverot, 2017). A concrete example of ISU is teacher students who train to become teachers. Teacher students train to work in educational practice contexts and must therefore presuppose the indefinite child existing in an open and unforeseeable future. Educational practice is therefore highly unpredictable, compared to a craftsman's practice, e.g. a plumber. Thus one should not teach a teacher student to become a full-fledged teacher in the same way as one teaches a plumber student to become a full-fledged plumber. Faced with teacher students, one must take into account that educational practice is unpredictable by nature (I elaborate on this in Chapter 7). For this reason, it is not beneficial to say specifically and directly what the teacher students should do before they enter educational practice. It will be like trying to seize time before it arrives, but that is simply not possible (the concept of time will be elaborated on in Chapter 5). Therefore, teacher educators should, to a rather great extent, be indirect in their teaching of teacher students. For example, this can be done by using moral examples from educational practice, examples that make room for reflection, which may enhance the students understanding and awareness of moral issues in educational practice.

Since the teacher educator in this example does not summon anything predetermined and specific through the indirect teaching form, the teacher students are free to respond to the example regardless of what the teacher educator might think of the matter. In this way, ISU is categorised as a first-person perspective, as the students must trust themselves, involving self-trust rather than relying entirely on the teacher as a third person (Figure 2.3).

Praise given indirectly, e.g. by way of criticism, is another example of ISU (Saeverot, 2011). This kind of indirect praise also creates space for the recipients' freedom, as the one who hands out criticism, through which praise appears indirectly, does not summon or call upon anything specific. Instead of praising someone directly, criticism may be used, that is, a form of criticism which communicates indirectly that the recipient's act or behaviour, or whatever it might be, is being credited as valuable, in addition to the criticism. Thus, the recipient has greater freedom and a more open choice when it comes to responding to such a form of indirect praise compared to direct praise which more clearly indicates and specifies the direction of the recipient's response.

ISU, in contrast to DI, also provides multiple exits for the recipients. This is important, as recipients may be locked or trapped when there is only one way out. Let us return to the example of Schindler and Göth in Chapter 1. In order 


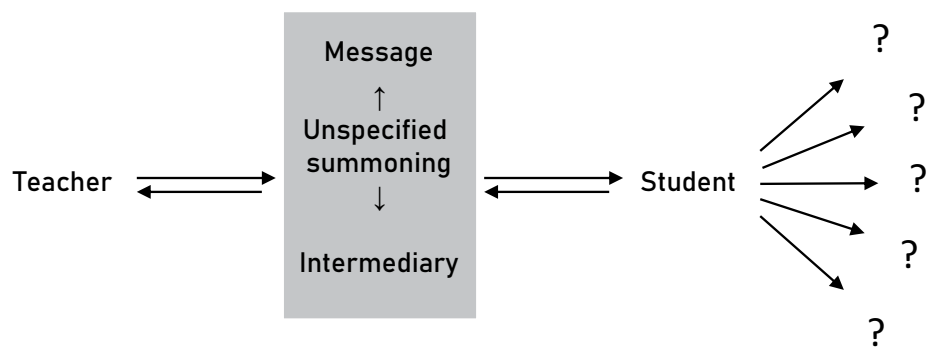

Figure 2.3 Model for ISU (Saeverot, 20I7). The figure shows a teaching situation and a communication relationship between teacher and student. Left: The teacher conveys a message. Middle:This message goes through an intermediary, e.g. praise by way of criticism. The message, which goes through an intermediary, does include a summon, but the summon is unspecified. That is to say that the teacher is open as to how the student should respond to the message. This is how the teacher makes room for choice. How to respond is up to the student, who may also choose not to respond. Right: The arrows and the question marks at the far right of the model illustrate that the student may respond in more than one way. The two arrows that proceed from student to teacher illustrate the student's response to the teacher.

for Göth not to lose face, Schindler created space for exits. Thus, Göth could get out of the situation with his head held high. In fact, it was a win-win situation for both the communicator and the receiver, as Schindler also gave himself numerous exits. Another example is when the teacher has to mediate between two students, where one student has done something wrong to the other. How many times have we not seen adults forcing children to shake hands and apologise? In such cases, no exits are provided, and the danger is that at least one of the students will be humiliated or embarrassed. Besides, the handshake is directed by a third person; namely, the teacher. It may therefore be appropriate to be indirect so as to let the students solve the situation on their own initiative. The students are then given many exits. They may not have to apologise directly or because someone is telling them to do so. Even though they may not apologise at all, they are summoned to apologise indirectly. Such apologies can take on different forms, e.g. through bodily expressions shoving regret, laughter, making jokes, change behaviour towards the other, etc. When teachers act indirectly in such situations, where responsibility towards others is at the centre of the education, the students may not feel that they are indebted to each other.

\section{Findings}

\section{Direct instruction}

The analyses of the social science lesson show that the teacher gave DI both to the students individually and in groups. For example, the teacher said the following at the start of the lesson: 
The teaching henceforth will be about 'power.'The first thing to do then is to open your books, and write for two minutes, completely on your own. You shall not talk to each other; rather, you shall write individually for two minutes what you associate with the word power. From now on.

The example shows a DI as to what the students should do individually. The findings also show examples of DI as to what the students should do in groups. Teacher: "Now you all have to listen well to what the groups say." During the social science lesson, the teacher also gave DI related to academic requirements. For example, the students were asked to make their own definition of the term 'power,' while the teacher added: "A definition is a short sentence that says what something is." In this way, the teacher explained directly what was meant by defining a term. What he did was to give the students knowledge in the form of conceptual understanding before they started to define the term power.

Similar DI in connection with students at both an individual and a group level, alongside requirements for academic results, were revealed in the KRLE lesson. After the teacher gave instructions regarding group work, he gave the following message to the students: "Initially, you will receive pictures that you shall try to locate in the right place. To which religion and beliefs do the pictures belong to?" Shortly thereafter he added: "Your discussions are the most important part of this task.You must simply reflect." Even though the teacher encouraged the students to discuss and reflect, he gave a clear indication of what this discussion and reflection should result in. He expected the students to acquire a specific academic form of knowledge. The teaching therefore equalled a DI as to what the students should achieve (by locating the pictures in the right place). During the group interview, the teachers pointed out that the purpose was to encourage the students to reflect, argue and discuss, and thereof figure out what was right.

\section{Indirect summoning which is specified}

After the individual work, the social science teacher asked the students to share their opinions on what they associate with the concept of power. At one point the teacher responded thus: "Some of them [the opinions] are quite obvious - they are associated with power. I hope you think thus: That was smart, I had not thought of that, but now I have.'The teacher highlighted the good examples from some of the students, while indirectly encouraging the other students to learn from these examples. This assertion is substantiated by the following situation. After a response from one of the students, the teacher replied by addressing the whole class: "Now you must listen, as these remarks are important. Please, repeat what you just said." The student repeated his words: "Children of rich parents are spoiled and look down on others." The teacher responded, yet again, to the whole class: "Is this true? Is this the way we show others that we are rich, that is, by stating that this is not good enough for me?" The teacher made use of a student's claim and lifted it up both in a positive and questioning sense. Moreover, the teacher made use of the student's claim as an indirect summoning to the whole class, giving them the opportunity to reflect and take a stand on the issue. 
During the group interview, one teacher told us that his job was "to seed." He did so by using good examples so as to highlight valuable statements from the students. The findings also showed that the social science teacher, on several occasions, urged the students indirectly to reflect upon assertions and statements from the other students. He also used, on several occasions, the work efforts of individual students as intermediaries in the form of indirect criticism of the other students' work efforts. For example, he uttered this to the whole class: "Then I saw that some of you were writing eagerly." He praised some of the students' work efforts without criticising directly those who did not. Rather, the critique shone indirectly through the praise. At the same time, something else was indirectly 'working' through this form of criticism, as the teacher tried to spur some of the students to put more effort into their work. It all seemed to be an attempt to improve the students' work ethic.

\section{Indirect summoning which is unspecified}

A concrete example of ISU was found through the following statement by the social science teacher: "Are there any of you who have power?" Yet again the teacher addressed the whole class, with an apparent direct question which could be answered either yes or no. On closer inspection, however, the question was both complex and indirect. For the first time during the lesson, the teacher directed the question of power directly against each and every student. At the same time, indirectness was at work as the question created space for each of the students to reflect on their own relationship to power; whether they themselves have power and how they possibly use power, and so on. Metaphorically, the teacher directed a 'mirror' to the students, and through this 'mirror,' the students could assess themselves.

The observations showed that none of the students responded directly to the teacher's question, but there were new opportunities to do so, as the teacher followed up on his question with these words: "I believe some of you have more power than others. And I believe there are quite a few young people who experience power repeatedly." Notice that the teacher made use of the word 'believe' in both sentences. To believe indicates some kind of uncertainty and doubt, a form of assumption, but also an indirect 'test,' in which the students were given the opportunity to test out the teacher's assumption and belief. The indirect approach being used by the teacher is related to unspecificity as no specific directions were given other than a summoning to think and reflect, that is, the students could, if they chose to do so, think and reflect upon their own relationship to power. Yet again, the students did not respond to the teacher's reaching out, but that does not mean it was wasted. On the contrary, he had planted a seed so to speak and made it possible for the students to reflect on issues which concern their inner life and, ultimately, the way in which they exist morally in the world, in this case with regard to the concept of power.

In contrast to the social science lesson, the KRLE lesson had more focus on correct answers. We, therefore, found no use of ISU in the KRLE lesson. 
During the group interview, the social science teachers pointed out the importance of challenging the students to reflect on their own whether they exercise power and, not least, how they influence others through their own use of power. The teachers were concerned about raising self-awareness concerning power. At the same time, they emphasised that they did not look for ready-made answers. The important thing was that the students had to think for themselves. As one of the teachers said, "We were keen not to dismiss anything." Another teacher pointed out that the students' responses to experiences of power were never seen as wrong ("even though it was far from what I expected"). It was about challenging the students to respond, either publicly (aloud) or privately (in silence), and it was about the students' unique responses and opinions.

\section{Outlines for a fourth model of teaching: Direct-indirect teaching}

In the analysis of the data material from the social science lesson, we also found indicators for a fourth form of teaching - namely, an interactive combination of DI and ISU, which I refer to as direct-indirect teaching (DIT; see Figure 2.4). Even though the findings are too weak to form a new model of the theory of indirect pedagogy, they form an outline or a sketch in which there are possibilities to either develop or refute such a model by way of further research. The particular finding was very demanding to discover in the analyses because at first glance it seemed that the teacher only instructed the students directly and explicitly on what to do and what they should achieve. Here is an example.

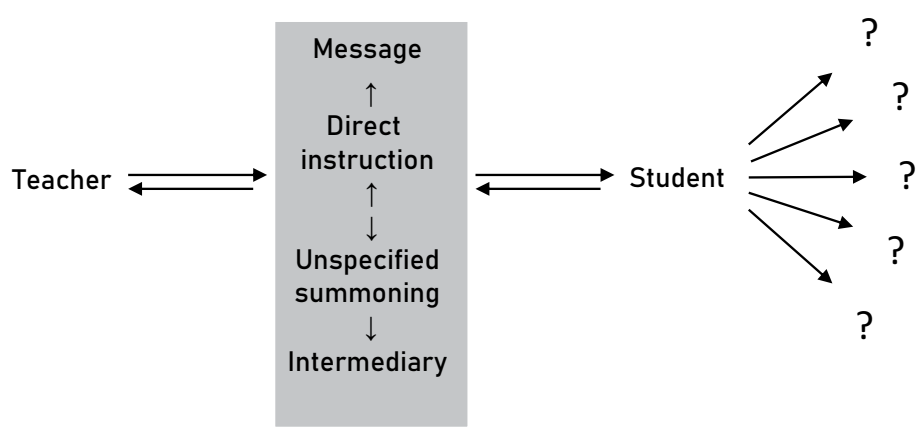

Figure 2.4 Model for DIT. The figure shows a teaching situation and a communication relationship between teacher and student. Left: The teacher conveys a message. Middle: This message is both direct and indirect. Indirectness works through directness. The message, which goes through an intermediary, does include a summon, but the summon is unspecified. That is to say that the teacher is open as to how the student should respond to the message. This is how the teacher makes room for choice. How to respond is up to the student, who may also choose not to respond. Right: The arrows and the question marks at the far right of the model illustrate that the student may respond in more than one way. The two arrows that proceed from student to teacher illustrate the student's response to the teacher. 
Now you should spend a few minutes talking together in the group, and you must make notes on the sheet I gave you. Who, among youths-you may think in general, or you can use yourselves as examples-but in any case, you should say something about who among youths have power. And you should consider or say something about how that power works, and you should write something about certain characteristics of those who possess power.

Apparently, the teacher gave DI to the students groupwise on what he wanted them to do. Although the teacher was specific and clear on what he wanted the students to work towards, he did not require a ready-made answer. He was open to what the students as a group had to say about the matter. Even though he avoided seeking fixed answers he still wanted the students to acquire some kind of knowledge through his DI.

But then, all of a sudden, he shifted strategy; that is, he no longer spoke generally of the concept of power. Rather, he contextualised the theme of power into the students' own world by asking them to consider how power works among their peers and how this form of power may be characterised.

Actually, in this case, indirectness worked through the directness. In what way? At the beginning, the teacher approached the students' own world, but not on an individual level. The teacher let there be space between the concept of power and the individual student as he urged the student group to assess the use of power by other youths. Even so, the teacher's approach can be understood in the sense that he indirectly encouraged the students to assess themselves based on the concept of power. The teacher, although this is not pronounced in pure words, minimised the distance between the relatively abstract concept of power and the individual student. Firstly, he created space for talking about, and reflecting upon, power on a general basis. Secondly, he gave room to reflect on the power of youths, and this is where the teacher indirectly created an opening for the students to reflect on their own relationship to power. It was entirely up to the individual student to do so or not. The choice was completely free.

Therefore, in my view, this is an example of ISU in combination with DI.This is supported by the fact that the teacher directly encouraged the students to perform the task in groups. While he created a certain distance between the individual student and power, he indirectly closed the distance between the individual student and power. On the one hand, the teacher let the students choose to keep this distance, thus ignoring themselves with regard to power, and on the other hand, he made room for reflection whereas the students might draw the theme of power closer to their own world.

During the group interview, the teachers stated that they would connect power "on the personal level of the students" and find out whether the students were aware that they were subjected to power and whether they themselves were using power and thereby influencing others negatively. One of the teachers asked the following question: "How much do they know about their own power?" "We wanted to investigate power among peers," another teacher stated. Furthermore, "As the goal is to make the students socially competent we have to play the ball to them." The teachers also gave the students exits as they realised that it might be easier for the students to talk about power on behalf of a group. Responding on behalf of a group does not signify whether the student belonged to this group or 
whether the student referred to a group that exercised power.Yet, there were openings for relating power to their own individual life.

\section{Discussion}

Initially, I assumed on a theoretical basis that achieving the double purpose of education - that each individual can live well in a world worth living in-will remove, and prevent the formation of, undemocratic attitudes. Instead of examining this assumption from a normative perspective, which would give us too many uncertainties to handle, we chose to locate the double purpose of education in a concrete teaching situation so that we could take a descriptive approach rather than a normative approach. The question we asked was thus, How do teachers teach to remove undemocratic attitudes and prevent the formation of undemocratic attitudes in secondary school?

There are no findings in the study as to whether the teachers succeeded in removing, or preventing the formation of, undemocratic attitudes. Such a task was way too complex for the resources at our disposal and was therefore not the purpose of the study.

Our purpose was to examine how teachers teach when it comes to removing, and preventing the formation of, undemocratic attitudes; hence, we had to find out when the teachers made use of DI, ISS, ISU and DIT. The findings revealed that the teachers of our study used these forms of teaching in different situations, after which we could categorise these uses into different fields, such as epistemology, morality and existence, and different perspectives, whether it was a third-person or a firstperson perspective (Figure 2.5). Henceforth I will discuss the following questions: When, or in what situations, did the teachers make use of direct and indirect approaches (DI, ISS, ISU, DIT) in their teaching where undemocratic attitudes were the main theme? And which fields and perspectives are these forms of teaching connected to?

\section{When did the teachers make use of direct and indirect approaches?}

The analyses of the data material show that DI was given to the students individually and in groups, as well as in connection with what they should do or perform and for results and outcomes throughout the course of the teaching. In other words, DI was used when students were about to learn something in the sense of acquiring knowledge and insight. DI was also used when the teacher explained something to the students, in particular related to the understanding of concepts. Overall, DI was primarily used for purposes of learning in an epistemological sense.

We also found that the KRLE teacher acted indirectly on certain occasions. Instead of giving the students the right answer directly, he used questions and hints to help them find the right answer. This way of teaching was therefore classified as ISS. The specificity of this indirect summoning is also related to learning in an epistemological sense, as the purpose being was acquiring certain knowledge and insight (on particular symbols used in the major world religions). 


\begin{tabular}{|l|l|l|}
\hline Models of teaching & Used in situations when: & Fields and perspectives: \\
\hline DI & $\begin{array}{l}\text { - students shall perform tasks } \\
\text { - students shall acquire knowledge } \\
\text { - students shall understand } \\
\text { concepts } \\
\text { - teachers shall explain something } \\
\text { for the students }\end{array}$ & $\begin{array}{l}\text { Epistemology } \\
\text { Third-person perspective }\end{array}$ \\
\hline ISS & $\begin{array}{l}\text { - students shall gain knowledge } \\
\text { teachers motivate for better work } \\
\text { ethics } \\
\text { - teachers urge students to take a } \\
\text { stand, whether certain } \\
\text { assumptions are true or not }\end{array}$ & $\begin{array}{l}\text { Epistemology } \\
\text { Third-person perspective }\end{array}$ \\
\hline ISU/DIT & $\begin{array}{l}\text { teachers challenge the students } \\
\text { on a subjective-existential level } \\
\text { teachers test students indirectly } \\
\text { - teachers will make the students } \\
\text { more conscious of something }\end{array}$ & $\begin{array}{l}\text { Existence } \\
\text { Morality }\end{array}$ \\
\hline
\end{tabular}

Figure 2.5 Model showing situations as to when DI, ISS and ISU/DIT were used during the observed teaching lessons and which fields and perspectives these forms of teaching are connected to. The figure is divided into three rows. Top row: The column in the middle shows four situations as to when DI was used by the teachers in our study-that is, when students shall (I) perform tasks, (2) acquire knowledge and (3) understand concepts and (4) when teachers shall explain something to the students. The column to the right shows that DI was used in the field of epistemology as a third-person perspective. Middle row: The column in the middle shows three situations as to when ISS was used by the teachers in our study-that is, (I) when students shall gain knowledge, (2) when teachers motivate for better work ethics and (3) when teachers urge students to take a stand, whether certain assumptions are true or not. The column to the right shows that DI was used in the field of epistemology as a third-person perspective. Bottom row: The column in the middle shows three situations as to when ISU and DIT were used by the teachers in our studythat is, when teachers (I) challenge the students on a subjectiveexistential level, (2) test students indirectly and (3) will make the students more conscious of something. The column to the right shows that ISU and DIT were used in the fields of existence and morality as a first-person perspective.

As for the social science teacher, he used the indirect manoeuvre in a somewhat different manner. For example, he communicated indirectly by way of praise, while criticising and motivating the students. On several occasions, the social science teacher made use of ISS, but it did not always lead up to a correct answer, contrary to the KRLE teacher's use of this model. As we have already seen, the social science teacher summoned the students to take a detour or an indirect path through the other students' claims and statements and then take a stand. Even though the teacher did not look for fixed answers in these situations, his indirectness was specific (ISS), as he relatively clearly encouraged the students to decide whether the claims and statements of the other students were true or not. 
As already stated, we found no signs of ISU being used during the KRLE lesson. In the social science lesson, however, we did find signs of teaching in which ISU was used. Through indirect summonings, the social science teacher created spaces in which students could, if they chose to do so, reflect on their own relationship to power. Several questions were not expressed explicitly by the teacher; rather, they were raised indirectly, through silence in that they were present between the lines. Examples of questions raised through silence might be, 'Do I use power?' 'How do I use power to my fellow human beings?' The students were thus challenged on a subjective-existential and moral level (Biesta, 2014; Klausen, 2018; Saeverot, 2013). The challenge became even more prominent as the teacher threw out the assumption that some of the students in the class both have power and exert power over others.

It is important to emphasise that the teacher did not go beyond assuming and believing, without any attempts at reaching a conclusion or final answer. Rather, he was both doubtful and interrogative in his approach, and because of that, he gave the students the opportunity to reflect on this and how they relate to power in their daily life. I, therefore, chose to call the teacher's approach an indirect 'test' which was unspecified as there was not a matter of finding a specific answer. No specific directions were given as to what the students should achieve, and there was certainly no use of coercion; instead, the students were given the freedom to respond in their own unique manner, and also the freedom to not respond at all.

After the social science teacher spent quite a lot of time on clarifications and understandings of the notion of power, through DI, he attempted to contextualise power by relating it to the students' world and sphere of existence. Through indirect questions and personal assumptions, he indirectly summoned the students to turn their eyes on themselves and thereby reflect on their own relationship to power.

Thus, the teacher, in my view, related to the double purpose of education; firstly by drawing attention to the students' individual world and, secondly, by how they existentially and morally relate to other people, society and the world in general. There is also support in the data material for claiming that the teacher in this way - that is, by way of ISU-worked to remove undemocratic attitudes and prevent the formation of undemocratic attitudes in light of power.

But as I said, this was not specified by the teacher, and the choice was entirely up to the students themselves. The teacher then avoided lifting a moral pointing finger, giving explicit instructions as to how the students should relate to power. Such a strategy contains both advantages and disadvantages. While the disadvantage may be that the teacher cannot know whether the students will choose to reflect on their own relation to power or not, the advantage is that the students can freely choose to do so, or not. If we imagine that the students choose to relate power to their own lives, then what? In such a case, one might imagine that the students can have an inner conversation with themselves, even judging themselves and, so to speak, point the moral finger at themselves. Directing the directives at oneself in this way is synonymous with a first-person perspective. It is not a third person who does this for them, even though this third person - the teacher-has indirectly summoned them to do so. 
Figure 2.5 summarises and categorises the main findings of the study while explaining why teachers alternate between the different forms of teaching.

While the teachers used DI and ISS in situations when it was important to achieve knowledge of terms and concepts, ISU and DIT were used when the teacher challenged and tested the students on a subjective-existential and moral level, and, inter alia, to remove, and prevent the formation of, undemocratic attitudes. Both DI and ISS are connected to epistemology and are relatively teacherdriven; that is, the teacher appears as a third person, one that the students must trust, at the cost of self-trust. ISU and DIT, on the other hand, are connected to existence and morality. The students' choices, responses and opinions, which may be completely unknown to the teacher in advance, are strongly emphasised. Thus, ISU and DIT are first-person perspectives, where trust in oneself - self-trust-is a prominent feature.

\section{Findings as basis for new hypotheses and further research?}

Even though the findings in no way can be generalised, they indicate that the teachers in the study have been quite aware that DI and ISS would not work in situations where they wanted the students to reflect on their way of being in the world. I, therefore, assume, based on what the teachers stated in the group interviews, that DI and ISS would simply be too direct and intrusive when it comes to issues of existence and morality. Conversely, the findings imply that DI and ISS are more suitable when it comes to epistemological matters. ${ }^{1}$

If we look at the findings in a holistic perspective, they suggest a combination and alternation between DI, ISS and ISU, and there are two main reasons for doing so. Firstly, students need knowledge and insight of concepts which are related to undemocratic attitudes, e.g. the concept of power. In such cases, DI and ISS may be appropriate ways to teach. Secondly, the findings imply that removing undemocratic attitudes or preventing the formation of undemocratic attitudes are not just a matter of achieving knowledge. Epistemology should therefore be combined to both existence and morality. An important factor the findings imply is that neither existential nor moral issues can be forced upon the students. For that reason, teachers should teach in such a manner that the students can, by way of free choices, have inner conversations with themselves on, for example, their relationship to power and how their exertion of power may affect their own and others' lives. In such cases, ISU and DIT may be appropriate ways to teach.

However, education should, in my view, investigate the appropriateness or suitability of DI, ISS, ISU and DIT more thoroughly and systematically. These forms of teachings are more or less unexplored in education. Even though the study presented in this chapter gives no answer as to whether the teachers were able to remove, or prevent the formation of, undemocratic attitudes, I believe it can have value and actuality by generating new hypotheses which can be explored in more detail by way of further research. 


\section{Note}

1 Even though we did not have an eye on unforeseeable situations, one may assume that direct instructions and expectations find their limits in unforeseeable situations (Bollnow, 1956; Saeverot and Torgersen, 2021). In cases that are unforeseeable, it is in all probability essential to make room for the language's richness of indirect words, expressions and phrases (Saeverot and Torgersen, 2021).

\section{References}

Baldacchino, J. (2019). Art as unlearning: Towards a mannerist pedagogy. New York \& London: Routledge.

Benner, D. (1995). Studien zur Theorie der Erziehung und Bildung, Band 2 [Studies of theories of pedagogy and Bildung, volume 2]. Weinhem: Juventa.

Benner, D. (2012). Allgemeine Pädagogik. Eine systematisch-problemgeschichtliche Einführung in die Grundstruktur pädagogischen Denkens und Handelns [General pedagogy. A systematik-problem oriented introduction in the foundational structures of pedagogical thinking and action]. Weinheim: Juventa.

Biesta, G. (2014). The beautiful risk of education. Boulder \& London: Paradigm Publishers.

Bollnow, O.F. (1956). Das Wesen der Stimmungen [The nature of moods]. Frankfurt:Vittorio Klostermann.

CNCDH, Commision Nationale Consultative Des Droits De L'Homme, République Française (2018). Report on the fight against racism, anti-semitism and xenophobia. Available at: https://www.cncdh.fr/sites/default/files/english_essentiels_rapport_racisme_2018.pdf (accessed 9 April 2021)

Creswell, J.W. (2013). Qualitative inquiry and research design. London: Sage.

Creswell, J. W. (2014). Research design: Qualitative, quantitative and mixed methods approaches. Washington, DC: Sage.

Dewey, J. (1966). Democracy and education. New York: Free Press.

Dewey, J. (1998). Time and individuality. In L. A. Hickman, \& T. M. Alexander (Eds.), The essential Dewey, volume 1. Pragmatism, education, democracy (pp. 217-227). Bloomington/ Indianapolis: Indiana University Press.

Hattie, J. (2009). Visible learning: A synthesis of over 800 meta-analyses relating to achievement. New York \& London: Routledge.

Heitger, M. (2004). Bildung als Selbstbestimmung [Bildung as self-determination]. Paderborn: Schönigh.

HL-Center (2012) Antisemittisme i Norge? Den norske befolkningens holdninger til jøder og andre minoriteter [Antisemitism in Norway? The Norwegian population's attitudes towards Jews and other minorities]. Available at: www.hlsenteret.no/aktuelt/publikasjoner/hl_rapport_2012_web.pdf (accessed 20 August 2020).

Hoffmann, C., \& Moe,V. (2017) Holdninger til jøder og muslimer i Norge [Attitudes to jews and muslims in Norway]. Available at: www.hlsenteret.no/aktuelt/nyheter/2017/hl-rapport_29maiweb-\%282\%29.pdf (accessed 20 August 2020).

Irigaray, L. (2001). Democracy begins between two (K. Anderson, Trans.). New York \& London: Routledge.

King, K., \& Hornberger, N. H. (Eds) (2010). Research methods in language and education. Berlin: Springer.

Klafki, W. (2001). Dannelsesteori og didaktik - Nye Studier [Theory of Bildung and didactics - new studies]. Århus: Klim. 


\section{Teaching}

Klausen, S. H. (2018). Søren Kierkegaard. Educating for authenticity. Berlin: Springer. https:// doi.org/10.1007/978-3-319-73186-5_1

Kvale, S., \& Brinkmann, S. (2009). Det kvalitative forskningsintervju [The qualitative interview of research]. Oslo: Gyldendal Akademisk.

Mason, J. (2002). Qualitative researching. London: Sage.

Meyer, M. A., Meyer, H., \& Ren, P. (2018). The German Didaktik tradition revisited. In J. Chi-Kin Lee, \& K. J. Kennedy (Eds.), Theorizing teaching and learning in Asia and Europe (pp. 179-216). New York \& London: Routledge.

Nielsen, K., \& Klitmøller, J. (2017). Blinde pletter i den synlige læring. Kritiske kommentarer til "Hattierevolutionen" [Blind spots in visual learning. Critical remarks to the "Hattie revolution»]. Nordic Studies in Education, 37(1), 3-18.

Peters, R. S. (2007). Education as initiation. In R. R. Curren (Ed.), Philosophy of education: An anthology (pp. 192-205). New Jersey: Blackwell.

Reichenbach, R. (2011). Pädagogische Autorität. Macht und Vertrauen in der Erziehung [Pedagogical authority. Power and trust in education]. Stuttgart:Verlag W. Kohlhammer.

Rucker,T. (2020). Teaching and the claim of Bildung:The view from general didactics. Studies in Philosophy and Education, 39, 51-69. https://doi.org/10.1007/s11217-019-09673-0

Saeverot, H. (2011) Praising otherwise. Journal of Philosophy of Education, 45(3), 455-473.

Saeverot, H. (2017). Pedagogikkvitenskap [Pedagogical science]. Bergen: Fagbokforlaget.

Saeverot, H., \& Biesta, G. (2013). On the need to ask educational questions about education. Policy Futures in Education, 11(2), 175-184.

Saeverot, J. (2013). Indirect pedagogy. Some lessons in existential education. Berlin: Springer.

Saeverot, H. \& Torgersen, G.-E. (2021). Ideologies, threats and sustainability. How can education and knowledge of the unforeseen help reduce the threat posed by ideologies? In $\mathrm{H}$. Saeverot (Ed.), Meeting the challenges of existential threats through educational innovation: $A$ proposal for an expanded curriculum (pp. 145-162). New York \& London: Routledge.

Stojanov, K. (2018). Education, self-consciousness and social action. Bildung as a neo-Hegelian concept. New York \& London: Routledge.

Terhart, E. (2011). Has John Hattie really found the holy grail of research on teaching? An extended review of Visible Learning. Journal of Curriculum Studies, 43(3), 425-438.

Uljens, M., \& Ylimaki, R. M. (2017). Non-affirmative theory of education as a foundation for curriculum studies, Didaktik and educational leadership. In M. Uljens, \& R. M. Ylimaki (Eds.), Bridging educational leadership, curriculum theory and Didaktik. Non-affirmative theory of education (pp. 3-145). Wiesbaden: Springer.

Wengraf, T. (2001). Qualitative research interviewing. London: Sage. 


\section{Communication}

\section{Janus-faced forms of indirect communication. Teacher interview and thought experiments}

The main theme of this chapter is communication. There are countless communication theories, for example, connected to information technology, relations, language, media and organisation. Within these main areas there are innumerable subgroups of communication theories. Instead of going into more detail on these communication theories, I will in this chapter try to lay some foundations for the development of a pedagogical communication theory, based on three forms of indirect communication-namely, irony, deceit and existential communication through pictures. These forms of communication are often omitted in education, in particular irony and deceit, because they may be detrimental to students. I argue that this is very unfortunate because these indirect forms of communication also have a potential to educate.

Merriam-Webster defines communication as "a process by which information is exchanged between individuals through a common system of symbols, signs, or behavior." Nearly all education happens through communication. If education is to happen, teacher and students must communicate. Good communication is usually correlated with good education (Heslep, 2001). If the communication is not working properly, it will affect the relationship between the teacher and the students. Poor communication can also create distrust between the two parties (Platz, 2021). There are many different ways to communicate: verbally, non-verbally, in writing or visually. Under each of these main groups, there are numerous forms of communication, e.g. dialogue, questioning, explaining, persuasion, negotiating, etc. The list of forms of communication is endlessly long and naturally, there is a need to select and deselect different communication forms. In this chapter, I will look more closely at three forms of communication which are connected to indirectness in education - that is, irony, deceit and visual communication.

Some may claim that such forms of communication, at least irony and deceit, are detrimental in that the recipient, in this case the student, may be exploited, manipulated and tricked, possibly leading to distrust between the teacher and the student.This is to a certain degree true. The simplest and most common solution to this problemthat certain communication forms may be detrimental-is to exclude such forms of communication from educational situations. We should nonetheless not take a 
unilaterally negative view to these forms of communication, as they are Janus-faced. By that I mean that some forms of communication may be detrimental on one hand, but on the other, they may be fruitful in certain educational situations.

However, since we are speaking of rather extreme remedies such as irony and deceit, which may be some of the most extreme forms of communication, they must be used with caution. Importantly, those who make use of Janus-faced forms of indirect communication in an educational situation must have adequate insight and competency of these communication forms, both the positive and negative effects they may cause. If this is not the case, such indirect forms of communication should not be used at all.

In the following, I will attempt to answer the question of how irony, deceit and existential communication through pictures can be used indirectly and responsibly within educational practice. Since we are speaking of Janus-faced forms of communication, they will be evaluated from two different educational angles - that is, both detrimental and educative perspectives. In order to stay as close as possible to the field of educational practice, I will use excerpts from interviews with a teacher working in upper secondary school, as well as examples and thought experiments connected to teaching.

\section{Irony}

The topic and context of the following section is the use of irony in upper secondary education. My point of departure is an interview with "Emma," a well-versed arts and crafts teacher, after which I comment and discuss whether her uses of irony are detrimental or somehow beneficial for educational purposes. My 'analysis tool' is a Kierkegaardian understanding of Socratic irony which I explain next. The section is split up in two parts, where I discuss and analyse two cases from upper secondary education. Common to the two cases is that the teacher makes use of irony in a Socratic and self-deprecating manner. Before this, however, we should look into the concept of irony.

\section{The concept of irony}

There are many different forms of irony within the context of education (cf. Lear, 2011; Nehemas, 1998; Smeyers, 2005; Smith, 2020; van Goor \& Heyting, 2006; Vasiliou, 2002; Vlastos, 1991). The most common form of irony is to express something other than, and especially the opposite of, the literal meaning. The problem with this form of irony is that the recipient is faced with the task of interpreting the message, where the answer will either be right or wrong. It is easy to misunderstand. The same form of irony can also be abused, as the persons who make use of irony intend to show their intellectual strength to the other party, who in turn is portrayed as stupid and oppressed. That is why this form of irony is not very suitable in educational contexts. Nor is it surprising that irony has gained a bad reputation, but unfortunately irony and similar forms of communication have been more or less omitted in both teacher education and courses and programmes in education. The attitude is that irony and indirectness should be kept away from all forms 
of practical education because they can be harmful to the students. One is blind to the other face of irony or that irony also can have educative effects.

So how do I understand irony? Originally, irony is about feigning ignorance. This deceitful behaviour is directly linked to the Greek word for irony, eironeia, which means to conceal something, pretending not to know (Campos-Daroca, 2019 , p. 251-252). This traces back to the classic Greek theatre character Eirôn who understated his own abilities (ibid., p. 252), a method also used by Socrates in his conversations (Smith, 2011, 2016). Of course, the ironist can hide something and then reveal something else. Kierkegaard avoids such a form of irony. He relates to both Socrates and the original meaning of irony. That is, Kierkegaard as an ironist wears a mask, just like Socrates and Eirôn, but behind the mask of the Danish thinker, we find no face (Kierkegaard, 1992a). That may be possible by, for example, combining jest and seriousness in one and the same sentence (Kierkegaard, 1991, p. 133). Such a sentence can be taken as serious or a joke. None of these understandings are either right or wrong. Not even the ironist can say that 'the message' is either serious or just a joke. In fact, there is no message. Thus the ironist appears as "a nobody [...] an absentee, an objective something, a nonperson," whereupon the sentence appears as "a dialectical knot" which the recipient must solve (ibid.). Another example, perhaps more suited to education, could be to bring praise and criticism together so that no one can say directly whether the ironist is praising or criticising. What is the message here? Praise or criticism? The answer is that it is entirely up to the recipient to decide; he or she must solve the dialectical knot. I refer to this form of irony as ironic indirection. Let us now turn to the first case on which I shall comment and analyse.

\section{The case of two foreign boys}

During the interview with Emma, it was revealed that the school had recently received a new machine that Emma was to use in teaching. Both Emma and the students had to learn how to use the machine. I was also told that there were two immigrant boys in the class, one of whom spoke Spanish. Emma informed me that the boys often struggled to concentrate during class, and she thought these difficulties likely stemmed from them struggling with the language. When Emma looked at the manual for the machine, she noticed that it was also written in Spanish. This was an excellent opportunity for her to get the boys involved. She described the situation as follows.

EMMA: Then I said: "I need help here, boys, I can't figure out the technical stuff. The manual is even in Spanish." They came running. They were so eager, they almost lost it. I pretended to be as stupid as can be. We read the manual in Spanish and tried to translate it into Norwegian. Suddenly this South American boy was the champion of this machine and felt brilliant. I'm quite manipulative at times. I did understand how to use the machine, because the manual was written in Norwegian, too, but it was a way of catching the attention of these two boys who just sat there wasting time while being unfocused. I had 
to seize the opportunity. I could have taken the lead and told them what to do, but instead, I let them figure it out themselves, and when they started their work and had to use the machine, they knew exactly what to do and showed great satisfaction in having understood it "without any help." The students were so helpful, cheerful and obliging. It's those funny little situations that are so important to utilize. That's the sort of thing you can't plan for. I often find that if you give the students your trust, and you're not afraid to show that there's something you as a teacher don't understand, the students will happily help you. The teacher does not have to be perfect or know everything, because the students can learn something along with you, or figure something out for you. That's perfectly fine, I've done it from the beginning of my career as a teacher. And if there's anything I don't understand, I always ask the students first before I go and get help. I'm secure enough in myself to do that. It's a part of the way I organize things to have the students help each other if someone is good at something. And sometimes they are better at it than me.

Emma utilises a moment here, a "funny little situation," as she puts it, and becomes an actor of sorts. She takes on the role of an ignorant person in need of help. In other words, Emma takes on an ironic stance, where she pretends to lack knowledge, much like Eirôn and Socrates who understated their own abilities. This is a form of deceit. At the same time, she catches the two boys' attention without any planning because such "funny little situations" cannot be planned. By feigning ignorance, she makes herself look less knowledgeable than the two boys. She does not need to portray herself as the teacher who always knows more than the students. Thus she sacrifices her own ego for the sake of her students and with an educational intention of giving the boys the opportunity to solve the problem.

In this way, she gives the boys indirect recognition. This recognition is not expressed explicitly or directly, but through two intermediaries: firstly, through her own feigned ignorance ("I can't figure out the technical stuff") and, secondly, through her unspoken trust in the boys to solve a problem that she ostensibly cannot solve herself ("I need help here, boys"). Emma thus provides space to uplift the boys, in that they will experience a sense of accomplishment. Furthermore, the students' practical insights and knowledge, as pertains to linguistic and technical skills, is given value in a school that can often be too concerned with theoretical skills.

The problem with Emma's use of irony is that she has emerged as a person who knows where she is going. Instead of creating a contradiction without a right or wrong answer, she hides something specific - namely, the fact that she does know how to use the machine. Hence there is a face behind her mask. She may therefore be recognisable instead of an unrecognisable nobody, an absentee, a nonperson. Her irony appears as ironic direction due to the specific deceit, and she is in danger of being exposed. Thus, Emma's actions, which are both direct and indirect, find themselves in an ethically grey area. She takes the "spotlight" off herself and directs it to the two boys. At the same time, she puts her trust in them by concealing the fact that she knows more than she is letting on. This is an act of indirectness, where she creates a situation that greatly benefits her students. But their mutual trust hangs by a 
thin thread that can easily break if the two students, or any other students for that matter, discover the specific deceit and see through her 'game.' For this reason, it is important to consider carefully whether to use this form of irony in educational practice. On one hand, the use of ironic direction allows Emma to indirectly help the boys accomplish a task so that they can feel useful. This may be of great value to the boys. On the other hand, she risks creating distrust if her act is revealed for what it is. For this reason, teachers must ask themselves: Is this worth the risk?

If Emma had managed to create a contradiction by connecting $\mathrm{X}$ and $\mathrm{Y}$ without either of the two factors being either right or wrong, she would have risked much less. She would have opened up for a double reflection for the students (Kierkegaard, 1991, p. 133), meaning that they had to reflect upon two factors, both X and Y. As long as no one can say directly whether X or Y is true or false, Emma would not be in danger of losing trust because she had not hidden anything that could be revealed once and for all. Emma could therefore have appeared as a nobody without having a definite opinion on how to solve the educational task or the dialectical knot. Let us move on to the next case.

\section{The case of Elisabeth}

Emma says that she often holds back words and actions. For instance, she keeps to herself the fact that her students' ideas were her own. This is another way of using irony's self-deprecating manner and an indirect way of giving the students ownership over their ideas, notions and thoughts. She tries to avoid a third-person perspective where the students depend on her, and at the same time tries to create a first-person perspective where the students' points of view are prioritised.

EMMA: I'm quite manipulative as a teacher. Sometimes, I'll give the students a hint, and it doesn't quite sink in. Then when the time comes for the students, they will bring up the same ideas: "I have an idea!" It may be the same thing that I've been trying to make them understand, but the important thing is that now the students are ready, have thought for themselves, and it feels right to them.

Emma shows confidence as a teacher, by letting the students feel that they have come up with ideas and thoughts. She has no need to have the last word or to say "I told you!" Her goal is for the students to say: It was me (first person), not the teacher (third person) who had this idea.

In this context, Emma refers to "Elisabeth." Elisabeth is described as follows. She is often loud and disruptive in class, generally does poor work and can at times be rather inconsiderate towards her classmates.

EMMA: Elisabeth keeps trying to make me angry, provoke an argument, so she won't have to do anything.

Emma's goal was to try to overcome this attitude in Elisabeth. First of all, she tried to catch Elisabeth's attention and lead her to think for herself so that she could choose 
to change her behaviour, becoming more considerate and solicitous. Emma said that Elisabeth had recently had an idea for an assignment: "Can we redesign and decorate some furniture?" Emma thought this was a good opportunity to get Elisabeth involved, and it was a useful assignment that could be both practical and educative. For these reasons, she decided to let Elisabeth participate in creating the assignment.

EMMA: She doesn't have the concentration for it, but I'd like to try. It would be interesting to see Elisabeth meet herself here, considering that she usually won't do any work in class. She has brought up a suggestion, and I want to let her develop an assignment. I use moments like these, too, if you see what I mean, to teach Elisabeth a life lesson by giving her a reverse responsibility. She will experience sitting on the other side of the desk. I like seeing sensitivity and empathy in Elisabeth. She actually lacks empathy and is rather inconsiderate to the others. If I can pull this off, the task is worth it. Of course, it's quite manipulative, but Elisabeth does not need to know that. She only needs to feel that she has had a say in this. And then we'll see if she is able to implement the assignment that she herself has helped create.

Elisabeth is not only to perform a task, but she is also set to create the task to be conducted. She is to sit on the other side of the desk, like a teacher, and is thus given a reverse responsibility. The goal being that she may meet herself or see herself from a teacher's point of view - so as to develop sensitivity to the other students. This is Emma's educational goal, but what about her method and its ethical consequences?

The method is indirect. While Elisabeth may think she has made all the decisions, Emma is the intermediary, as she has actually stood behind it all, being in control. It is Elisabeth who has taken the initiative, but from there it is Emma who directs both thoughts, actions and emotions in a certain direction. Elisabeth is only meant to feel that she has had a say, as Emma puts it. From Emma's educational perspective, it is all about getting Elisabeth more involved, both socially and academically, as well as building her self-confidence. This is why Emma wants Elisabeth to feel that she has participated in deciding and creating an assignment. In this way, Elisabeth is indirectly recognised by Emma as a responsible and independent person.

However, we do not know if Emma's plan worked or not. If we imagine that the plan worked, that Elisabeth developed more sensitivity and empathy, then what? In that case, all parties would, so to speak, have won, both Emma and the other students and not least Elisabeth herself.

But where to draw the ethical line? Is it ethically legitimate to let Elisabeth feel that she has had a voice in the decisions when she actually has not? And what would happen if Elisabeth, or the other students, saw through this? Is there a risk of creating distrust? Yes, indeed. For example, if Elisabeth would have noticed that Emma's faith in her was not real, that would probably be crushing to Elisabeth.

On the whole, Emma conducts a too simple form of irony. Emma has good intentions, but she is far too controlling, standing behind and pulling in secret the strings of her student. Due to her strong appearance and control, she is not able to make herself a zero or a nobody. The dialectic between $\mathrm{X}$ and $\mathrm{Y}$ is therefore absent. 


\section{Deceit}

But a deception, that is indeed something rather ugly. To that I would answer: Do not be deceived by the word deception. One can deceive a person out of what is true, and - to recall old Socrates - one can deceive a person into what is true. Yes, in only this way can a deluded person actually be brought into what is true-by deceiving him.

(Kierkegaard, 1998, p. 53)

To most people, deceit is solely a negative thing; however, Kierkegaard shows, referring to Socrates, that it is possible to deceive people into both untruths and truths. Deceit is two-faced in the sense that it can have negative and positive effects. It is a negative deceit when the intention is to exploit and suppress. On the other hand, it is a positive deceit when it metaphorically helps open someone's eyes who is blind to cheating, dishonesty and other forms of deceit. As such, and as I will explain further, deceit as a pedagogical awakening can help develop a sensitivity to, and an intuitive ability to uncover, different forms of deceit and dishonesty. In this way, the deceit can contribute to the development of a kind of intuitive knowledge where the recipient can detect and sense that something is not as it should be, that it may be deceiving.

This is an important skill in today's society, particularly in the online world, where the Internet and digital media are rampant with different kinds of deceits, such as grooming, image doctoring and fake news (Szkudlarek, 2021). In a digitalised society, it is important to know how to recognise such deceits to help oneself, and others, to avoid becoming suppressed by the deceivers. Here is where deceit can be used as a pedagogical means for that which is good. That is to say that deceit can be used in a teaching setting to expose other forms of deceit, and in that way develop intuition and sensitivity so as to be able to reveal that words or pictures, or whatever, are deceiving.

In the following, I will argue for two fundamental ways of using deceit as an educative and indirect means - the educative deceit (Saeverot, 2010). On the one hand, one can be directly educated by the deceit itself. On the other hand, one can be indirectly educated by the deceit, by way of a teacher. However, and as I stated previously, one should not use deceit in teaching without being aware of its detrimental sides. For this reason, I will start by looking more closely at the destructive potential of deceit.

\section{Seduction is young and beautiful, deceit is old and ugly}

As Kierkegaard implied in the quote above, deceit is usually seen as something immoral or evil, and rightly so when people go behind each other's backs and deceive at the expense of others. Things are not always what they seem, which is a classic example of how deceivers often proceed (Faulkner, 2013; Saeverot, 2010). Deceivers typically misguide others to think in a particular way, while they do 
something else in secret. The deceit is successful each time the other party fails to notice what is actually happening and in this way falls for the act, even if it is all happening right in front of the person's eyes. That is why deceit often works through seduction. One can find examples of this in the world of art, such as in Simon Vouet's painting The Fortune Teller from 1617.

This painting, which is a variation of Caravaggio's painting The Fortune Teller (1594, Musei Capitolini, Rome), shows a young woman reading a young man's palm. At first sight, it looks like she is telling his future; however, this is only deceit. The young woman seduces him, too, by looking into his eyes. The deceit happens along with the seduction. ${ }^{1}$ Through the seduction and the erotic energy this woman creates, the man's interest towards her attractiveness is awakened. As for deceit, the young woman deceives the young man by giving him the impression that she will predict information about his future life. The two of them are seemingly playing the same game, that she will tell his fortune. However, she changes the game without the young man knowing it. Her deeply hidden intention is to steal his ring. This is the deceit.

As we can see in the painting, she holds his left hand in her right while touching his palm with her index finger. The young man clearly trusts 'the fortune teller.' He is seduced, led astray and does not notice that the old woman tries to steal something from him. This is where we find what may be the greatest difference between seduction and deceit. As a seductress, the young woman meets the man face-to-face, building trust between them. As a deceiver, on the other hand, the older woman goes behind the man's back. She can go there unnoticed if the seduction has been successful. This is because, as Vouet depicts it, seduction is young and beautiful, whereas deceit is old and ugly.

We find a similar example of seduction and deceit working together by having a look at how Joseph Goebbels (1897-1945) thought and acted when he was a minister of propaganda for the Nazi Party in Germany. Goebbels's endeavours did not just include terror, threats and violence but also brainwashing, mind control and mass suggestion. Guido Knopp's documentary film Hitler's Generals [Hitler's Helfer], 1996-1998) contains footage of an interview with Goebbels. In it he says,

This is the secret to propaganda [...] the saturation of a group of people with propagandist ideas without their even noticing it. Of course propaganda has a goal but the goal must be so clever and so brilliantly concealed that the people who are to be influenced by it don't notice anything.

The quote reveals that National Socialism had its specific goal, but the means taken to get there needed to be hidden so that the message could sneak into people's minds, unnoticed, and thus become part of the seduced and deceived person's way of thinking and acting.

In the same documentary, we meet a journalist who during World War II saw himself as opposed to National Socialism, but as he looked back on things he had written, he realised that his writings had actually been dangerously close to the ideas of National Socialism. Thus he implies that he had been seduced and deceived by the National Socialist propaganda without being aware of it. He had encountered powers that he could not resist because these powers had seduced him and 
had weakened his senses so that the concealed and deceptive message could pass unnoticed into him, so to speak behind his back, and become part of his thinking, later to be found in his writing.

What is detrimental with both seduction and deception is that they can take control over the recipient. Someone who is seduced and deceived is controlled by another person's will. The free will of the receiver is oppressed. Persons who are seduced and deceived become illusions of themselves; that is, they believe that they think and act according to themselves, but in reality, they end up as servants of a particular doctrine, ideology or similar - something that will give the manipulator various kinds of advantages. As for Goebbels, he wanted a large number of people to surrender to the National Socialist Party, as that would increase the power of the party and himself. The manipulator gains something because the recipient's will is no longer free but managed and controlled by someone else, without the person even being aware of it. In doing so, the seduction and deception serve an egocentric purpose, in which the recipient is treated as an object, rather than as a subject.

\section{Two forms of educative deceit}

Other examples of deceit are found in war, terrorism and other forms of suppression and violence that rarely show their true colours until the act itself is done. Before such acts show their true colours - that is, before the absolutely destructive and suppressive act-we are dealing with something unanticipated because it is wrapped up in deceit. The recipient does not see it for what it is because what leads up to terror and suppression often appears to be something else. Another example is retouched images depicting persons as "perfect." It could be, for instance, an image of a slim and attractive girl with no visible flaws. Documentary images in the media can serve as yet another example, where important events have been edited out. In both the latter examples, the image deceives, and those who do not grasp that fact can easily be tricked into believing that what is depicted in the image is real. A third example is so-called grooming, meaning that an adult establishes contact with a child, intending to meet the child in person to commit some form of sexual violation. The contact is often made online, preferably in closed fora such as chat groups, Facebook, Skype and online games. The goal is often to get to know the child and then create trust. When there is an intent of sexual exploitation, this is a severe form of deceit.

However, we must also be aware that deceit is often ambiguous and can bring about paradoxical effects, and not least educative effects. This can occur in two ways. First, education occurs directly through the deceit. This is a completely indirect form of teaching, in that no direct instructions are given. As such, this is an especially demanding form of educative deceit. The education consists in deceiving, in hopes that the recipients will discover this themselves - that is, through the act of deceit itself, which functions as an indirect-educative means. Through the deceit, the recipients are indirectly summoned to struggle with falseness and uncertainty. 


\section{Education \\ Deceit ----------- $\rightarrow$ Recipient}

Figure 3.I Education through the deceit.

\section{To be educated directly by deceit}

As Figure 3.1 illustrates, we are dealing with education through the deceit itself, which can be conducted in different ways within teaching. For instance, a teacher might simply strive to deceive the students, and as the deceit both covers and uncovers, a space for education is created through the deceit. In other words, the inherent and hyper-dialectical ${ }^{2}$ forces of the deceit make it possible to reveal it to be deceit. Thus, students can reveal the deceit through the deceit itself. There are also other ways to use this form of educative deceit in teaching contexts. How this could be done depends upon the situation and who the involved students are. For instance, the teacher, like Eirôn (see the previous discussion), may consciously make use of understatements or weaker expressions than expected. The teacher thus deceives by taking a diagonal step, so to speak. In this way, the students can either be deceived or discover the deceit and simultaneously disclose the "truth."

A more advanced and challenging form of educative deceit is for the teacher to let the students, so to speak, sink deeper and deeper into a deceiving world. The deceits produced by the teacher give the students a diminished and distorted point of view, and there is always a trap awaiting the students. A specific example of this is a teacher who challenges the students' vision through trompe l'oeil paintings, where the painter fools the viewer's eye by painting a realistic image, only to create an optical illusion. The teacher can even increase the challenge by stating that something is false, when in reality it is not. By deceiving in this way, the teacher turns everything on its head and creates a sort of reverse trompe l'oeil painting. As far as positive results of this deceitful strategy go, we can metaphorically imagine the students' cups being filled to the brim with deceit, until they are about to run over, and the students awaken.

\section{To be educated indirectly by deceit}

As stated, there is another form of educative deceit, which is particularly helpful for those who are not educated directly through the deceit. The recipients are given a helping hand, through indirect pointers, hints and winks, making it possible to realise what they did not see at first glance. Although this form of educative deceit is less demanding than the first one, it is still a challenge to uncover the deceit because the students have nothing direct to latch onto-but, obviously, the difficulty depends on how direct and clear or indirect and unclear the teacher's hints and winks are.

As Figure 3.2 illustrates the students are not being educated directly through the deceit, but through opposing forces in the form of indirect pointers. These counterforces function as indirectly educational means to reveal the deceit. The teacher thus appears as an intermediary between deceit and "truth," where the students are provided with hints and winks that can guide them out of delusion. 


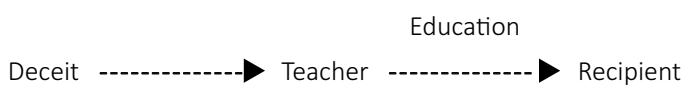

Figure 3.2 Teacher as intermediary between deceit and "truth".

The following should be added. If a teacher's hints become too direct and obvious, we may easily end up in a third-person perspective where the students become totally dependent on the teacher to expose the deceit. The teacher must evaluate whether this is necessary. It may be necessary to use relatively clear hints with some students in a beginning phase. But in order to ensure a first-person perspective, where the students feel they can reveal the deceit themselves, and that they can discover what has previously been ungraspable, the teacher should avoid using direct or explicit hints and winks. How direct or indirect the teacher ought to be depends on the situation and the students. This requires a certain discernment from the teacher.

\section{Existential communication through pictures}

How may one teach by way of existential communication through pictures? The question raises other questions that need to be answered first. What signifies existence? Is it valid to bring the topic of existence into teaching? Is it about creating a meaning of life? As soon as these fundamental questions have been answered, I will dive into a thought experiment from one of Søren Kierkegaard's (1813-1855) fictional characters, Anti-Climacus, where a teacher teaches by way of a Christianexistential communication through pictures. The objective of this teaching is to move the student to Christianity freely, through his own will (Kierkegaard, 1991, p. 171). Thereafter I will perform a Kierkegaardian repetition (Kierkegaard, 1983), that is, I shall repeat Anti-Climacus' thought experiment, contextualising it within our own time. The question I am trying to address is this: Where is the line between manipulation and teaching for the freedom of choice with regard to existential communication through pictures? Since I am about to take a historical perspective, it is natural to turn to Christianity, but in the repetition, I go beyond the Christian ideology.

\section{Coming into existence}

Whenever existence is brought into education, teachers stand before a particular challenge because they are in no position to tell students how to live their lives (Biesta, 2014; Saeverot, 2011, 2013, 2015, 2019). Existence is a subjective matter and not an objective matter with predetermined standards and goals. This can be explained historically by looking back to the rise of Pietism in the late 17th century in Germany. Today, many associate Pietism with a radical sect within Christianity, and it has rightly been accused of making use of punishments in the upbringing of children (Gehrz, 2015). However, we should not overlook that Pietism developed as a reaction to Lutheranism. According to the Pietists, with 
Philipp Jacob Spener (1635-1705) and August Hermann Francke (1663-1727) in the forefront, Lutheran Christianity had developed into a study, where Christianity was contextualised within an intellectual framework. As an antithesis to this intellectualisation of Christianity, the Pietists believed that Christianity was a matter of existence and that it had to be brought into existence rather than just thinking about it (Gehrz, 2015). In this perspective, Christianity has meaning in actual everyday life.

Similar to the original ideas of Pietism, Kierkegaard felt that Christianity should not be taught in a top-down system where the individual must relate to a truth that has been decided from "above" (Diem, 1959; Walsh, 2009). His opinion was that the existential perspective should be emphasised, and for Kierkegaard, this meant that Christianity should grow from the bottom-up - that is, from the individual's subjective truth, rather than being guided by an objective or universal truth (Diem, 1959; Walsh, 2009).

However, is it legitimate to bring existence into teaching? Or should education leave it to the students to take responsibility for their own subjective existence? To be sure, existence is a shared human matter, concerning all of us, and yet each of us must find our own path in life. Life does not come with a manual; individuals must find their own existential path, in interaction with the world. Each of us must be responsible for our own lives, but the question is, do we take this responsibility? The answer is that sometimes, perhaps often or only seldom, it can be easy to simply exist without really engaging in life. Indifference can easily creep into our lives. From that perspective, there is a legitimised space for education to communicate existentially - that is, to provide opportunities in which students can take a stand concerning their own life in relation to the world, so as to come into existence, as Kierkegaard (1985, p. 76) puts it. How may we understand the term 'come into existence'?

Originally, in Latin, "existence' means to "stand forth," "come out" or "appear" (Online Etymology Dictionary, 2020). To stand forth and come out is an action. It is not enough to think or feel something (internally); one must also act (externally). For instance, to think or feel that you love someone is not the same as coming out into existence. This only happens when you show, through actions, that you love the person (Kierkegaard, 1991, pp. 178-179). In an existential view of education, knowledge should be put to use (Saeverot, Reindal, \&Wivestad, 2013). It is not enough to be very knowledgeable if one does not convert the knowledge into action. The next question to be addressed is how the individual may come into existence.

\section{Composing oneself poetically versus letting oneself be poetically composed}

Kierkegaard provides an answer, but as always, he takes a Christian perspective. For this reason, we will follow him until a certain point, without ending in a Christian context. We will start by asking: Is coming into existence about creating meaning for one's life? The answer is no (cf. Biesta, 2014). To explain this further, we can consider two different ways of existing. On one hand, it is about being active and creating meaning for oneself (similar to the idea of constructivism). On the other 
hand, it is about being passive and letting oneself be created. Kierkegaard puts it like this:

[I]t is indeed one thing to compose oneself poetically; it is something else to be composed poetically. The Christian lets himself be poetically composed.

(Kierkegaard, 1992a, p. 280)

In this quote, Kierkegaard displays a difference between different stages - that is, the ethical and the religious stages. While the ethicist "chooses himself" (Kierkegaard, 1987, p. 258) and is "his own editor" (ibid., p. 260), the religious or Christian individual leaves the editorial responsibility to God and lets him-or herself-be educated or poetically composed. The idea of letting oneself be poetically composed is about being open to a possible new story of oneself.

However, such a susceptibility may require a process of destruction or unlearning, especially for those who have undergone a process of Bildung, that is, those who are cultivated and educated (Danish: dannet; German: gebildet). Kierkegaard emphasises this by saying: "But the more culture ${ }^{3}$ and knowledge, the more difficult to become a Christian" (Kierkegaard, 1992b, p. 383). The educated or cultivated self is, to Kierkegaard, merely an appearance of the self, as it has removed itself from the spiritual self.

In order to become spirit, a process of destruction of the self is required. It is about becoming primitive, like a child, where it is possible to enter a relation with God-so that one can be open and ready to receive oneself all over again (Saeverot, 2015). The concept receive is crucial because, on the one hand, it refers to something other than the active self who invents its own identity, while, on the other hand, it means letting oneself be invented by 'the transcendental educator' - that is, God. In Kierkegaard's words, it sounds thus: "[T]he individual needs divine assistance" (Kierkegaard, 1992b, p. 258). By being susceptible to the divine, or an interruption from the outside, it is, according to Kierkegaard (ibid.), possible to appear as a new creation, and not just any kind of creation, but rather as God's creation.

Kierkegaard's divide between the two aforementioned modes of existence is a theological composition, where the relationship is between a self and God. The question is whether this basic idea can be incorporated into education. If so, how? How can a teacher teach with an idea in mind of letting one's students be poetically composed?

\section{The D-Effect}

We are given a concrete example of this in Kierkegaard's Practice in Christianity (1850). Anti-Climacus, who has signed this book, takes the reader through a thought experiment about Christian education. He introduces a teacher and selects a child because the mind of a child has not yet been botched by prejudices. This is an example of "primitiveness," in the sense that the child has no knowledge of the stories about Jesus. Thus, there is no need for a process of unlearning with the goal of freeing the mind from prejudices (Kierkegaard, 1991, p. 174). 
With this as a starting point, Anti-Climacus' fictitious teacher begins the Christian education, starting by showing different pictures that are meaningful to the child. First, he shows a picture of Napoleon, followed by stories of the French emperor. Then he shows a picture of William Tell, also followed by stories. He carries on showing different pictures when suddenly the child catches sight of a particular picture "deliberately placed among the others; it portrays one crucified" (ibid., p. 174-175). This is what I prefer to call the Disruption-effect (henceforth: the D-effect).

Anti-Climacus explains that the child will not understand the image at first. Thus, the teacher explains the basic idea of crucifixion, that it was a method of death penalty used by the Romans to punish the worst crimes at the time (ibid., p. 175). The teacher conducts a form of pedagogy by way of showing and explaining, that is, visual and verbal communication combined. Anti-Climacus then asks how this may affect the child. His answer is that the child "will probably wonder how it could occur to you to put such an ugly picture among all the other lovely pictures, the picture of a flagrant criminal among all these heroes and glorious people" (ibid.).

The teacher has now reached the most crucial stage in the pedagogical act. Children, who, according to Anti-Climacus, are naturally curious, will ask what the crucified man did to be punished. It is highly important that the child is the one who initiates this so that the Christian mode of existence is not pushed onto the child. It is also time for the teacher to tell the child "that this crucified man was the most loving person who ever lived" (ibid.). Thus the teacher "accuses himself and the whole human race!" (ibid., p. 176).

Anti-Climacus then asks, "What impression do you think you will make on the child, who naturally will ask: But why were they so mean to him, why?” (ibid.). This is, according to Anti-Climacus, the moment, meaning that it is time to tell, "very vividly," of the crucified, that he "lived for only one thing-to love and to help people, especially all those who were sick and sorrowful and suffering and unhappy" (ibid.). It is also time to tell the child that the people let an infamous robber go free while choosing to crucify love (ibid.).

The effect this had on the child, according to Anti-Climacus, is that he completely forgot about the pictures of Napoleon and the other heroes. The child went on to ponder this story and became increasingly passionate. Once the child is a youth, he will understand this tale differently, and as an older man, he will not only think differently but also live differently. He will even suffer, as Jesus did (ibid., p. 178).

It is very important to Kierkegaard's pseudonym Anti-Climacus that the Christian way of life is not forced on someone against their will. Therefore, after telling the story of the meaningless killing of Jesus, the teacher can only hope that the sight of Christ on the cross would make such a powerful impression on the child that his own will would be strong enough to want to change: "You are not being compelled against your will, but blessed are you if your will compels you in such a way that you must say: I cannot do otherwise, for this sight moves me!" (ibid., p. 171). The main purpose of this indirect teaching, using the D-effect combined with verbal explanations, is that the student's own will is to be poetically composed. 
The question remains, however, whether there are several forms of manipulation at play here, as it may seem that the teacher is indirectly guiding and controlling the child towards a Christian mode of existence.

Seemingly, the boy chooses Christianity on a free basis. The teacher does not seem to choose for him. But maybe the choice is not so free after all? Prior to the boy's choice, the teacher has shown a Christian picture displaying pain, suffering and death, along with several pictures of different heroes. The boy can thus choose from several pictures; it is not just one Christian picture. The purpose of the teacher still seems to be clear, that is, the boy should focus on the Christian picture. It turns out that he has chosen a picture that clearly stands out from the hero pictures. The boy is thus faced with the following choice: He may either choose to embrace Christianity or not. But prior to this choice, the teacher has tried to influence the boy by speaking "very vividly" of the crucified. The teacher has therefore not been a nobody after all, as I pointed out at the beginning of this chapter. Rather, he has spoken in favour of Christianity and has therefore been too direct and straightforward in his existential communication through pictures. Do we thus glimpse a form of manipulation on the part of Anti-Climacus' teacher?

\section{A Kierkegaardian repetition of Anti-Climacus' thought experiment}

How can a teacher base the teaching on the idea of letting the students be poetically composed without intending to convert them to Christianity? And how can one avoid manipulation? To address these questions, I will, as stated earlier, undertake a Kierkegaardian repetition. What I am about to do is to repeat Anti-Climacus' thought experiment within a contemporary context.

To begin with, let us imagine a teacher communicating existentially by using pictures in a class where the students are about 12 years old. The teacher opens the lesson by showing a number of selfies through a PowerPoint presentation. As in the Anti-Climacus' thought experiment, we can imagine that these are selfies of people who mean something to the students. The teacher attributes stories to each of the selfies. But then, suddenly and unexpectedly to the students, the teacher shows an image of a 12-year-old boy who clearly suffers due to cruelty conducted by adults. This sort of D-effect creates scope for surprising the students, by breaking with the familiar and the expected (which is, in this case, a nice and neat selfie). The surprise and unexpectedness make the students jump at the verge of being frightened, almost compelling them to engage.

The educational idea behind this staging is to create space for an indirect effect through the picture. Rather than using the picture directly, it indirectly addresses the students through the interruption and the surprise, which may awaken the students (cf. Bollnow, 1976; Koskela \& Siljander, 2014). This also relates to the fact that we as humans sometimes exist in a self-satisfied and egotistical mode (Biesta, 2021). It can therefore be a real challenge to awake someone to become engaged. The situation may require indirect means and shocking D-effects.

That is why the teacher aims to, in the similar manner of Anti-Climacus' teacher, consciously lead the students into, or strengthen, a kind of slumber state, where 
habit and perhaps indifference control the reception of the different selfies. This is to say that the students will expect what has happened repeatedly (the presentation of selfies) to happen again, a kind of "repetition effect." Then, all of a sudden, the interruption occurs, when they are met with something completely different and unexpected (the picture of the abused boy). The educational aim is to awaken the students and hopefully draw them out of their slumber state. This is not a matter of leading the students towards Christianity or any other religious ideology, but stillis it ethically legitimised?

According to Bollnow (1976, p. 75), it is absolutely necessary, with a certain intensity, to break down a person's 'wall of indifference,' or a self-sufficient attitude, to really touch his or her inner world. It is about an awakening on an existential level and taking responsibility for oneself and others. This existential mode of thinking stands in direct opposition to advertising that sometimes aims to bring recipients into a slumber state, where their senses are dulled, and so being ready to be indoctrinated, with no opportunity to escape the coercive intentions (Bobbitt, 2020). The teacher in the previous thought experiment also attempts to dull the students' senses, but not without the essential interruption where the students are touched by a surprising and unexpected component. The intention is to move the students through the surprising picture of the suffering boy.

What can we expect to happen after such an existential communication through pictures? Ideally, according to the purpose of the teacher, we can imagine the students being pulled out of their slumber state, devoting themselves passionately to the hellish situation of the boy in the picture. Thus, the students undertake an indirect relationship to the world since the picture is only a representation of reality. However, it may also be possible to relate to the picture on a purely rational and cognitive level, without devoting to the boy's situation (cf. Patton, 2020). That said, the strong forces that the teacher stages through indirectness will likely evoke emotions that make it nearly impossible to be indifferent while ignoring the boy's horrific situation, even though some students may do so. Even if one cannot know what emotions the image will evoke, it is natural to imagine that unselfish emotions, such as tenderness and sensitivity, will be strengthened in certain students when they see the picture.

In this sense, one can also imagine that the picture might, as Elliot Eisner (cited in Saeverot, 2017, p. 73) puts it, arouse feelings of "devotion and compassion for others' living conditions.' It is about an existential awakening where devotion and compassion become a part of the person's existence. This means that the indirect relationship to reality, through art, can lead the students to undertake a direct relationship to reality in the future. Thanks to encounters with art, they may, for example, act compassionately towards their fellow human beings.

However, we should bear in mind that these thoughts are just theoretical ideas, which cannot consider every possible complexity found in an actual teaching situation. For this reason, we must also take into account that pictures used in educational situations may produce different effects than the ones discussed in this case. Nor have I in any way attempted to offer an exemplary case. 
There are still unresolved issues, involving both directness and indirectness, in the example of the teacher who repeats Anti-Climacus' pedagogical experiment.

\section{Which pedagogical measures can teachers take to prevent students from becoming detrimental by indirect forms of communication and at the same time open up to the students the educative aspects of such forms of communication?}

So far, we have seen that irony, deception and existential communication through pictures have a Janus-face. They can be both detrimental and educational to students. When it comes to irony, we have seen that irony can oppress students who do not understand the opposite meaning of what is said directly. Emma went beyond such a kind of irony by pretending not to know what she really knew. Through this deceit, she lifted her students; that is, she lifted the students' selfconfidence and opened up for them to learn and develop as human beings. Nevertheless, we find a danger here. If the deceit is revealed by the students, it could probably create mistrust between the teacher and the students.

As for deceit, we have seen that it can create paradoxes. Although the purpose of the deceit is to deceive its recipients and treat them as objects, the deceit can educate its recipients, either directly through the deceit itself or indirectly through a teacher, whereupon the recipients can appear as subjects.

We have also seen that teachers who communicate existentially through pictures-providing opportunities for students to come into existence-can easily end up manipulating students. Although teachers will avoid telling students how to live their lives, an existential form of communication may easily lead teachers, perhaps unknowingly, into manipulating their students to live a life that the teacher has, after all, predetermined.

The question is how to use such indirect forms of communication so that they can be educational and uplifting rather than detrimental and destructive. Which pedagogical measures can teachers take to prevent students from becoming detrimental by indirect forms of communication and at the same time open up to the students the educational aspects of such forms of communication? We will now take a closer look at this by way of the three forms of communication-namely, irony, deceit and existential communication through pictures.

\section{Irony combined with humour}

During the interview, Emma specified that she does not wish to appear cross or scold, in which her message is more specified and direct. She rather tries to say things in different ways, by using means such as humour and irony as indirecteducational forms of communication and action. Furthermore, she said that she often uses irony in her teaching but that she aims to do so in a humorous manner. Rather than criticising and admonishing her students, she can be ironic and 
humorous at the same time. Research, too, shows that irony is often combined with humour (Bruntsch \& Ruch, 2017; Gibbs, Bryant, \& Colston, 2014) and that such a combination decreases the risk of irony being detrimental (McCreaddie \& Harrison, 2019). Other advantages to humour are that it can frame the teaching in an atmosphere of fun and at the same time open up for education (Morreall, 2014; Ziv, 1988). This seemed to be the case when Emma explained her use of irony in combination with humour. When students were not able to find a certain tool, even though they had been told where to find it several times, she said thus:

EMMA: Oh! Here's a tool cabinet, has this been here all along? Wow! Have you ever seen it before?

This is a form of irony where she plays a role, pretending to know less than she really does. She knows exactly where the tool cabinet is but initiates nonetheless a form of humorous language game. She also tries to involve the students in this kind of game. Even though she knows that the students have seen the tool cabinet before and that it has been there all along, she raises questions about that. We can also imagine that the irony and humour are reinforced through intermediaries, such as her facial and bodily expressions. We have no information about this, but what we do know is that Emma's sentence consists of five paragraphs. (1) Oh! (2) Here's a tool cabinet. (3) Has this been here all along? (4) Wow! (5) Have you ever seen it before?

Emma starts the sentence by saying "Oh!" With that, she pretends to be surprised by what she suddenly sees. She goes on to say, "Here's a tool cabinet," thus directing the students' attention directly to the tool cabinet. By saying $a$ tool cabinet, she chooses to speak in an indefinite form, referring to tool cabinet in general. The reason may be that she wants to avoid that her ordinance is to become too strong and that the humour and playfulness with the students can be more easily maintained. If she had chosen to say the tool cabinet in the definite form, she would have referred to a specific tool cabinet. Her ordinance could then have become too controlling, as she would have paid attention to this particular tool cabinet, and she could have risked that the irony and humour would be in danger of losing their effect.

In the third part of the sentence, she says, "Has this been here all along?" In this way, she reinforces both the humour and the seriousness that she tries to convey. Gently, she is making fun of the students for not seeing the tool cabinet. But of course, it has been there all along, and the students know that when she asks. By continuing to say, "Wow!" she expresses astonishment as if she has discovered something new, even though she has not. This is part of the humour. Finally, she asks the students, "Have you ever seen it before?”Yet again, she resorts to humour with a touch of seriousness in it. The seriousness indicates that she has an intention to educate the students. She wants them to go to the tool cabinet to find the tools they need for the assignment. Through the question, she indirectly communicates something like this: "You should have seen the tool cabinet, and you should go there to find tools." 
Obviously, Emma does not make a dialectical knot for the students to solve.Again, she makes use of a rather simple form of irony, combined with humour, in which directness goes through indirectness. It is a form of ISS that I described in Chapter 2.

But why does she choose to take a detour through the indirect? The answer may be that the indirect makes her ordinance and directive milder. The direct ordinance and control from the teacher may not feel so strong due to irony and humour, which allows the students to laugh at the situation. This is supported by research showing that humour can provoke laughter, which will create a positive atmosphere (McCreaddie \& Harrison, 2019). It is thus possible that such a positive atmosphere can convince the students to go to the tool cabinet to find the tools they need. On the other hand, Emma could have told the students directly that they find the tools in the tool cabinet. She even admitted that she had done this on several occasions, before choosing to make use of irony and humour. From the students' point of view, such a directive would perhaps feel as if they had to be obedient and do as the teacher told them to do. But, as we already know, the students did not listen to what the teacher said directly. That is probably why Emma chose a new strategy in the form of irony and humour.

Both humour and irony take a detour. These forms of communication are not direct approaches, like for instance certain forms of criticism or other similar forms of expression (Tyson, 2015). This does not, of course, mean that criticism is insignificant in teaching. The point is that certain forms of criticism, in particular direct critical judgement, can have negative consequences-though not necessarily (Hooks, 2009). For instance, a direct critique of one's work or manner may be hard to swallow for certain students, and they may need to learn to receive and handle such criticism. Humour, too, can have negative effects on students (Billig, 2005). For instance, humour may confuse younger children (Bryant \& Zillmann, 1989), and there is a risk that humour can distract and draw the student's attention away from the teacher's message (McCreaddie \& Harrison, 2019). Moreover, humour mixed with sarcasm can have a negative effect on the trust relationship between teacher and students. One reason being that sarcasm can be used to ridicule and hurt someone's feelings (Saeverot, 2013).

But where is the line between humour, irony and sarcasm? Can Emma's humorously ironic statements about the tool cabinet be taken as sarcasm? There are many factors that contribute to how humour and irony are received, such as tone, body language and context. Such factors must therefore be assessed by teachers in the heat of the moment. Regarding the benefits of humour, it may have educative effects (Chabeli, 2008; Garner, 2006; Isen, 2003; Wanzer, Frymier, \& Irwin, 2010). As we have seen, Emma's purpose was to help her students indirectly to realise where they could find the tools they needed for their work. Through the combination of irony and humour, she is teaching the students to be responsible in an indirect manner. She lets the direct communicate, so to speak, through the indirect. It is like the end of a film or a novel, where everything is arranged for the recipient to think as the filmmaker or writer has thought out in advance. Although Kierkegaard refers to such a form of communication as a "mediocre method of didacticizing" (Kierkegaard, 1991, p. 134), can it be that irony and humour 
combined can be more educationally effective in the long run than reprimands, admonishments and direct critical judgement?

\section{Educated or deceived by the deceit?}

Which pedagogical measures can teachers take to prevent students from becoming deceived by the deceit and at the same time open up to the students the educative aspect of deceit? I shall highlight five pedagogical measures: (1) deceiving in a playful manner, (2) thinking otherwise when it comes to trust, (3) incorporating the deceit as a topic in the curriculum, (4) training the students to uncover deceits and (5) preparing students, and the society as a whole, for the unforeseeable reality of crises.

Using deceit in teaching is a risky undertaking. A teacher can never be sure whether the students are being educated or led astray. In other words, there is no guarantee whether education occurs through deceit. Due to the unruly and forceful nature of deceit, it must be used with caution in teaching. In order to avoid students feeling deceived and fooled, it may be a good idea to deceive in a playful manner. As such, the teacher can invite the students into the game to avoid creating negative emotions in them. Negative emotions such as anger, bitterness, frustration and poor self-esteem can easily create distrust between a teacher and the students. For this reason, a teacher must before anything else build trust, as trust is the key to creating a healthy relationship between teacher and students. When a basic trusting relationship is established, one can think about using deceit in teaching.

That said, teachers who make use of deceit in their teaching must think otherwise when building trust with the students. Typically, trust is established by the teacher always speaking the truth. But in cases involving deceit, speaking the truth can actually be a problem. For example, irony and humour, which include deceits, will not be understood if the students interpret the teacher's words literally. To understand irony or humour with built-in deceit, the students cannot follow the teacher to the letter. Trust in this case is therefore not built on being truthful; rather, trust is built on the teachers always wanting the best for the students, even though they make use of deceit.

Using deceit in teaching is obviously a complex matter. A simple solution is not to use deceit at all in teaching, but this ignores the fact that deceit can be a powerful contribution to education because its unruliness and vitality have the power to sharpen our senses and awareness. In other words, deceit can help us discover that things are not what they seem or that we can see and hear something unexpected. In this way, deceit can help develop a form of intuition, where students are more alert and aware in the future, with an ability to see through different forms of deceit. For instance, educative deceit can help prevent what I call "network illiteracy." A network illiterate is, in short, someone who cannot read networks, with all its codes, symbols and indirect forms of communication, including deceit. To be sure, almost anyone can perceive, and to varying degrees understand, what is communicated within different network communities, but the illiteracy, also with varying degrees, can occur as soon as the forms of communication are indirect and nonexplicit. If such forms of communication are taken literally, they are doomed to be misunderstood, which is a kind of illiteracy. 
Both children and youths are susceptible to network illiteracy, as Western schools in general pay little attention to the risks of network communities in their curricula (Ruzgar, 2018; Torgersen, 2015). Because of this, we are in danger of bringing up network illiterates, who risk being suppressed due to deceit and other forms of communication. However, it is not enough to focus on this topic in the school curricula; a "good" education must also train students to uncover deceit. In this way, students can cultivate an intuition, enabling them to discover that something is deceitful, perhaps with an intent to harm and destruct. Therefore, educative efforts should be made to help students become more aware of deceits, as well as self-deceits, while simultaneously acknowledging the fact that it is impossible to free oneself completely from deceit.

In times of crises, like the current COVID-19 pandemic, a crucial step will be to prepare students, and indeed the entire population, for changes in 'reality.'The reason being that research shows that serious crises contain disorder in information and sudden changes (Saeverot, 2021; Torgersen, 2015, 2018). This is the reality of crises, which is to a large degree unforeseeable. The reality of crises stands in opposition to the 'normal' and peaceful everyday life, where most things go according to plan, where people's lives and futures can be more or less foretold. This is the normal reality, which is to a large degree foreseeable.

Despite these different realities, it turns out that many people still relate to the normal reality during crises, such as the coronavirus pandemic, simply because education systems and governments have prepared neither students nor the population for the unforeseen nature of crises. When one believes that reality should be as it was before the crisis occurred, one can easily be led into deception. A concrete example is that many during the coronavirus pandemic have blamed the constant change of rules and that the rules have become so complicated that it is not possible to live up to them (Saeverot, 2021). The frequent changes of rules have been assessed on the basis of the normal reality. However, this is partly a deceptive perception. One believes that rules and other things should be a simple and straightforward matter because one assesses them with a wrong perception of reality. The fact is that in crises new and unpredictable conditions will always arise, whereupon the rules of today must be changed tomorrow, and so on (Saeverot, 2021; Torgersen, 2015, 2018).

To be able to accept and understand the necessity of frequent changes in socially oriented advice and rules, which intervene in the individual's everyday life, there must be an understanding of the nature of the crises - namely, the unpredictable. This is one of the most important communication tasks of education systems and governments. If this education does not take place, if the unforeseen nature of the crises is not communicated clearly enough, there will be a space for deceit and consequential errors. As I suggested earlier, a typical deceit and consequential error is that people react negatively when messages and advice are often changed. This in turn can lead to mistrust in both the authorities and the well-meaning guidelines that are given. This is a danger for the societies, which we have seen several symptoms of during the coronavirus pandemic. 
The danger can further be explained by the fact that some people can choose a selfish lifestyle because they do not perceive the crisis from the point of view of the unforeseen. This also makes it more difficult, if not impossible, to be pulled out of deceit and egotistical routines. One may easily be swallowed by the deceit and the whole thing can lead to setbacks for the work against the coronavirus and other dangers as well. In the end, education systems and authorities are partly to blame for this if they fail to convey that crises contain new perceptions of reality, in which the unforeseen plays a much greater role.

\section{The teacher as nobody}

Finally, let us return to the repetition of Anti-Climacus' thought experiment within a contemporary context. Unlike Anti-Climacus' teacher who undertook a Christianexistential education, the contemporary teacher moved beyond religion altogether. He undertook an indirect approach, by way of pictures, and tried to pull the students away from their indifferent state and towards a state where they can care for others who are suffering. This is an ethics that can apply to almost all religions. Furthermore, he strived to awaken the students just for a moment. He did not strive to lead his students towards a religion or an ideology that they should either embrace or not. Are these intentions and actions ethically legitimate? Some may perhaps say yes, while others may possibly say no. I myself would question this teacher's strategy and ask whether he has been too direct and too straightforward, as he has been very clear on wanting to awaken the students from their indifferent state. We may also question whether he has manipulated the student's emotions by deliberately leading them into a state of indifference and then pulling them out of this indifference.

I also think the teacher could have been more indirect and equivocal by making himself more redundant. In addition, he could have allowed the students to act more there and then, in the situation, and not just arouse feelings, so as to let them come into existence. How might he proceed? In many ways of course; for example, he could have let the students discuss an ethical dilemma that does not have a specific answer. To begin with, the teacher could choose a theme and present this both visually and verbally. Let us imagine that the teacher chose overpopulation as a theme. From there he could have demonstrated that overpopulation creates problems for the whole world-for example, overpopulation has profound effects on the climate and global biodiversity (Stenseth, 2021). After this, he could have presented an ethical dilemma, such as free population development versus systematic measures for population reduction (Saeverot \& Torgersen, 2021). This dilemma omits a specific solution and operates like a contradiction and a dialectical knot, which allows the teacher to appear as a nobody; that is, one who cannot say directly whether one or the other solution is correct.

This does not mean that the teacher does not want anything; on the contrary, the teacher may, for example, challenge the students to find the best solutions to the ethical dilemma - that is, solutions that may be more fruitful for the climate and biodiversity compared to other solutions. The students' solutions can in turn be challenged by both the teacher and fellow students. The teacher has thus 
indicated a direction for the discussion; however, he has not influenced or manipulated the students as to how they should respond. The students are free to choose their solution to the problem. They have to untie the dialectical knot themselves.

\section{Conclusion}

Irony, deception and existential communication through pictures have in common that they are indirect forms of communication. Another common denominator is that they have a Janus-face. They can be both detrimental and educational. I have tried to show both sides and what it takes for these forms of communication to appear educational. If one is to point to a factor that is common to the three indirect forms of communication in order for them to be educational, and not detrimental, it must be the importance of the teacher appearing as a nobody or an absentee. This means that the teacher avoids appearing as a person with personal views and opinions regarding that which was communicated to the students. If the teacher communicates indirectly, for example, through irony, deception or pictures, and at the same time tries to hide something (think, for example, of Emma where she pretended she did not know what she really knows, or Anti-Climacus' teacher who favoured Christianity or the contemporary teacher who clearly wished to awaken his students from their indifferent state), the teacher appears as a didactician who wants to lead and educate the students towards something specific. The communication is direct, even if it is communicated indirectly.

To avoid such a form of direct communication and didacticising, the teacher as communicator must not be present as a person or a subject with a clear opinion about what is being communicated and taught. The teacher must at a given time step out of the communication so that the relationship between the communication and the communicator becomes completely indirect. In this way, the teacher can also avoid stepping over the threshold that leads to the unethical. For example, the teacher does not risk breach of trust, manipulation or that he takes control of the students' will. The teacher has simply given the students an educational task, a so-called dialectical knot, which they must solve in their particular manner.

\section{Notes}

1 When we look up the word seduction in dictionaries, there are often two things that come up. One is that seduction is described as something that attracts or charms (e.g. the beauty of a person) and the other is that seduction has to do with sex (e.g. persuade someone to have sex with you) (see, for example, Cambridge Dictionary and MerriamWebster). Dictionaries in general define the term negatively. However, the term can also carry a positive connotation. This is stated in a quote from one of Søren Kierkegaard's diaries. "The one who cannot seduce humans, cannot save them either (Kierkegaard, 2003, p. 148; my translation). Kierkegaard shows this time and again in his books, that is, he makes constantly use of seduction in an attempt to get his readers interested and engaged in new and different existential perspectives. Seduction can even be an important factor in teaching (see Saeverot et al. (2013) for an elaboration on seduction as an indirect form of communication in teaching).

2 I say hyper-dialectical because the forces never come to an end. 
3 Kierkegaard himself does not use the concept of culture; rather, he makes use of the Danish concept of "Dannelse," which he relates to the German concept of Bildung (Kierkegaard, 2002, p. 349).

\section{References}

Biesta, G. (2014). The beautiful risk of education. Boulder \& London: Paradigm Publishers.

Biesta, G. (2021). Holding oneself in the world: Is there a need for good egoism? In H. Saeverot (Ed.), Meeting the challenges of existential threats through educational innovation. A proposal for an expanded curriculum (115-126). New York \& London: Routledge

Billig, M. (2005). Laughter and ridicule. Towards a social critique of humour. London: Sage.

Bobbitt, R. (2020). Exploring communication ethics. A Socratic approach. New York \& London: Routledge.

Bollnow, O. F. (1976). Eksistensfilosofi og pedagogikk [Existentialism and education]. Copenhagen \& Oslo: Christian Ejlers' forlag.

Bruntsch, R., \& Ruch, W. (2017). The role of humor-related traits and broad personality dimensions in irony use. Personality and Individual Differences, 112, 139-143. https://doi. org/10.1016/j.paid.2017.03.004

Bryant, J., \& Zillmann, I. (1989). Using humor to promote learning in the classroom. In P. E. McGhee (Ed.), Humor and children's development: A guide to practical applications (pp. 49-78). New York: Haworth Press.

Campos-Daroca, F.J. (2019). Epicurus and the Epicureans on Socrates and the Socratics. In C. Moore (Ed.), Brill's companion to the reception of Socrates (pp. 237-265). Leiden \& Boston: Brill.

Chabeli, M. (2008). Humor: A pedagogical tool to promote learning. Curationis, 31(3), 51-59.

Diem, H. (1959). Kierkegaard's dialectic of existence. Westport, Connecticut: Greenwood Press, Publishers.

Faulkner, P. (2013). Lying and deceit. In H. Lafollette (Ed.), International encyclopedia of ethics (pp. 3101-3109). Hoboken, NJ:Wiley-Blackwell.

Garner, R. (2006). Humor in pedagogy: How ha-ha can lead to aha! College Teaching, 54(1), 177-180.

Gehrz, C. (Ed.) (2015). The Pietist vision of Christian higher education: Forming whole and holy persons. Downers Grove, IL: InterVarsity Press. https://doi.org/10.1080/15363759.2017. 1316155

Gibbs Jr., R.W., Bryant, G. A., \& Colston, H. L. (2014). Where is the humor in verbal irony? Humor. International Journal of Humor Research, 27(4), 575-595. DOI: https://doi. org/10.1515/humor-2014-0106

Goor, R. van, \& Heyting, F. (2006). The fruits of irony: Gaining insight into how we make meaning of the world. Studies in Philosophy and Education, 25(6), 479-496.

Heslep, R. D. (2001). Habermas on communication in teaching. Educational Theory, 51(2), 191-207. https://doi.org/10.1111/j.1741-5446.2001.00191.x

Hooks, B. (2009). Confronting class in the classroom. In A. Darder, M.P. Baltodano, \& R.D. Torres (Eds.), The critical pedagogy reader (pp. 135-143). New York \& London: Routledge.

Isen,A. (2003). Positive affect as a source of human strength. In L. Aspinwall, \& U. Staudinger (Eds.), A psychology of human strengths: Fundamental questions and future directions for positive psychology (pp. 179-195). Washington, DC: American Psychological Association.

Kierkegaard, S. (1983). Repetition. (H. V. Hong, \& E. H. Hong, Trans.). Princeton, NJ: Princeton University Press.

Kierkegaard, S. (1985). Philosophical fragments. (H.V. Hong, \& E.H. Hong, Trans.). Princeton, NJ: Princeton University Press. 
Kierkegaard, S. (1987). Either/or, part 2. (H.V. Hong, \& E. H. Hong, Trans.). Princeton, NJ: Princeton University Press.

Kierkegaard, S. (1991). Practice in Christianity. (H.V. Hong, \& E. H. Hong, Trans.). Princeton, NJ: Princeton University Press.

Kierkegaard, S. (1992a). The concept of irony. With continual reference to Socrates (H.V. Hong, \& E. H. Hong, Trans.). Princeton, NJ: Princeton University Press.

Kierkegaard, S. (1992b). Concluding unscientific postscript to philosophical fragments (H.V. Hong, $\&$ E. H. Hong, Trans.). Princeton, NJ: Princeton University Press.

Kierkegaard, S. (1998). The point of view for my work as an author (H.V. Hong, \& E. H. Hong Trans.). Princeton, NJ: Princeton University Press.

Kierkegaard, S. (2002). Afsluttende uvidenskabelig efterskrift [Concluding unscientific postscript to Philosophical Fragments]. In N.J. Cappelørn, J. Garff, J. Knudsen, J. Kondrup and A. McKinnon (Eds.), Soren Kierkegaards skrifter [Søren Kierkegaard's writings], vol. 1-55. Volume 7. Copenhagen: Gads forlag.

Kierkegaard, S. (2003). Journal. In N.J. Cappelørn, J. Garff, M. Hansen and J. Kondrup (Eds.), Søren Kierkegaards skrifter [Søren Kierkegaard's writings], vol. 1-55.Volume 21 (pp. 143-195). Copenhagen: Gads forlag.

Koskela, J., \& Siljander, P. (2014). What is existential educational encounter? Paideusis, 21(2), 71-80. https://doi.org/10.7202/1071567ar

Lear, J. (2011). A case for irony. Harvard: Harvard University.

McCreaddie, M., \& Harrison, J. (2019). Humour and laughter. In O. Hargie (Ed.), The handbook of communication skills (pp. 287-317). New York \& London: Routledge.

Merriam-Webster. (2020). Communication. Available at: https://www.merriam-webster.com (accessed 17 November 2019).

Morreall, J. (2014). Humor, philosophy and education. Educational Philosophy and Theory, 46(2), 120-131. Doi: https://doi.org/10.1080/00131857.2012.721735

Nehemas, A. (1998). The art of living: Socratic reflections from Plato to Foucault. Berkeley: University of California.

Online Etymology Dictionary. (2020). Existence. Available at: https://www.etymonline. com/word/existence (accessed 15 September 2019)

Patton, T. O. (2020).Visual rhetoric. Theory, method, and application in the modern world. In S. Josephson, J. Kelly, \& K. Smith (Eds.), Handbook of visual communication theory, methods, and media. New York \& London: Routledge.

Platz, M. (2021). Trust between teacher and student in academic education at school. Journal of Philosophy of Education, 1-10. https://doi.org/10.1111/1467-9752.12560

Ruzgar, M. E. (2018). On matters that matter in the curriculum studies: An interview with Ian Westbury. Journal of Curriculum Studies, 50, 670-684. DOI: 10.1080/00220272.2018.1537374

Saeverot, H. (2010). Educative deceit: Nabokov and the [im]possibility of education. Educational Theory, 60(5), 601-619.

Saeverot, H. (2011). Kierkegaard, seduction, and existential education. Studies in Philosophy and Education, 30(6), 557-572.

Saeverot, H. (2013). Indirect pedagogy. Some lessons in existential education. Berlin: Springer.

Saeverot, H. (2015). Revitalising Bildsamkeit? Studies in Philosophy and Education, 35(1), $1-16$.

Saeverot, H. (2017). Pedagogikkvitenskap [Pedagogical science]. Bergen: Fagbokforlaget.

Saeverot, H. (2019). Indirect teaching. In J. Baldacchino, K. Freedman, \& R. Hickman (Eds.), International encyclopedia of art and design education, Volume 3: (pp. 1-13). Hoboken, NJ: John Wiley \& Sons. 
Saeverot, H. (Ed.) (2021). Meeting the challenges of existential threats through educational innovation. A proposal for an expanded curriculum. New York \& London: Routledge.

Saeverot, H., Reindal, S., \& Wivestad, S. (Eds.) (2013). Special issue. Existentialism and education. Studies in Philosophy and Education, 32(5)

Saeverot, H., \& Torgersen, G.-E. (2021). SSE-based frame of reference. Outlines for a global curriculum: Turning existential threats into resources. In H. Saeverot (Ed.), Meeting the challenges of existential threats through educational innovation. A proposal for an expanded curriculum (11-26). New York \& London: Routledge.

Smeyers, P. (2005). Idle research, futile theory, and the risk for education: Reminders of irony and commitment. Educational Theory, 55(2), 165-183.

Smith, R. (2011). The play of Socratic dialogue. Journal of Philosophy of Education, 45(2), 221-233.

Smith, R. D. (2016). The virtues of unknowing. Journal of Philosophy of Education, 50(2), 272-284.

Smith, R. (2020). Unsettling knowledge. Irony and education. Journal of Philosophy of Education, 53(3), 757-771. https://doi.org/10.1111/1467-9752.12444

Stenseth, N. C. (2021). Foreword. In H. Saeverot (Ed.), Meeting the challenges of existential threats through educational innovation. A proposal for an expanded curriculum (xvii-xx). New York \& London: Routledge.

Szkudlarek, T. (2021). Ignorance and truth. In H. Saeverot (Ed.), Meeting the challenges of existential threats through educational innovation. A proposal for an expanded curriculum (196210). New York \& London: Routledge.

Torgersen, G. E. (Ed.). (2015). Pedagogikk for det uforutsette [Pedagogy for the unforeseen]. Bergen: Fagbokforlaget.

Torgersen, G.-E. (Ed.) (2018). Interaction: 'Samhandling' under risk. A step ahead of the unforeseen. Oslo: Cappelen Damm Akademisk.

Tyson, L. (2015). Critical theory today: A user-friendly guide. New York \& London: Routledge.

Vlastos, G. (1991). Socrates, ironist and moral philosopher. Cambridge: Cambridge University Press.

Vasiliou, L. (2002). Socrates' reverse irony. The Classical Quarterly, 52(1), 220-230. Doi:10.1093/cq/52.1.220

Walsh, S. (2009). Kierkegaard. Thinking Christianly in an existential mode. Oxford: Oxford University Press.

Wanzer, M., Frymier, A., \& Irwin, J. (2010). An explanation of the relationship between instructor humor and student learning: Instructional humor processing theory. Communication Education, 59(1), 1-18.

Ziv, A. (1988). Teaching and learning with humor: Experiment and replication. The Journal of Experimental Education, 57(1), 5-15.

\section{Films}

Knopp, G. (Director). (1996-1998). Hitler's Generals [Hitler's Helfer] (documentary film).

\section{Painting}

Vouet, S. (1617). The fortune teller (painting). Available at: https://commons.wikimedia.org/ wiki/File:Vouet,_Simon_-_The_Fortune_Teller.jpg (accessed 2 May 2020). 


\section{Ethics}

\section{Where is the boundary between the ethical and the unethical regarding teachers' indirect actions? A case study}

The theme of this chapter is ethics. As I have already shown through argumentation, indirect communication used in teaching may be unethical to various degrees. In the previous chapter, I showed several examples of this. For example, irony may suppress, while deceit and seduction can be used to gain benefits. Undoubtedly, certain indirect forms of communication can be unethical if they are used without caution. However, when indirect communication and strategy are used, it is not always easy to spot the boundary between what is ethical and unethical. To illustrate this, I will reflect upon a particular case on bullying at a lower-secondary school from a Levinasian perspective on responsibility for the other and justice for all others.

\section{What is bullying?}

What is bullying? Olweus (1993) defines bullying as repeated aggression directed at individuals who are less powerful. Although Olweus' definition is the most widespread in the world, there are various definitions of bullying in the scientific literature, and debates about what bullying is and how it could be prevented are still going on (see e.g. Canty, Stubbe, Steers, \& Collings, 2016; Carrera, DePalma, \& Lameiras, 2011; Ellwood \& Davies, 2010; Frånberg \& Wrethander, 2011; Kousholt \& Fisker, 2015; Ringrose \& Renold, 2010; Schott, 2014; Volk, Dane, \& Marini, 2014). In particular, the intention of harm has been problematised. Bullying might for instance take place among students who interpret actual bullying as a harmless joke or play. This is an example of indirectness, as the bullying is received as something else, as either a joke or play. Thus, there are cases, due to indirectness at play, in which it is problematic to determine "where the joke ends and the abuse begins" (Carrera et al., 2011, p. 486). Overall, school bullying is a complex phenomenon with multiple causes and risk factors, ranging from individual characteristics to school settings to broader social contexts (Barboza et al., 2009; Espelage, 2014; Espelage \& Swearer, 2004, 2011).

Both individual and contextual factors, and how they might interplay to produce bullying, are considered and examined in the international field of the mainstream research on school bullying and cyberbullying, in which developmental and educational psychological perspectives are still dominant but in dialogue with scholars and frameworks from other disciplines and fields such as criminology, 
social work, health sciences, educational research and sociology (see e.g. Hong \& Espelage, 2012; Zych, Farrington, \& Ttofi, 2018). Despite all these perspectives, the pedagogical perspective has largely gone unexamined, in public debates and in research (Thornberg, Baraldsnes, \& Saeverot, 2018). It is important to stress that bullying in school is a complex phenomenon, which requires a broad focus on different systematic factors, including the pedagogical perspective. Teachers play an important role in creating a positive school environment and directly influence students' educational, social and emotional outcomes (VanZoeren \& Weisz, 2018), including the prevalence of bullying (Roland \& Galloway, 2002). Research also shows that teachers are "key agents of change" (Kallestad \& Olweus, 2003, p. 19) and should be considered as the most crucial professionals in bullying intervention (Batsche \& Knoff, 1994; Bradshaw, Sawyer, \& O’Brennan, 2007; Hektner \& Swenson, 2012; Veenstra, Lindenberg, Huitsing, Sainio, \& Salmivalli, 2014; Yoon \& Bauman, 2014; Yoon \& Kerber, 2003; Yoon, Sulkowski, \& Bauman, 2016). The following case shows how a teacher tried to solve a bullying situation through direct and indirect means. Let us take a closer look at this case.

\section{The case}

The case I will reflect upon stems from an event on bullying that occurred in a Norwegian lower-secondary school in the 1980s. The event was later documented in a Norwegian newspaper, Bergens Tidende, on January 29, 2011. Journalist Trine Eilertsen wrote the article, entitled "Teacher Bjørndal's Method." Here is the English version (my translation):

There is a knock on the door to class 9B. They are about halfway through a lesson in Norwegian. Their form master stands outside the door. When the class sees him, they sit up straight. He has that effect on them, and they know it must be serious as he calls on them in the middle of another teacher's lesson.

"I would like to speak to Arne, Per, Lise, Ingrid, Gunnar and Tone. You will come with me to a study room, now."

The named students exchange questioning looks, stand up and leave the classroom.

"Sit down," says the form master curtly after closing the door behind them in the study room. "And listen carefully."

"Else did not come to school yesterday. And she is not here today. She is at home. Her stomach hurts so much that she cannot come to school. I just spoke to her mother, who told me that Else has felt this way all autumn semester."

The students look insecurely at the teacher, then at each other, but recognise what he is telling them.

"Else is not coming to school because she hates being here. You, among others, are responsible for this."

"Us? But none of us have ever..." Lise says in defence. 
Once there was a teacher. He knew who to speak to when one of his students was bullied at school.

"No, none of you have tormented Else.You're not the ones that make fun of her when she has to read out loud in class, pushing her, or commenting on her looks. Rune and Egil are the ones doing that. No, you are responsible because you do nothing to stop it. What you have in common is that you are the most respected pupils in your class; best at sports and physical education, best grades, good at football, and just popular among everyone. No one has greater power than you in your class. But you use the power for your own glory, not to prevent Else from being bullied by those who need someone weaker than them to pick on.Your power is not used to help her to participate and be included. It's pathetic, and I am very disappointed in you,' says the teacher.

The students stare at him, then down at the table. They blush. They have been familiar with a certain feeling. They thought of saying something but didn't. They can't say anything now. The teacher continues:

"I expect you, especially you, to take responsibility," he says, slamming his hand on the table. "I expect you to sort it out, and to do what you can to stop this. And you will do so without telling anyone we had this conversation. The conversation is between us, and God have mercy on you if I hear anything about it outside this room!"

A few days later, the class is having another lesson in Norwegian. A weak teacher has once again been persuaded by Egil to have Else read out loud. Her cheeks are flushing, she is stuttering, have trouble starting. Rune laughs out loud and shakes his head. At that moment, Arne, the top athlete in the class, stands up. He points to Rune and says: "You! Shut up, you idiot!"

Rune does shut up. He has been told in a language he comprehends, by an authority he understands.

The small group of students from the study room never speak of that meeting they had with the teacher they respect so highly. They just try to be an influence wherever they can. The pressure on Else imperceptibly becomes lighter and lighter, but the students from the group take little pride. They will feel shame for the rest of their lives for not intervening sooner.

I know this, because I was in that room that day, sometime in the mid-1980s. I sat there and listened to the legendary teacher Øyvind Bjørndal, whom our class respected deeply and sincerely, as he thoroughly knocked some sense into me and several of my friends as we had neglected our responsibilities.

I have thought of this episode many times over the years. Bjørndal's method was so effective, and yet so simple. It is impossible to forget a wake-up call like that, and it does something to your sense of responsibility for the rest of your life.

Else can thank Øyvind Bjørndal for making her life a little easier. But we, who were present in that study room, may have even more reason to thank him. 


\section{An exemplary method?}

The article turned out to be a great success for the general public. It was the newspaper's most shared article of all time and the most-read piece on the newspaper's website. On Facebook, the article has been shared by several thousand users. Many were moved by the story, and among them was Norway's former prime minister and current secretary-general of NATO, Jens Stoltenberg, who shared the article on his Facebook page. Overall, “Teacher Bjørndal's Method” has been presented, outside the research community, as a happy story and a model of dealing with bullying. Eilertsen, too, views this method ${ }^{1}$ as an exemplary method of how to solve the problem of bullying. She describes it as "so effective, and yet so simple," regarding it as "making [Else's] life a little easier." The story of bullying seems to have a happy ending, although we as readers do not really know how Else's and the others' lives played out after Bjørndal's intervention in the bullying situation.

\section{Is Bjørndal's method just to all the students involved?}

The newspaper article is merely a story being told indirectly to the reader, after which the factual events occurred. This is Eilertsen's story, and it is her perspective we are presented with. Even if she was one of the six students selected by Bjørndal, we cannot properly discuss the actual teacher Øyvind Bjørndal. We know nothing of him and do not know what really happened. We have only Eilertsen's version at our disposal, and questions are left hanging in the air. Was the problem solved once and for all? How did 'the victim' of the bullying, Else, get on? What happened to those who are considered as bullies, Rune and Egil? How did this affect the six chosen students? We do not really know, as Eilertsen provides too little information for hardly anything but speculation.

What we can reflect upon, though, is this particular question: Is teacher Bjørndal's method ethically legitimised? To address this question, I will turn to the ethics of Emmanuel Levinas (1906-1995). Responsibility for the other is at the heart of Levinas' ethics (Levinas, 2003, 2009). Responsibility is not something you prethink or simply decide to conduct. The responsibility strikes us as an event, not as an acknowledgement. Responsibility, like other events in life such as love, birth and death, comes to us from the outside as something that happens to us (Thomassen, 2016). It is about responding to the one who calls you. In this case, it is the 'victim' Else who calls teacher Bjørndal, who has chosen to respond in his own way. However, the relationship with the other is complicated as soon as 'the third' or others are involved; in other words, the responsibility for the other is disturbed and becomes a problem when the third arrives (Saeverot, 2015). It is no longer just about responsibility, but also about justice. When the third arrives, in this case the two 'bullies' and the six chosen students, Bjørndal is not only faced with the immediate responsibility for Else, but he is also faced with the demand for justice for all the involved students. When the third enters the relationship, in addition to the other, Bjørndal must respond to all the students, not just Else. The question is whether Bjørndal is just to everyone, or to put it more precisely, is Bjørndal's method just to all the students involved in the bullying case? 
How may we understand justice in the light of Levinas? This is a comprehensive question that normally requires a lot of space, but since I do not have much space available, I will try to answer as briefly and concisely as possible. For Levinas, justice presupposes an encounter with the face, as the face reveals the third, or the relationship between Bjørndal and Else, 'the bullies' and the six chosen students (cf. Levinas, 2003, p. 213). At the arrival of the third, the relationship finds its form by way of conscientious considerations of reasonableness among various alternatives of action (Levinas, 2003, p. 84, 101). One can therefore not decide in advance what is just (Levinas, 2009, p. 159). Justice is shown through encounters with faces, and from there, it is the conscience that considers the reasonableness regarding various alternatives of action. In addition, the law or the rules and principles that apply to the case, in this case bullying, come into play. The call to justice is a call to think of the abstraction of law together with the uniqueness of every face (Roberts-Cady, 2009).

My task is to analyse the newspaper article closely, together with theory and legislation, so as to be able to grasp what is revealed with regard to the overall question, whether Bjørndal's method is just to all the students involved. The overall question will be supplied with the following supporting questions, which can help us to see if Bjørndal is just or not. What does Bjørndal's method look like and why did he choose this particular method? What signifies Bjørndal's form of communication? Who is responsible for preventing bullying? What are the repercussions of Bjørndal's method and means?

\section{Indirect method}

One of the most important functions of education is to teach students to take care of each other, and show solidarity and humanity (Klafki, 2001). This is practiced in different ways in different school subjects. For instance, schools work to prevent bullying through anti-bullying programmes, such as the Olweus method (Thornberg et al., 2018). Programmes like this did not exist in the 1980s when Bjørndal was teaching. In a contemporary perspective, he chose an unorthodox method, that is, an indirect method.

\section{Bjørndal's unorthodox and indirect method}

After speaking to Else's mother and learning that Else's stomach hurts so much that she cannot come to school, teacher Bjørndal chooses to approach six students: Arne, Per, Lise, Ingrid, Gunnar and Tone (Trine Eilertsen is one of these; see e.g. Hein, 2017, for new perspectives on the positioning of parents in children's bullying at school). These students are seen as the most respected in their class; "best at sports and physical education, best grades, good at football, and just popular among everyone. No one has greater power than you in your class.” Bjørndal takes an indirect approach. That is to say, he seeks out these resourceful students, rather than going directly to 'the bullies.' Bjørndal tries to unite a group of students, based on their status and popularity, to indirectly affect and improve Else's situation. In other words, 
Bjørndal creates an indirect bridge between himself and the six chosen students. Thereafter, one of the 'bullies,' Rune, is involved in the following attempt at solving the bullying situation. Eventually, everything and everyone surrounding Else contribute to improving her situation (at least that is how it is presented by Eilertsen).

\section{Why did Bjørndal choose an indirect method?}

Bjørndal must have faced many different options as to what strategy and method he would choose (see e.g. Yoon et al., 2016, how teachers tend to respond to bullying incidents). For instance, he could have chosen to speak directly to Rune and Egil, to take immediate control of the problem. He might have tried this, but we do not know. What we do know is that he chose an indirect route, aiming to reach 'the bullies' through an intermediary, which in this case was a group of students whom 'the bullies' likely respected. Bjørndal apparently realises that he cannot speak directly to 'the bullies,' probably because his authority would not help in this case. He needed an authority that could touch and affect 'the bullies' in such a manner that the bullying would come to an end. In light of this, it is beneficial to select six students, including both boys and girls, who are respected in the class. It all seems to be a crafty plan, as Bjørndal, due to the indirect strategy, gains the upper hand over 'the bullies.'

Above all, Bjørndal stands behind his "troop" with all his influence and authority, acting indirectly through the six students, who each are respected by the other students, perhaps including 'the bullies.' It would not be easy to go against such an authority. The number of students is also meaningful in this case. A group of six students is established, with Bjørndal in the background, against two 'bullies,' each of whom is weaker than each of the six. The fact that both sexes are represented in Bjørndal's "moral police" may also be meaningful in this context, as the group can appeal to both sexes. In certain situations, the opposite sex can have a stronger influence, though this depends on several factors (see, e.g., van Hek, Kraaykamp, \& Pelzer, 2018, a study that shows that girls have a positive influence on boys in the classroom). One may think that it might be an advantage to let the girls go against Rune and Egil, so as to prevent Else from being bullied. However, this is far from guaranteed.

\section{Direct communicative form}

What signifies Bjørndal's form of communication? By looking at the form of his communication, we can possibly find an answer as to whether he answers the third, the other students, in a just way. For example, does his form of communication allow the students to have a say in the case? The answer to the question on his form of communication may lie in the fact that Bjørndal is highly respected. The students sit up straight when they see him, and he can use this authority in his interaction with the six students. Thus, he can allow himself to be direct in his communicative form, as opposed to his underlying, covert strategy, which is more indirect. 


\section{Commanding tone}

To begin with, he almost pulls the six students out of the classroom. In a commanding tone, he says, "You will come with me to a study room now." Inside the study room, he continues to command: "Sit down [...]. And listen carefully." We can safely say that he is stern and angry, and the situation must have felt uncomfortable to the six students. This feeling is likely intensified when Bjørndal informs them of Else's situation. He then moves on to condemning the six as accomplices to the bullying. He does not say directly that they are culpable, but he emphasises that "you are responsible because you do nothing to stop it." He goes on: "You use the power for your own glory, not to prevent Else from being bullied [...]. It's pathetic, and I am very disappointed in you."

The six students are obviously strongly shaken and upset by this. Their bodies react by blushing. Shame fills them, and they can no longer look at him, but stare down at the table. They say nothing. Lise did try to say something early on but was quickly interrupted by Bjørndal (see e.g. Bradshaw et al., 2007, that shows perceptual differences in bullying between students and school staff). They submit to Bjørndal's judgement through their body language and their silence.

Bjørndal disregards this while commanding, "I expect you, especially you, to take responsibility." As he says this, he slams his hand onto the table, hence reinforcing the words' commanding tone through a physical gesture. The words are further reinforced when he repeats what he expects of them. Finally, Bjørndal says, "God have mercy on you if I hear anything about it outside this room!" The words "God have mercy on you" imply a threat of punishment if they do not do as he commands.

Overall, Bjørndal's communicative form is very direct and strong, and in part judgemental, commanding and threatening. These are clear signs that he is not responding to the students in a just way. By this we start to perceive that Bjørndal's method does not seem to be an exemplary model as it is claimed to be when it comes to solving the problem of bullying.

\section{Discontinuous education?}

From another point of view, Bjørndal's method may resemble a kind of discontinuous education. In his book Existentialism and Education, first published in 1959, Otto Friedrich Bollnow (1903-1991) introduces a discontinuous form of education, as a supplement to a continuous education, which advances progressively and continuously (Bollnow, 1976; see also Koerrenz, 2017). For instance, the teacher can, in various ways, cause discontinuous interruptions in the student's indifferent and unfruitful modes of existence. This is evident where Bollnow (1976, p. 75) emphasises that it is necessary to touch Man to its core. Bollnow presupposes that people at times may find themselves in indifferent and inauthentic states of being, that they need to be pulled out of.

There are three aspects of Bjørndal's method that resemble Bollnow's discontinuous education. Firstly, Bjørndal interrupts the class. There is a sudden interruption in an ongoing lesson. This is a discontinuous event. Secondly, Eilertsen calls 
Bjørndal's method a "wake-up call.” Awakening is a central means of education in Bollnow's educational theory (Bollnow, 1976; Koerrenz, 2017). As for teacher Bjørndal, he tries to awaken the group of popular students so as to take responsibility for their classmate who is being bullied. Thirdly, Eilertsen acknowledges that "we had neglected our responsibilities." In such cases, Bollnow (1976) speaks of the importance of admonition, which is a means of education, being used to awaken the self-sufficient ones. But is Bjørndal's method a case of admonition?

Eilertsen provides a hint when she points out that Bjørndal "thoroughly knocked some sense into me and several of my friends." In this way Bjørndal's attempt at awakening his students is close to a command, as manifested by both his words and body language (cf. the hand slamming onto the table). Bjørndal even blames the group for not taking responsibility sooner, while he expects them to set it straight.

Thus, the difference between Bjørndal's education method, which is practiced in actions, and Bollnow's education method, which is theoretical, becomes clear. In Bollnow's (ibid.) concept of admonition, we find a choice. The admonished can choose whether or not to take the admonition to heart. This choice does not exist in Bjørndal's form of communication, with its accusatory and commanding tone. Bjørndal does not address a free will. He treats the students unjustly by solely guiding them through his own thoughts and principles. He almost coerces his students and certainly does not give them a choice. This is certainly not appropriate in a modern school, which should base its educational endeavour on the free will of the students.

So far, we have gained insight into Bjørndal's indirect strategy and communicative form. I will revisit his indirect strategy later and evaluate whether or not it is ethically justifiable. When it comes to his form of communication, he seems to go too far in an unjust direction, which can be substantiated when we ask ourselves who is really responsible for putting an end to the bullying. By that I will introduce 'the law' or the rules and principles that apply to bullying in school. According to Levinas, this 'law' must be thought of together with the uniqueness of every face (Roberts-Cady, 2009). The question is whether Bjørndal does this.

\section{Who is responsible for preventing bullying?}

As for the question of who is responsible for the bullying of Else, it is easy to point directly to Rune and Egil, who are considered as the actual bullies. However, we cannot see that Bjørndal chooses to directly confront the two 'bullies.' Instead, he contacts those students who are, according to him, accomplices, as they have done nothing to intervene in the bullying situations. But are students responsible for preventing bullying?

\section{Is it the students' responsibility to prevent bullying?}

From a certain ethical standpoint, it may be claimed that the six students benefitted from having the responsibility of solving the bullying. Eilertsen herself implies this when she says, "We, who were present in that study room, may have even more 
reason to thank him." And perhaps Bjørndal's handing over the responsibility to the six students can be justified in the light of history, which shows that humankind constantly fails to take responsibility, while conducting different forms of cruelty. Giving resourceful youths a bit of guilty conscience surely is not wrong? Is this not a price worth paying to end the bullying? Despite the rather brutal nature of Bjørndal's approach, can we not understand and acknowledge his reasoning? Is he not right that only the most resourceful, high-status students have enough power in their class to stop the unacceptable behaviour? Besides, if we look past Bjørndal's rather ruthless and unjust method, we can catch a glimpse of recognition of the six students. By giving the six students the responsibility, he shows faith in them, which may be one of the most important qualities of a teacher (cf. Benner, 2012).

From another ethical standpoint, we can wonder why Bjørndal seemingly does not take responsibility himself. Instead, he hands over the responsibility to the six students. Bjørndal wants them to take responsibility for solving the bullying problem. By doing so, he ignores the responsible role of a teacher. The point is not to say that the six students are without guilt. Eilertsen's article gives the impression that the students themselves realise that they are complicit. They feel guilty when Bjørndal claims they are responsible for what has been happening in their class and that they could have been there for Else and contributed to ending the bullying. Even so, is it right to impose this sort of responsibility on these youths?

When all is said and done these students are not responsible as long as they are part of a modern school. The school management and teachers are responsible for solving bullying. Admittedly, bullying was not given much attention from the governments in the 1980s, and the delegation of responsibility was not yet established by law, as is the case today. For example, the Education Act, paragraph 9a-3, states that problems of bullying are the responsibility of the school, and the 22nd Report to the Storting (white paper) (2010-2011, p. 73) points out the following (my translation): "School management, teachers and other adults in schools must make it clear that they are the ones who are responsible for preventing bullying from happening in their school."

Although the Education Act did not exist in Bjørndal's day and the delegation of responsibility was not yet explicitly stated in political documents, no excuse can be made for him. The fact that school management, teachers and other adults in schools are responsible for preventing bullying is ingrained in education itself. Being a teacher does not only entail a responsibility for learning but also for protecting children against harmful content. This was pointed out by educationists and others centuries ago, for example in Rousseau's famous novel Emile, or On Education from 1762 (Rousseau, 2003).

Thus, we cannot get past the fact that it is the responsibility of Bjørndal, the school management and other adults to prevent bullying from happening at their school. Bjørndal has no right handing over the responsibility for preventing the problem of bullying to a group of students. These students only became pawns in a manipulative game played by teacher Bjørndal. Thus, we have another sign that tells us that they are not being treated justly. 


\section{Delegation of responsibility with no educational training}

From yet another ethical point of view, it is a good thing for students to be given responsibilities. However, the extent and kinds of responsibility should be considered carefully beforehand, based on a number of factors. There should also, from an educational perspective, be provided forms of training when those who are given responsibility are unqualified or lack experience and knowledge. The way the story is presented to us readers, Bjørndal gives the students a form of responsibility that they are incapable of practicing in an ethically appropriate manner, as if medical doctors were to leave it to their patients to find the right medications for another patient's illness.

It goes without saying that this sort of choice can have dire consequences. And, indeed, Eilertsen's article implies that something is going wrong. "You! Shut up, you idiot!'The words are uttered by Arne, directed at one of 'the bullies.' Can Arne be blamed for this, as we would not blame someone for not understanding a text in a language they have not yet learnt? Or should Arne and the other students have been provided with some tools from Bjørndal - that is, some concrete advice or guidance to help them practice their responsibility in an ethical and just manner?

\section{The repercussions of Bjørndal's method and means}

But what is the problem? Is there, in fact, any problem with Bjørndal's method? Does it not seem to solve the problem of bullying? Do the ends not justify the means? To address these questions, some light should be shed on the repercussions of Bjørndal's method and means with regard to all the parties in this case, that is, 'the bullies', 'the victim' and the six students. Can we, through such a perspective, see that Bjørndal acts justly or not?

\section{'The bullies' and 'the victim'}

What if 'the victim' of the bullying, Else, had found out about this? Or what if the subject matter of the conversation between Bjørndal and the six students had been leaked to their classmates? According to Eilertsen's article, there is no indication of the other students learning what happened in that study room. The six students were bound to secrecy by Bjørndal, and according to Eilertsen, they never spoke of what happened in the study room (that is, until Eilertsen published her version in the newspaper). Still, there was no guarantee that one or more of the six students would not break the obligation of secrecy. One can only assume that the situation made the rest of the class curious, considering that Bjørndal interrupted a lesson to pull six students out of the classroom. In other words, it is not unlikely that the remaining students would want to know what was going on. Bjørndal's method is indeed a risky undertaking. He could easily have been exposed for having used his students as pawns in his manipulative game. This also puts the trust between the involved parties at risk. The chance of a breach of trust between Bjørndal and his students is close at hand.

At the same time, Bjørndal's method involves a lot of parties who must be answered in a just manner. If not, it can easily cause unfortunate ripple effects. This is shown in 
Eilertsen's newspaper article. As Bjørndal tries to put out one "fire," he adds fuel to another. This can lead to a spread of "fires" or conflict situations in addition to the original conflict. A conflict can, for instance, arise around 'the bullies' Rune and Egil. Eilertsen's article hints at this, as we have already seen. Arne, the class athlete, stands up and reprimands Rune ("You! Shut up") while stigmatising him ("you idiot!"). Some may think that this was well deserved because of Rune's bullying of Else. Eilertsen herself gives the impression that Arne's comment was legitimate and acceptable: "Rune does shut up. He has been told in a language he comprehends, by an authority he understands." Rune's authority is, in this situation, surpassed by Arne's authority, which is made even stronger by the support of the authority of the other members of the "moral police." However, what Eilertsen does not bring up is the fact that someone is suppressed by an authority exercising a sort of power. In this case, Rune is suppressed and treated unjustly by Arne's use of power.

\section{Power as an indirect educational means}

Power is precisely the means Bjørndal indirectly wishes to use to solve the bullying problem. According to Eilertsen, he says the following to the six students: "No one has greater power than you in your class. But you use the power for your own glory, not to prevent Else from being bullied by those who need someone weaker than them to pick on." In the last part of the sentence, Bjørndal stigmatises 'the bullies' by emphasising that they are weak and therefore need to pick on someone weaker than themselves (see e.g. Eriksen, 2018, which shows that a certain understanding of bullying can be a potent power for teachers and students). The reason that Bjørndal has picked these six students is clear. He wants someone with greater power than 'the bullies' to use their power to prevent the bullying. And that is precisely what Arne does when he stands up and stops Rune from speaking.

Is that where we want to go? Do we want a school based on a hierarchical order, where one power trumps the other? Should we move away from the idea that schools are to be based on humanistic and democratic values, including responsibility and justice for others? This power hierarchy may be of help in Else's situation, and that is of course a good thing. Nonetheless, we must not hide the fact that teachers have many considerations to make. When Arne reprimands Rune, this creates a division, not only between the two of them but perhaps also between 'the bullies' and the six chosen students, perhaps even between others. From that perspective, the ends do not justify the means.

In contrast, and as pointed out in Chapter 2, an educational approach would be based on goals related to both the individual and the world so that everyone is cared for in a good way (Kemmis, 2012). Teachers should be interested in that which is good for each and every student (including Elsa, Rune and Egil), as well as that which is good for the world (the class, the school and so forth). In light of Levinas $(2003,2009)$, it is about being both responsible for the other and just for the third. Teachers should therefore strive to ensure that no student is oppressed and treated unjustly by the power wielded by other students, whether that be Else, Rune, Egil or any of the others. Though Bjørndal errs on this point, we are left 
with the impression that he wants to create a class in which the students afford each other opportunities. We can see this in the way he encourages the six students to "help [Else] to participate and be included."

Thus far, we have looked at the repercussions of Bjørndal's method and means in relation to Else, 'the victim' of the bullying, and the two 'bullies', Rune and Egil, as well as the class as a whole. However, we may also discover that Bjørndal's method and means have unjust repercussions for the six chosen students, in the form of adoption, shame and dependence.

\section{Adoption}

Firstly, we may ask ourselves whether Arne may have adopted teacher Bjørndal's commanding, judgemental and, indeed, unjust form of communication. The background for saying so is that the most effective form of education is perhaps what adults do, both consciously and unconsciously. Children imitate and often adopt what they observe in adults, for better or worse (cf. Corriveau, Min, Chin, \& Doan, 2016). How often have we not seen that children resemble their parents, both in language and posture? In such cases, it is obvious that the children have observed their parents' actions and adopted these as their own personal expressions.

As for teacher Bjørndal, he is an authority figure in the eyes of his students. Eilertsen describes him as "a legendary teacher [...] whom our class respected deeply and sincerely." And "[w] hen the class sees him, they sit up straight. He has that effect on them." Bjørndal clearly has a strong influence on the six students. At least that is the impression Eilertsen gives when she points out that she and the rest of the group that was 'hired' as the 'morality police' have taken on and executed the task: "They just try to be an influence where they can." Given this background, it is not unlikely that Arne and the other students in the group adopted Bjørndal's communication form and way of being, which have, so to speak, functioned as their inner compass.

\section{Shame}

Secondly, there are reasons to question the shame the students are subjected to by Bjørndal. Eilertsen writes, "[T] he students from the group take little pride. They will feel shame for the rest of their lives for not intervening sooner." Is it ethically justifiable to subject these six students to a shame so strong that, according to Eilertsen, it will be lifelong? Does this not tell us that Bjørndal has been too hard on them? For sure, we all need a wake-up call from time to time; however, this wake-up call has been too strong, and partly unjust, as they feel ashamed of something they were not responsible for and apparently had not been trained to handle.

\section{Indirect coercion and responsibility based on a third person}

Thirdly, we may ask whether Bjørndal's emotionally charged actions deprive the student's freedom of choice and their right to respond without being constrained by an external party. This question relates to the fact that his approach centres 
around himself in two ways: (1) He appeals to their feelings: "I [!] am very disappointed in you." (2) He expects them to take responsibility: "I [!] expect you, especially you, to take responsibility .... I [!] expect you to sort it out." By doing so, and by exploiting his authority by beginning the sentences with 'I,' he can put strong pressure on the six students.

To be fair, though, Bjørndal offers them a choice, but the question is whether this is a real choice. The situation is thus: if the students do not follow his orders, he will likely be even more disappointed, and they will probably lose his recognition. They are therefore indirectly coerced to do what he says. Indirectly, Bjørndal appears to say the following: "By following my orders, that is, take responsibility for Else's situation, you can sweeten me up so that I will not be disappointed in you anymore."

If the six students do what Bjørndal says - which they in fact do- they are not acting out of their own free will. They are acting because Bjørndal tells them to do so. Though they do take responsibility, they only do so because Bjørndal has more or less demanded them and perhaps because they do not want to lose his approval. Bjørndal's overly direct actions, therefore, appear to create a dependence on him as a third person. Instead of taking responsibility from a first-person perspective, in which the students can respond on a free and independent basis, they become dependent on, and constrained by, Bjørndal. How just is that?

\section{Is Bjøndal's method ethically legitimised?}

From a general perspective, the solution to the bullying described earlier was considered to be exemplary. That is in a sense understandable, given that many victims of bullying have their lives ruined. Some victims of bullying even commit suicide. In such a context, teacher Bjørndal seems to be a hero, as he appears to prevent the bullying from happening in his class. He has taken responsibility for the other, Else, but has he been just to the other students involved?

In contrast to Eilertsen and everyone who has commented on the text on social media, I chose to frame the bullying from an ethical perspective. In a Levinasian perspective, teacher Bjørndal stands in the tension between the other (Else) and the third (the other students involved), between responsibility and justice (Levinas, 2003 , 2009). From this perspective, I found that teacher Bjørndal plays a dangerous game and that he indeed plays with the students' fate. He tries to solve a bullying problem through a creative and cunning method, with lack of ethical assessment (cf. Neher, 2020).

Bjørndal also attempts to implement an indirect form of practical pedagogy, but the intermediary approaches that he uses are completely out of control. As I pointed out in Chapter 1, in many contexts, indirect pedagogy can be very beneficial, but in this case, its use must be questioned-especially when Bjørndal uses children as intermediaries in relation to the bullying problem.

Furthermore, Bjørndal's strict and overly direct forms of communication do not provide space for the students' views of the problem. Should he not at least have asked the students first, and let each of the six students express their views of the problem? According to Eilertsen's article, Bjørndal does not do so. Instead, he 
seems to interrupt Lise before she even completes her sentence. While it is fairly clear that Lise wants to deny responsibility ("Us? But none of us have ever..."), one should ask whether Bjørndal made the right decision in interrupting her. Should she not be allowed to speak, as an initiation for a just conversation?

Eilertsen's newspaper article also gives the impression that there is a lack of training for a task that comes with a lot of responsibility while requiring experience and expertise in disciplines such as education, psychology and ethics. The task, therefore, does not appear to be executed in an ethically legitimate manner-quite the contrary. The students are treating each other unjustly as they are telling each other off and commanding each other to shut up.

Bjørndal, who pushes his students forward, is responsible for these unjust occurrences. As a teacher, one must take many considerations into account, including the needs of those who are described as bullies. For some, this may sound like excessive kindness, but is it fair to put all blame on 'the bullies,' considering that bullying is a complex phenomenon? In the final instance, it is Bjørndal's responsibility to handle the problem of bullying in his class. Bjørndal must respond to the bullying problem as a whole. He cannot only answer the other, 'the victim,' but he must also answer all the students involved. He has not extended the responsibility for the other to be applied for the others. Bjørndal's method is thus not just to all the students involved.

The following remark should nevertheless be added. As teachers stand in the tension between responsibility and justice, between the other (Else) or the uniquely individual, and the third (the other students involved), they also stand in what Rossiter (2011) refers to as an "unsettled practice." This means that teachers must accept being in insoluble dilemmas. Achieving absolute justice for all is impossible, yet it is what teachers and everyone else must always strive to achieve.

\section{Could Bjørndal have acted indirectly in an ethically legitimate manner? A hypothetical alternative to Bjørndal's method}

What if we now look at the aforementioned event that occurred in lower-secondary school hypothetically? How could a teacher hypothetically have acted indirectly in an ethically legitimate manner? There are many options as to how bullying may be prevented and reduced (see, e.g., Espelage, 2014; Hansen, 2014; Kousholt \& Fisker, 2015; Roland \& Galloway, 2004; Veenstra et al., 2014). It depends, inter alia, on the chosen perspective. My perspective, which is a starting point for further reflection and discussion, not an attempt to solve the bullying case, starts as follows: Could Bjørndal have shown 'weakness' instead, without being manipulative (see Biesta, 2014, for an elaboration on the concept of weak education)?

In other words, could he have been honest and shown his true feelings, at least to some of the students - perhaps in the form of grief and vulnerability? Turning the situation upside down like this, from power to 'weakness,' one may imagine a teacher who humbly shows his grief to the students-grief over Else's situation and perhaps sadness about the things he has not achieved. The teacher could have 
assumed full responsibility, without being judgemental, and at the same time made himself vulnerable and showed himself as 'weak' in front of the students.

Although it is impossible to know the outcome of such an approach beforehand, as many factors will be at play in a real, practical situation, including the students, timing, context etc., one may assume that showing 'weakness' in this way is to go quite far out on a limb. There is a chance that the whole thing will fail. For example, the teacher may lose his authority as a result of his obvious vulnerability.

On the other hand, there is also a possibility that the teacher's 'weak' approach may succeed, at least to a certain degree. For example, the explicit vulnerability may indirectly touch the students, or perhaps some of them, to become aware of something they actually know but have thus far not acknowledged, perhaps because they have remained in a state of moral slumber. The students are thus given the opportunity to see Else's hopeless situation through the teacher's grief, which then functions as an indirect intermediary. It should not go unnoticed that there is a danger of manipulating the students, by exploiting the grief (which is then dishonest).

What we perhaps can say with greater certainty than these assumptions is that the 'weak' teacher may act indirectly, without being coercive. There are basically two ways of being indirect, which I discussed in Chapter 2. On the one hand, it is possible to be indirect and simultaneously directly summon the other party to respond in a certain manner. This easily leads to a kind of coercion. On the other hand, a teacher who shows vulnerability can have an indirect effect without directly summoning the students to respond, and certainly not to respond in a certain manner. While the teacher acts indirectly in this way, where the 'weak' feelings appear as an intermediary, he may indirectly summon the students to take responsibility. However, the "weak" teacher does not demand any response from the students, nor does he give any specific directions on how to respond. The teacher thus avoids coercion.

Furthermore, the teacher is being indirect in more than one way. His indirectness works partly through the acknowledgement of his own inadequacy, a kind of self-sacrifice, and partly through caring strongly about Else, in which her grief and pain are communicated through the teacher. He has in a Levinasian perspective taken responsibility for Else. The teacher may therefore appear as a reflection in which the students can see that he is sorry that he has failed and also Else's pain. They can see Else's pain through a strong person-that is, the teacher who now shows 'weakness.'

This indirectness can further help the students to see themselves in relation to the entire bullying situation. The teacher's 'weakness' may thus have summoned the students in an indirect manner, where they may perceive themselves as participants in the bullying situation. In this way, the teacher has indirectly anchored the case of bullying in the students' position and existence so that they can be governed by their inner moral sense in regard to the existential decision they might make in relation to the bullying.

What is more certain than this is that the teacher's 'weak' and indirect action will likely avoid the risk that the students will be treated unjustly by adopting a language that may appear oppressive, prejudiced and stigmatising. If the students adopt 
anything from the teacher, it will likely be a mild language, which is unlikely to cause much harm if the attempt to stop the bullying should fail. The students' conscience will still have been activated but in a more indirect and a far milder way than through the unjustly shame Bjørndal subjected his students to. Instead of external reproaches and accusations, the teacher could use a more ethically legitimate and just approach to indirectly bring the students to a place where they can see and judge themselves in relation to what happened to Else.

Since Bjørndal's 'weakness' in this hypothetical attempt is about showing feelings, it is important to add that feelings must not be manipulated. Teachers must never think thus: "If I feel this, then I will be able to be indirect in this or that way." That is not my point at all. The point is rather about daring to show 'weakness,' and when you do, indirectness will work on its own. What I have tried to do in this hypothetical attempt is merely to display how indirectness might turn out as a result of showing certain 'weak' feelings.

\section{Note}

1 We do not know if this is really a method which is systematic and established. Most likely it is an approach used in this particular case. But since we do not know, I shall continue to use the word 'method' (and sometimes 'approach' and other notions where it seems most appropriate).

\section{References}

Barboza, G. E., Schiamberg, L. B., Oehmke, J., Korzeniewski, S. J., Post, L. A., \& Heraux, C. G. (2009). Individual characteristics and the multiple contexts of adolescent bullying: An ecological perspective. Journal of Youth and Adolescence, 38(1), 101-121.

Batsche, G. M., \& Knoff, H. M. (1994). Bullies and their victims: Understanding a pervasive problem in the schools. School Psychology Review, 23(2), 165-174.

Benner, D. (2012). Allgemeine Pädagogik. Eine systematisch-problemgeschichtliche Einführung in die Grundstruktur pädagogischen Denkens und Handelns [General pedagogy]. A systematik-problemoriented introduction in the foundational structures of pedagogical thinking and action. Weinheim: Juventa.

Biesta, G. (2014). The beautiful risk of education. Boulder, CO: Paradigm Publishers.

Bollnow, O. F. (1976). Eksistensfilosofi og pedagogikk [Existentialism and education]. Copenhagen \& Oslo: Christian Ejlers' forlag.

Bradshaw, C. P., Sawyer, A. L., \& O'Brennan, L. M. (2007). Bullying and peer victimization at school: Perceptual differences between students and school staff. School Psychology Review, 36(3), 361-382.

Canty, J., Stubbe, M., Steers, D., \& Collings, S. (2016). The trouble with bullying: Deconstructing the conventional definition of bullying for a child-centred investigation into children's use of social media. Children \& Society, 30(1), 48-58.

Carrera, M.V., DePalma, R., \& Lameiras, M. (2011). Toward a more comprehensive understanding of bullying in school settings. Educational Psychology Review, 23(4), 479-499.

Corriveau, K. H., Min, G., Chin, J., \& Doan, S. (2016). Do as I do, not as I say: Actions speak louder than words in preschoolers learning from others. Journal of Experimental Child Psychology, 143(3), 179-187. 
Ellwood, C., \& Davies, B. (2010).Violence and the moral order in contemporary schooling: A discursive analysis. Qualitative Research in Psychology, 7(2), 85-98.

Eriksen, I. M. (2018). The power of the word: Students' and school staff's use of the established bullying definition. Educational Research, 60(2), 157-170.

Espelage, D. L. (2014). Ecological theory: Preventing youth bullying, aggression, and victimization. Theory Into Practice, 53(4), 257-264.

Espelage, D. L., \& Swearer, S. M. (Eds.) (2004). Bullying in American schools: A social-ecological perspective on prevention and intervention. New Jersey: Lawrence Erlbaum.

Espelage, D. L., \& Swearer, S. M. (Eds.) (2011). Bullying in North American schools. New York \& London: Routledge.

Frånberg, G.-M., \& Wrethander, M. (2011). Mobbning - en social konstruktion? [Bullying - a social construction?] Lund: Studentlitteratur.

Hansen, H. R. (2014). Sanctions against bullying and disruption in school. In R. M. Schott \& D. M. Søndergaard (Eds.), School bullying: New theories in context (pp. 241-266). Cambridge: Cambridge University Press.

Hein, N. (2017). New perspectives on the positioning of parents in children's bullying at school. British Journal of Sociology of Education, 38(8), 1125-1138.

Hektner, J. M., \& Swenson, C.A. (2012). Links from teacher belief to peer victimization and bystander intervention tests of mediating processes. Journal of Early Adolescence, 31, 93 105. doi: $10.1177 / 0272431611402502$.

Hong, J. S., \& Espelage, D. L. (2012). A review of research on bullying and peer victimization in school: An ecological system analysis. Aggression and Violent Behavior, 17(4), 311-322.

Kallestad,J. H., \& Olweus, D. (2003). Predicting teachers' and schools' implementation of the Olweus bullying prevention program: A multilevel study. Prevention \& Treatment, 6(1), Article 21. https://doi.org/10.1037/1522-3736.6.1.621a

Kemmis, S. (2012). Researching educational praxis: Spectator and participant perspectives. British Educational Research Journal, 38(6), 885-905.

Klafki, W. (2001). Dannelsesteori og didaktik - Nye Studier [Theory of Bildung and didactics - new studies]. Århus: Klim.

Koerrenz, R. (2017). Existentialism and education: An introduction to Otto Friedrich Bollnow. Berlin: Springer.

Kousholt, K., \& Fisker, T. B. (2015). Approaches to reduce bullying in schools: A critical analysis from the viewpoint of first- and second-order perspectives on bullying. Children E Society, 29(6), 593-603.

Levinas, E. (2003). Totality and infinity: An essay on exteriority (A. Lingis, Trans.). Pittsburgh, Pennsylvania: Duquesne University Press.

Levinas, E. (2009). Otherwise than being: Or beyond essence (A. Lingis, Trans.). Dordrecht: Kluwer.

Neher, W. (2020). Communicating ethically. Character, duties, consequences, and relationships. New York \& London: Routledge.

Olweus, D. (1993). Bullying at school. Malden, MA: Blackwell.

Report to the Storting (white paper), no. 22 (2010-2011). Motivation-Mastery - Possibilities. Oslo: Ministry of Education.

Ringrose, J., \& Renold, E. (2010). Normative cruelties and gender deviants: The performative effects of bully discourses for girls and boys in school. British Educational Research Journal, 36(4), 573-596.

Roberts-Cady, S. E. (2009) Rethinking justice with Levinas. In D. Manderson (Ed.), Essays on Levinas and Law. Palgrave Macmillan, London. https://doi.org/10.1057/ 9780230234734_14 
Roland, E., \& Galloway, D. (2002). Classroom influences on bullying. Educational Research, 44(3), 299-312.

Roland, E., \& Galloway, D. (2004). Professional cultures in schools with high and low rates of bullying. School Effectiveness and School Improvement, 15(3-4), 241-260.

Rossiter, A. (2011). Unsettled social work: The challenge of Levinas's ethics. The British Journal of Social Work, 41(5), 980-995.

Rousseau, J.-J. (2003). Émile (B. Foxley, Trans.). London: Everyman.

Saeverot, H. (2015). Revitalising Bildsamkeit? Studies in Philosophy and Education, 35(1), $1-16$.

Schott, R. M. (2014). The social concept of bullying: Philosophical reflections on definitions. In R. M. Schott, \& D. M. Søndergaard (Eds.), School bullying: New theories in context (pp. 21-46). Cambridge: Cambridge University Press.

The Education Act (2016). Act relating to primary and secondary education and training. Available at: https://lovdata.no/dokument/NLE/lov/1998-07-17-61 (accessed 21 November 2019)

Thomassen, M. (2016). "Vi er tre når vi er to.” Ansvar og rettferdighet i Emmanuel Levinas' filosofi ["We are three when we are two." Responsibility and justice in the philosophy of Emmanuel Levinas]. Fontene forskning, 9(2), 68-79.

Thornberg, R., Baraldsnes, D., \& Saeverot, H. (2018). In search of a pedagogical perspective on school bullying. Nordic Studies in Education, 38(4), 289-301.

van Hek, M., Kraaykamp, G., \& Pelzer, B. (2018) Do schools affect girls' and boys' reading performance differently? A multilevel study on the gendered effects of school resources and school practices. School Effectiveness and School Improvement, 29(1), 1-21. DOI: 10.1080/09243453.2017.1382540

VanZoeren, S., \& Weisz, A. N. (2018). Teachers' perceived likelihood of intervening in bullying situations: Individual characteristics and institutional environments. Journal of School Violence, 17(2), 258-269. doi:10.1080/15388220.2017.1315307.

Veenstra, R., Lindenberg, S., Huitsing, G., Sainio, M., \& Salmivalli, C. (2014). The role of teachers in bullying: The relation between antibullying attitudes, efficacy, and efforts to reduce bullying. Journal of Educational Psychology, 106(4), 1135 - 1143. http://dx.doi. org/10.1037/a0036110.

Volk, A. A., Dane, A.V., \& Marini, Z. A. (2014). What is bullying? A theoretical redefinition. Developmental Review, 34(4), 327-353.

Yoon, J., \& Bauman, S. (2014). Teachers: A critical but overlooked component of bullying prevention and intervention. Theory Into Practice, 53(4), 308-314. doi:10.1080/00405841 .2014 .947226 .

Yoon, J., \& Kerber, K. (2003). Bullying: Elementary teachers' attitudes and intervention strategies. Research in Education, 69(1), 27-35.

Yoon, J., Sulkowski, M., \& Bauman, S. (2016). Teachers' responses to bullying incidents: Effects of teacher characteristics and contexts. Journal of School Violence, 15(1), 91-113. doi :10.1080/15388220.2014.963592.

Zych, I., Farrington, D. P., \& Ttofi, M. M. (2018). Protective factors against bullying and cyberbullying: A systematic review of meta-analyses. Aggression and Violent Behavior, 45, 4-19. doi:10.1016/j.avb.2018.06.008 


\section{Time}

\section{How may 'genuine time' be an integral element in a student's existence? A case study}

\section{Introduction}

Time, which is the theme of this chapter, is a very complicated concept for many to grasp or explain as a lived experience. To discuss time as one time is not possible. There are many different types or forms of time that often stand in relationship to each other, from our everyday perception of time to biological time as embodied, to a quantum mechanical perspective of time that is abstract and in some applications highly theoretical. Even though there is more than one time, our everyday lives are often ruled by so-called clock time- that is, mechanistic and chronological time. By using a clock, time can be followed by its divisions: hours, minutes and seconds. Both day and night are ordered chronologically: 1 to 12, representing a.m. and then from 13 to 24 , representing p.m. In a contemporary sense, this is only one way to order time, it is in many ways necessary to make and keep appointments, as we need to know when we are going to school, to work, to the doctor, and all the ever-day-ness associated in life (Rovelli, 2018). Still, clock time is not really time (Bergson, 1990); rather, it is a human-made device that shows "time" as a way to gain control of everyday life (Morgan, 2019; Saeverot, 2013).

Similarly, the calendar is a tool for understanding and controlling seasonality throughout the world. Such organisation became a natural part of the Roman Empire's rule of the Roman Empire. In fact, it was the Roman Emperor Julius Caesar who introduced the calendar to the Western world, the so-called Julian calendar, in 46 BC. This calendar, like clock time, is formed chronologically. Thus Caesar could control the people and the society. The Julian calendar was used for over 1,600 years but was eventually adjusted, corrected and simplified by Pope Gregor XIII in 1582. This was the so-called Gregorian calendar, which is also formed chronologically, from January to February to March, and so on. The Gregorian calendar is still being used in many parts of the world. Hence, we are more strongly influenced by the Roman's time orientation than we might think. In any case, the basic ideas of the Julian calendar are still applicable and spread throughout much of the world. Thus, this chronological categorisation, and order of time, characterise much of society's perception of time.

Such understanding of time has been part of the so-called neoliberal education. Neoliberalism emerged as a political idea in the 1930s, challenging both American 
capitalist liberalism and communist-based economy (Strobelt, 2018). In recent times, the term has resurfaced with a different meaning, referring to market liberalism. This has had major consequences for schools, education policies and curricula in the Western world, which are increasingly organised and operated according to market economy principles (ibid.). The neoliberal influence in schools and teacher training is evident by an increasing focus on directness, testing and education programmes which are based on management by objectives (Torgersen, 2015) within a prescribed time frame to meet academically imposed standards. The goals of education then, which are subject to a calculated and chronological idea of time, steer the teaching not pedagogically by the teacher, but by governments to control the daily operations in the classroom - which are turning more and more into direct methods.

\section{Dewey, time and interaction}

Although John Dewey does not offer a direct critique of neoliberal education, we can use his theory of time as an indirect critique of neoliberal education and its imposed mechanistic concept of time. In particular, I turn to Time and Individuality (1940/1998), in which Dewey discusses problems that may arise when time is perceived as homogeneous and chronological, similar to the clock or calendar arrangement discussed above. According to Dewey (1998, p. 219), such an understanding of time leads to a problem when viewed in light of education that has a purpose to individualise and free the students. The chronological structure of the homogenous time forces us to perceive reality in a predetermined manner, often by expanding something in a particular order. We end up with a mechanical structure, which lacks prerequisites for freedom. The reason being that the individual will be trapped in a pattern characterised by routines and habits. Dewey, on the other hand, makes a case for "genuine time," which is connected to individuality and freedom. Dewey states,

Genuine time, if it exists as anything else except the measure of motions in space, is all one with the existence of individuals as individuals, with the creative, with the occurrence of unpredictable novelties. Everything that can be said contrary to this conclusion is but a reminder that an individual may lose his individuality, for individuals become imprisoned in routine and fall to the level of mechanisms. Genuine time then ceases to be an integral element in their being. Our behaviour becomes predictable because it is but an external rearrangement of what went before.

(Dewey, 1998, p. 225)

Genuine time is connected to contingency, novelty, and unpredictability, opposing the neoliberal's chronological conception of time. According to Dewey, it is the contingent and unpredictable that individualises us as humans: "Individuality conceived as a temporal development involves uncertainty, indeterminacy, or contingency. Individuality is the source of whatever is unpredictable in the world" (ibid., p. 224). 
Instead of being guided by conventions, habits and routines, Dewey wants to provide room for artistic creation and artistic activities - that is, abilities connected with individuality. To achieve this through educational processes, a contingent concept of time is required, first and foremost because such a concept of time will open the future, rather than blocking it by way of predetermination. Dewey offers the following:

To regiment artists, to make them servants of some particular cause does violence to the very springs of artistic creation, but it does more than that. It betrays the very cause of a better future it would serve, for in its subjection of the individuality of the artist it annihilates the source of that which is genuinely new.

(Ibid., p. 226)

Dewey argues for a concept of time that can create space for that which is genuinely new, including unforeseen events, which in turn can make room for individuality where each individual can stand forth as creative and original, both in thought and action. As a concrete example, Dewey points to Abraham Lincoln and how "genuine time" shaped him into a distinctive and individual person, quite different from everyone else (ibid., p. 224).

In other works by Dewey, specifically Democracy and Education (1916/1966), individuality is an advantage for the education of each and every individual. And it also functions as an opening for unreserved interaction with others-in a common development and learning process, while the actions occur and the experiences are being built up. Not least for Dewey (1966), interaction, based on communication, was the foundation of his criticism of an individual-oriented philosophy; or Cartesian subjectivity (Cogito, ergo sum/ I think, therefore I am; see Biesta, 2006, p. 36). Henceforth, I will, therefore, like Dewey (1966), connect both individuality and interaction in the practice of education.

While Dewey emphasises the art of teaching the students to be free and unique individuals, schools which are influenced by neoliberalism are characterised by instrumental and mechanistic thinking, efficiency and quantifiable results, such as national and international tests. Behind the neoliberal ideology, we find a chronological and mechanistic conception of time. As educators create space for both individuality and interaction, they create space for a form of freedom which is concerned with both individuality and interaction with others. Such freedom also requires certain forms of teaching, which will be elaborated on in the following sections.

\section{Description of the observation 'object' and a typical school situation}

In the extension of this perspective of freedom, I wish to concretise and contextualise Dewey's theoretised thoughts about time, with direct relation to current educational practice. Therefore, in the following, I will present key extracts from a case study of "John," a ninth-grade student. The purpose of the case is to clarify what the 
meaning of the concept of time, based on Dewey's understanding, can have for practical teaching today. Will the teaching demand direct and/or indirect approaches? The case "John" is thus used in two ways. Firstly, as a starting point for the analysis, with the aim of clarifying my theoretical findings, related to the meaning of time in teaching. Secondly, as an educational 'tool,' which hopefully has tangible value in the demanding everyday life of practicing teachers and educators.

John is not the student type on which the typical state curriculum in primary and secondary education and training is based - that is, a streamlined and learningwilling student. John is rather a reluctant student who opposes most of the school's academic tasks. As a backdrop to my main question-how is it possible to meet John in such a way that "genuine time" becomes an integral element in his beingI wish to provide a description of John and how he behaves in a typical school situation, and not the least how he is met by his teacher and teacher assistant.

John is a weak student academically, and his results (aka scores) in the vast majority of the school subjects are low when compared to students within a set metric. There is no particular difference in the theoretical and practical subjects in this way, and he shows little noticeable interest in anything but computer games. The only visible ambition John expresses during the observed school hours is the ever-repeated effort of perfecting his skills to make the least out of a school day. Any situation where he risks learning, he turns away, something he seems to be quite good at. In some subjects, John is provided academic supports, a special education programme where he is in a group of other academically challenged students. But here, too, he manages to hide from the learning and escape the tasks prescribed by the teacher.

\section{A day in the life of John}

How does a typical school hour look like for John? As the hour begins, John is one of the last of the students to find his place in the classroom. The teacher initiates the teaching by introducing and elaborating on the theme of the school hour. When the time has come for the students to conduct their tasks, John utters that he has not received any information of what he is supposed to do. However, he does not express this before the teacher has discovered that he is not doing anything related to the lesson. The teacher approaches John to describe the contents of the assignment. After the direct explanation, the teacher walks away from John and resumes class-wide attention to the rest of the youth.

John, on his part, clearly demonstrates that he is not bothering to read the text that is connected to the assignment. As explained by the teacher, he will require other materials, in the form of books or classroom resources, in order to perform the assignment. However, John spends a very long time trying to find this supplemental material. In addition, the task requires a specific format, assignment information is to be filled out in certain ways, but again, he spends a very long time on what he says, "I am thinking what to do." However, it is often difficult to perceive the results of this 'thinking process.'

One reason for that is that he often wanders around the classroom, while, for example, searching in his rather chaotic shelf, before emptying his school bag with 
all its contents on the floor, whereas disturbing his classmates on his way back to his seat. At best, he finds some of what he needs, but often he does not do anything useful. Either way, he is often found seated without doing what he is supposed to do. In fact, he seems quite happy doing nothing, while chatting to one of his classmates, who consequently is distracted from doing their own assignment.

Eventually, the teacher discovers that John is not doing what is expected academically. The teacher then walks over to John. Most often, the teacher struggles to gain John's attention. In one case, a train passes by the school. Instead of talking to the teacher, John prefers to count the train wagons. The teacher, on his part, really makes an effort to draw John's attention away from the train, when at long last, they can concentrate on the task.

Whenever the tasks contain written information, the teacher must read this out loud, as John himself does not make an effort to read. And as soon as the turmoil increases in the classroom, John gets very excited and pays all his attention to these upheavals. John never raises his hand to ask for something, nor does he ever contribute verbally in the classroom in any way. He only answers direct inquiries from the teacher, often in a mumbling fashion and with obvious discomfort. As such, the school hours continue, until it is time to finish and clear the desk before the end of the hour. In these moments he is both very fast and efficient, usually being the first student to leave the classroom.

\section{How was John met by the teacher and the teacher's assistant?}

One of the reasons for all this is, in my view, the neoliberal education's tendency to standardise, meaning that all students are supposed to achieve the same goals within a set standardised time. Such standardisation calls for teacher-driven instructions and third-person perspectives; in other words, explicit and direct approaches. As a result, John academically isolates himself, creating an ego existence in which 'genuine time' is blocked. Hence, the individuality that Dewey (1998) is talking about is suppressed. Due to this isolation, there is also no interaction with either the teacher or his fellow students, unless in disruption. The school has made many attempts to break John from this dysfunctional learning pattern, but so far, the professionals have not succeeded. Regardless, it is important to note how the teacher, and the teacher's assistant (TA), meet John on his terms within the class time.

At one particular time, in the classroom, John sat by his personal computer. He was supposed to work with a photo-editing task of his own photographs. The assignment, which was first communicated in writing and then orally for the whole class, was to be filled with personal content, and each of the students had to take responsibility for their own progression. Overall, the rather direct and explicit task implied self-motivating and well-functioning students. Not least, the task was arranged for those students who could easily submit to certain frameworks, including direct guidelines and defined patterns that pointed directly to predetermined solutions and correct answers.

One problem with such directness in education is that it does not make room for what Dewey categorises as 'genuine time,' neither for John nor the other 
students in the class. Due to these circumstances, the possibilities for providing a good experience for John were almost nonexistent. Nothing in the direct assignments is concerned about his inadequate skills. As for John, he spent his time in a typical fashion, apparently working on the PC. But his real activity was to shoot down enemies in a war game he had found online.

Since the teacher had his hands full with a rather large group of students, it took some time before he discovered this game diversion. When he eventually observed John's diversion, he shouted out in pure irritation, "Start working and do what you're supposed to do!" From my vantage point, I determine the teacher by way of this direct command seems to be influenced by a neoliberal language, in which all the students are brought into a pattern controlled by the mechanistic clock time. This commanding call did not make the task either more understandable or more tempting for John. One reason being that there was no unpredictability, for this was predictable for many frustrated teachers. The teacher's admonition in which genuine time could come to life for John, but this outburst does not act as an incentive for further engagement on John's part.

Such absence of unpredictability in an educational situation will, according to Dewey (1998, p. 225), hinder students from acting independently, which in turn will suppress the individual's individuality. John, on his part, continued his war game on the computer, which he actually did understand on a gaming-interest level. Through direct pedagogy, where time is chronologically ordered similar to the time of a clock (Saeverot, 2013), the teacher had attempted to awaken his student, who not only avoided doing what he was expected to do but even did something the students were not allowed to do. Perhaps this competitive interest in spending time playing games versus doing academics, along with the fact that the teacher's directive lacked clarifying information and was steeped in frustration, contributed to the reasons why a hopeless situation did not change.

In time, the TA tried to indirectly lure John into activity by offering herself as a model for his task, with the ugliest grimaces she managed to make. Through a kind of humour, she tried to draw him out of his state of learning resistance and at the same time "make him" interested in the assignment. The humour was surprising in its form of a more indirect approach, as opposed to the teacher's direct approach. The advantage of indirect pedagogy is that it can give life to certain aspects that characterise 'genuine time,' as offered by Dewey (1998), be it surprise, unpredictability or contingency. Regardless, the TA's rather unorthodox approach at best created a slightly better mood. The TA's form of indirect pedagogy by way of humour also lacked a thoughtful, thorough, and pedagogical plan. The humour was more an impulsive act, here and now, and all the TA seemed to achieve was that time went by for John. In short, the TA created a diversion to distract John from the gaming world, but in the end, John was not any more focused or productive academically.

For John, it was more tempting to shoot enemies than to be "seduced" by the TA's enticing attempt to get him out of his chair so as to find a photo camera. John now had total control of how much time was left of the school hour and argued very well that he did not have time to do anything before the end of the hour. John managed to maintain this discussion for so long that his point turned out to be 
right - he ran out of time. From a neoliberal stance, his learning shift was over. Clearly annoyed, the teacher replied explicitly that he at least had to make sure he had a photo to work with for the next time. Then the school bell was ringing and the reluctant student left the classroom. The teacher's realisation was it was going to be an entire week until the next one-hour session would be dedicated to this particular task. It is quite obvious that such a lack of continuity in the work did not give much hope of John finishing the assigned task.

\section{How may 'genuine time' become an integral element in John's being?}

In the previous section, we have seen that the teacher, along with the TA, tried many ways to penetrate John's academic learning defences. The teacher was direct in his approaches, and he has spent time talking to John face-to-face, while the TA used indirect approaches; nothing succeeded. Certainly, there is no formula for struggling students like John, whose individuality and interaction with others are suppressed. So, if the teacher really wants to make a difference in John's life, he must find ways of breaking up the routines that govern John's way of life and, not least, create spaces so that 'genuine time' can become an integral element in John's being. And this is not a simple task in the highly-regulated classrooms of today. When such time becomes part of being, the individual's individuality can come to life, which in turn can lead to interaction with others. Said differently, 'genuine time' connects the individual to life itself, in which freedom can unfold. All this will require risk, both from the teacher and the student (see Biesta, 2014). Not least, there should be room for 'genuine time,' both in addition to, and in combination with, the learning goals, which in themselves are based on the chronological principles of the so-called clock time.

Now, to teach in such a way that 'genuine time' may become an integral element in John's life is a highly demanding matter. The teacher cannot go halfway into the situation; rather, an unreserved effort will be required from the teacher who may risk failing (Bollnow, 1959; Koerrenz, 2017). For example, the teacher may risk losing his authority, as well as his belief in his own ability to help and support others. The whole thing may even make the teacher discouraged in relation to other, similar situations (ibid.). Nonetheless, the teacher has no other choice than to spend all his effort on this situation, sacrificing time spent with the other children in the class; hence, the teacher is outnumbered in the neoliberal classroom.

Furthermore, the teacher must be able to seize the (coming) time or the 'moment' (Saeverot \& Torgersen, 2015) — that is, every possible thing that resists the typical defence of John. Essentially, he is to take advantage of the productive moment, grasp the situation and use the moment, finding solutions "here and now" without being guided by the school hour's defined learning goals. This is very demanding because such moments cannot be predicted, and the reason being that 'genuine time' can never be foreseen or calculated, as opposed to clock time.

This must take its (metric) time. It is important that it is the process that controls the duration, neither clock time nor any other instrumental idea (including 
predefined goals). In this process, where 'genuine time' comes into practice, unforeseen situations will and must be grasped. The unexpected arises as a result of a free interaction between the teacher and the student, without any external correctives or guiding frameworks. The teacher (as organiser) plays an important role in this process; that is, the teacher must make sure that surprising and seemingly unimportant words and opinions of the student are actually grasped and followed up. In practice, this represents the unforeseen. However, the teacher's follow-up or response, should not be subject to specific goals but rather function as assistance in such a way that statements and actions are elaborated on and possibly corrected by the student himself.

Indirect pedagogy can be of help in this situation (Saeverot, 2013, 2019). For example, the teacher may ask questions as a way of responding to the student. Another indirect strategy may be to mirror the statements, repeat what the student says, to force the student to reflect and articulate how his statements and opinions should be understood. In situations where chronological time functions as a framework for the interaction between teacher and student, such educative processes will not occur.

The unforeseen represents an unopened source of education, ready to be 'uncovered' and used, here and now, in the moment. When the unforeseen is brought into education in this way, we are dealing with a non-chronological and coming time perspective (Saeverot \& Torgersen, 2015). The ongoing-based situation will then steer the teacher's choices and actions, which are focused on the 'present,' with less attention to the predetermined learning goals. The emerging situation will contain a lot of information, which will thus serve as the basis for the teacher's reflections and actions. But to detect this information diversity that appears in the present, the teacher must make every effort to identify and process this in an open and unreserved manner. By no means should the teacher ignore the unforeseen; rather, he must actively work to ensure that the unforeseen can come to light and unfold as graspable information (Torgersen \& Saeverot, 2015).

The point is not to replace the typical structure and chronology of teaching with the unforeseen. It is rather a matter of breaking up a one-sided pattern in the state and politically controlled education, which in many ways are far away from Dewey's thoughts on 'genuine time' and individuality. State-controlled education, which is influenced by neoliberalism, thinks that school education is not good enough and therefore needs constant quality control by way of national and international tests and rankings. A consequence of that is that many schools and teacher education programmes in the Western world focus too little on indirectness, which is an essential characteristic of education for the unforeseen (Saeverot \& Torgersen, 2015). Instead, schools and teacher education programmes are based on management by objectives (ibid.), often part of neoliberal agendas to directly control education systems.

This is exactly what Dewey (1998, p. 226) warns us against—namely, that teaching turns into routines and mechanical patterns, predictable and controllable by external authorities, most often at the expense of a teacher's time and the pedagogical possibilities that would emerge as a natural part of the day. Nevertheless, the 
focus on learning goals, which have the order of clock time, can be combined with the unforeseen, whose foundation is formed by 'genuine time.' Such a combination does require that the teacher seizes both direct and indirect signals and hints from the students, here and now, while using this as the basis for pedagogical choices, communication and practical facilitations.

However, interaction requires active involvement from all parties, not just from the teacher's side. John must also be open for something to happen, and he must, independently, choose to accept the teacher's gift. But as many know, not all students wish or are ready to receive the teacher's gifts. So, it is certainly not a small task that the teacher must try to accomplish. What's at risk is that the student will, perhaps in a disrespectful manner, say no to his gift. But this must not stop the teacher from making new attempts that can create space for 'genuine time,' in which John can let go of his defence and be open for the gift. The teacher cannot simply wait passively for John to open up. The teacher's task is to work actively for certain moments to occur so that 'genuine time' can be part of the life of John. However, such moments always happen surprisingly, if at all. Thus the teacher must constantly seek new approaches, perhaps searching for interests that can touch John and then use these interests as means in order to come closer to John's world (see also Werler, 2015). By seductively inciting John's curiosity, going beyond traditional teaching methods, the teacher can "deceive" John to open up before he starts resisting (cf. Chapter 3). This is an indirect approach, a backdoor, and with luck, it may sow a tiny seed of curiosity and interest on John's behalf (see Saeverot, 2019).

But to receive the teacher's gift is far from a simple matter seen from the perspective of the reluctant student struggling academically. Such a reception will probably be very demanding for John, who faces a risk where his world ends in disaster. But like the teacher, John cannot go halfway into the situation, even though success is never a guarantee in matters like these. As the situation looks now, he seems pretty sure he will not succeed. We can therefore assume that he has chosen a safer way of existing where it is, for him, easier and more comfortable not trying. It may be easier to live with the world conception and self-deception he leans on, than risking to choose a new worldview where individuality and interaction are involved - that is, a worldview which not only requires a lot of effort but also requires that he lets go of his safe and highly controlled way of existing in the world. It is, therefore, possible that John, unlike the teacher, has no desire to change the situation. For his way of existing in the world works perfectly well from his perspective. In such a background, it is quite likely that John says no to the teacher's gift, after which the teacher may be forced to make use of drastic means in his teaching. For example, the teacher may try to draw John away from his escaping from both himself and the world by way of unexpected disruptions and interferences, which do not allow John to continue to exist in an almost undisturbed and self-imposed drowsiness (see Saeverot, 2013, 2019). If, however, John still does not want to receive the teacher's gift, there is nothing the teacher can do about it other than trying again, with new perspectives and strategies.

There is a lot at stake here, not only in relation to the teacher's professional development but also in relation to the pedagogical through interpersonal relationships and 
interaction. In addition to teaching in such a way so as to create space for 'genuine time' and individuality, teachers also need to strive for a democratic and social aspect, just as Dewey (1966) assumes. Furthermore, teachers must be aware that their communication and requests must not be perceived by the students as a personal and superficial act.And they must invite trust and involvement during the communication (Torgersen \& Saeverot, 2015). There are two perspectives involved in this process, as I explained in the introduction. Firstly, the realisation of individuality is good for each and every student. Secondly, the realisation of individuality is good for the others (the class, the students, the teacher and the community). Teachers should therefore strive to make the students understand their important role in the community and that they do have a place in the world, which is the prerequisite for interaction.

\section{Conclusion}

If John never experiences a life-changing meeting, both he and the teacher will fail (Bollnow, 1959). The teacher may experience this as a personal loss, while John may be eternally and existentially injured. Both parties risk losing, but they may also gain something in the form of freedom, such as individuality and interaction, and that is why such a risk can be regarded as 'beautiful' (see Biesta, 2014). What I have tried to highlight is that it is important that teachers, in their lesson planning, place less emphasis on management by objectives. Such emphasis is based on a chronological and highly predicted understanding of time, which in turn is calling for direct approaches. In addition, they should plan to teach in such a manner that it is possible to exploit unforeseen events in teaching situations. This calls for indirect approaches in which 'genuine time' can become an integral element in the students' being.

Utilising unpredictable moments and situations should be perceived as part of the natural interaction processes in the classroom and should be more emphasised in the planning of teaching. This, however, requires a pervasive reorganisation of the school day for both teachers and students. For example, a lesson must not necessarily be guided by clock time. This requires a political governance of the school and education sector, which is based on education as a discipline, instead of the neoliberal control and management regime. This will in turn make room for indirectness and genuine time, which goes hand in hand with the unforeseen, having no cause, but may itself be the cause of something else (for example, an experience or an insight). The neoliberal education, on the other hand, presupposes the foreseen, making it virtually impossible to create space for freedom, unique individuality and novelty. Thus the seemingly unfeasible task: How to make room for freedom, novelty and innovation in school when the boat is moored both in the front and back (Løvlie, 2015, p. 269).

\section{References}

Bergson, H. (1990). Time and free will: An essay on the immediate data of consciousness (F. L. Pogson, Trans.). Montana: Kessinger.

Biesta, G. (2006). Beyond learning. Democratic education for a human future. Boulder, CO: Paradigm Publishers. 
Biesta, G. (2014). The beautiful risk of education. Boulder, CO: Paradigm Publishers.

Bollnow, O. F. (1959). Existenzphilosophie und Pädagogik [Existential philosophy and pedagogy]. Stuttgart: Kohlhammer.

Dewey, J., 1966. Democracy and education. New York: Free Press.

Dewey, J. (1998). Time and individuality. In L. A. Hickman \& T. M. Alexander (Eds.), The essential Dewey, volume 1. Pragmatism, education, democracy (pp. 217-227). Bloomington, Indianapolis: Indiana University Press.

Koerrenz, R. (2017). Existentialism and education: An introduction to Otto Friedrich Bollnow. Berlin: Springer.

Løvlie, L. (2015). Det uforutsettes pedagogikk [The pedagogy of the unforeseen]. In G.-E. Torgersen (Ed.), Pedagogikk for det uforutsette [Pedagogy for the unforeseen] (pp. 267-272). Bergen: Fagbokforlaget.

Morgan, M. L. (Ed.) (2019). The Oxford handbook of Levinas. Oxford: Oxford University Press.

Rovelli, C., 2018. The order of time. New York: Riverhead Books.

Saeverot, H. (2013). Indirect pedagogy. Some lessons in existential education. Berlin: Springer.

Saeverot, H. (2019). Indirect teaching. In J. Baldacchino, K. Freedman \& R. Hickman (Eds.), International encyclopedia of art and design education, Volume 3 (pp. 1-13). Hoboken, NJ: John Wiley \& Sons.

Saeverot, H., \& Torgersen, G.-E. (2015). Tid, kunnskap og didaktikk i lys av det uforutsette [Time, knowledge and didactics in light of the unforeseen]. In G.-E. Torgersen (Ed.), Pedagogikk for det uforutsette [Pedagogy for the unforeseen] (pp. 310-317). Bergen: Fagbokforlaget.

Strobelt, M. (2018). Kritisk pedagogikk - svar på dagens kunstpedagogiske utfordringer? [Critical pedagogy -An answer to today's challenges in art education?] Journal for Research in Art and Sports Education, 2(2), 5-19.

Torgersen, G.-E. (Ed.) (2015). Pedagogikk for det uforutsette [Pedagogy for the unforeseen]. Bergen: Fagbokforlaget.

Torgersen, G.-E., \& Saeverot, H. (2015). Strategisk didaktisk modell for det uforutsette [Strategic didactic model for the unforeseen]. In G.-E. Torgersen (Ed.), Pedagogikk for det uforutsette [Pedagogy for the unforeseen] (pp. 317-339). Bergen: Fagbokforlaget.

Werler, T., 2015. Refleksiv improvisasjon. Undervisning og det uforutsette [Reflective improvisation. Teaching and the unforeseen]. In G.-E. Torgersen (Ed.), Pedagogikk for det uforutsette [Pedagogy for the unforeseen] (pp. 283-296). Bergen: Fagbokforlaget. 


\section{Education research \\ The direct and indirect paths of education research}

\section{Introduction}

This chapter shows that educational research can take both direct and indirect paths. With a direct path, I mean that educational practice is examined directly through the discipline education, and with an indirect path, I mean that educational practice is examined indirectly through non-educational disciplines. What I shall discuss in this chapter are the positive and negative consequences of being direct and indirect in educational research. For example, indirect approaches can develop knowledge that is not really relevant to education, and in the worst case, as we shall see next, education as an academic discipline can be deprived of its autonomy and independence. On the other hand, indirect routes in educational research can be utiliDsed to the advantage of the academic discipline of education, in the way that specific educational knowledge and theory are developed.Therefore I ask: when is it most appropriate to be direct, when is it most appropriate to be indirect and when is it most appropriate to combine directness and indirectness in educational research? The question is based on the purpose of developing educational theory, as well as strengthening education as an autonomous discipline.

In order to address this question in more detail, I would like to begin by accentuating that modern education has to a large degree evolved into an inter-discipline in the form of educational sciences (henceforth: ESS; see Table 6.1 for a definition of ESS) where multiple disciplines are involved in educational research (Bellmann, 2017; Saeverot \& Kvam, 2019). Thus, the research object, e.g. educational practice (henceforth: EP; see Table 6.1 for a definition of EP), is not examined directly from the point of view of education. Rather, knowledge or theory stemming from EP is developed indirectly, through non-educational perspectives.

To think non-educationally about education is not only a trend in the AngloAmerican tradition of education but also within the Continental Pädagogik tradition (Säfström \& Saeverot, 2017). The German educationist Klaus Prange (2005, p. 15; my translation) clarifies this development:

When it comes to questions of learning, the psychologists have the word. When it comes to the content in public education (curriculum), the so-called 'subject didactics' make the decisions. Whenever questions of organisation and 
social connections of learning and education are debated, sociologically oriented experts come into play. As for the objectives and moral issues of education, Pädagogik turns to its origin; namely, philosophy and theology, if, that is, these issues are not politically determined.

Instead of asking educational questions in the first place, the researchers take a noneducational viewpoint, e.g. a psychological, sociological or philosophical point of view (Biesta, 2011). For sure, the Pädagogik tradition, as opposed to the AngloAmerican tradition of education, is associated with the Continental construction of education that does not adopt the inter-disciplinary approach to education but rather embraces a unique view of education as a discipline in its own right (Biesta, 2011; Säfström \& Saeverot, 2017). It is about thinking educationally about education (Saeverot \& Biesta, 2013). Instead of detouring through other disciplines, knowledge and theory are developed directly from the point of view of education. But as I pointed out, the tendency to abandon the idea of education as an independent discipline is evident in the Pädagogik tradition, as the history and development of Pädagogik in Germany and Scandinavia, and other European countries as well, show an enormous willingness on the part of research councils, policy forums, politicians, researchers and others to adhere to disciplines other than education (Bellmann, 2017).

Table 6.I Overview of the different areas of education

\begin{tabular}{ll}
\hline Educational Practice (EP) & Within EP, educators conduct an \\
education for the good of the person & and an education for the good of \\
humankind. & Within ESS, EP is examined indirectly \\
from multiple disciplines. & \\
Educational Sciences (ESS) & ET is an indirect operation, as non- \\
educational knowledge-which is & developed indirectly through ESS-is \\
translated into educational knowledge. & \\
ETK is a direct operation, as educational & and practice-based knowledge are \\
developed directly through EP. ETK is \\
motivated by the improvement of EP. \\
ETH is an indirect operation, as EP is \\
examined indirectly, through ETK. ETH \\
is motivated by questions of truth, \\
examining whether the practice-based \\
knowledge developed through ETK is \\
true. \\
SE is an overarching term which includes \\
all the above sub-areas of education. SE \\
is autonomous, meaning a self-governing \\
discipline, with the right to organise its \\
own activities and make independent \\
decisions.
\end{tabular}


However, this development of producing knowledge and theory indirectly, through non-educational disciplines, has its drawbacks (Säfström \& Saeverot, 2017). For example, we have seen that scholars consider education to be philosophical and that concrete and practical-educational questions must be interpreted from the fundamental principles of philosophy (cf. Prange, 2005; Skjervheim, 1995). When forced to go indirectly through philosophy in this way, education is easily reduced to applied philosophy. The same tendency is also obvious within the field of sociology of education, in which researchers easily take an indirect path by way of viewing EP from sociological objectives and interests, e.g. related to gender, equality, identity, socio-cultural developments and multiculturalism, to name but a few (Su \& Bellmann, 2018). Although these concepts and objectives may be relevant to education, the problem is that they are often formed and executed from a sociological perspective (ibid.). This is perhaps the main problem with education as an inter-discipline - namely, the willingness to be indirect by borrowing objectives, concepts, theories and methods from external sources.

Already in 1929, in The Sources of a Science of Education, John Dewey claimed, "Education is autonomous and should be free to determine its own ends, its own objectives" (Dewey, 1929, p. 38). According to Dewey, ends and objectives should be determined directly from within education, rather than being determined indirectly through other disciplines. The singular form of Dewey's term 'science of education' (henceforth: SE), as opposed to the plural term 'educational sciences' (ESS), underlines that for Dewey, education is autonomous, meaning a self-governing discipline, with the right to organise its own activities and make independent decisions. This definition is close to the etymological meaning of the concept of autonomy, which derives from the Greek autonomous (from autos 'self' and nomos 'law'), meaning having its own laws (Lexico, 2020). In light of this autonomous idea, Dewey $(1929$, p. 38) warned " $[\mathrm{t}]$ o goes outside the educational function and to borrow objectives from an external source" because that would be "to surrender the educational cause." In order not to surrender the educational cause, objectives must be developed directly from education.

However, advocating for education as a self-governing or an autonomous discipline is not the same as calling for it to be an isolated discipline. Education should and must collaborate with other disciplines but without being totally dependent on the premises of these other disciplines. Thus, there should be room to be indirect in terms of educational research. Let me take an example from modern physics to clarify this point. To find solutions to certain problems, philosophical perspectives may be indirectly included in the works of physics but not in such a manner that the findings of physics are subdued by philosophical principles. Philosophy, or any other discipline for that matter, is subject to the discipline of physics, not vice versa. Such a relationship is also found in other disciplines, such as medicine, where other disciplines-e.g. chemistry, physics, sociology and philosophy - are indirectly drawn into the research in order to provide new perspectives to medical questions. It is important to add that the discipline of medicine is not overruled by these other disciplines.

In my view, education could learn from autonomous disciplines such as physics and medicine, in the sense that sources from other disciplines can be used indirectly, 
but only after education has developed and clarified problems, aims and purposes directly, or from within education itself. The reason for this is that an educational view on education is the only way to generate educational knowledge (Biesta, 2011). Overall, EP, which in my view is basically about an education for the good of the person and an education for the good of humankind (following Kemmis, 2012; see also my elaboration on this in the introduction), should be examined directly from the point of view of education, plus indirect examinations through psychology, sociology, philosophy and other disciplines (Saeverot \& Biesta, 2013).

It is all a question of how educational research is organised; hence, I ask, How may educational research be organised to take advantage of its direct and indirect paths so as to produce educational theory and safeguard the autonomy of the discipline of education? In the following, I shall argue for a conceptual structure consisting of three interrelated perspectives: education as translation (henceforth: ETN), education as task (henceforth: ETK) and education as truth (henceforth: ETH).

Since I divide education into several areas, I will initially define these different areas in Table 6.1. More detailed definitions and explanations of these areas are offered in the text that follows.

As I will explain in more detail in the following sections, the relationships between these perspectives are both direct and indirect, and they are part of the overarching term the SE (see Table 6.1 for a definition of SE). Even though I am to a certain extent critical to an inter-disciplinary approach to education due to unnecessary indirectness, I also think there are some advantages with such a perspective and the fact that several disciplines are involved in educational research. A presupposition, though, is that ETN needs to get involved. My point is that education may not be independent of external sources; however, as I shall exemplify next, the findings from research from non-educational disciplines should, from an educational point of view, be translated into educationally relevant knowledge. In this way, there are two kinds of indirect paths to the development of theory. The first indirect route goes through non-educational disciplines which produces theory through EP. But in order for this theory to become educationally relevant, an additional indirect approach is required. What I mean is that the non-educational theory, which is the indirect means, must be translated through the area referred to as ETN. Thus, educational theory can be developed indirectly, first through noneducational disciplines and then through ETN (this is illustrated in Figure 6.1 at the end of this chapter).

Through ETK, EP is examined and reflected upon by those who are directly involved in this field, be it educators or educationists. The objective is to develop educational and practice-based knowledge. This is part of organising education as a strong, autonomous discipline, as the knowledge and theory developed comes directly from EP. With an educational viewpoint on EP, it is possible to develop unique educational knowledge and theory. Nonetheless, there is a need for an additional indirect approach in order to strengthen the educational theory developed through ETK. This indirect approach happens through ETH, where the practice-based knowledge can be further investigated and strengthened. Whereas ETK is motivated by the improvement of EP, ETH is motivated by questions of 
truth; however, not in the sense of universal truth (I will elaborate on that in the text that follows). A fundamental question which is addressed is thus: Can the practice-based knowledge developed through ETK be considered true? ETH thus has a direct interest in theory and an indirect interest in practice. Although the developed educational theory can in this way be considered to be strong, it still needs to be examined, from many different perspectives and preferably by several researchers. The research process described in this paragraph is illustrated in Figure 6.1 at the end of this chapter.

\section{Indirectness through ETN}

My following argument is not about replacing ESS with education as an autonomous discipline (SE). That would be an idealistic and, I believe, hopeless project. Besides, going indirectly through ESS may benefit SE. I, therefore, suggest that both ESS and SE can be given space to exist side by side while interacting with each other. If there is only room for ESS, we are, as Dewey (1929) warned against, in danger of surrendering the educational cause. Following this argument, there needs to be an opening for indirectness, in which ETN can translate non-educational knowledge into educationally relevant knowledge. If, on the other hand, there is no space for indirectness - that is, ETN-we face two dangers. Let me elaborate.

\section{Two things at stake}

As I implied in the introduction, modern views on education have more or less taken for granted that education is an inter-discipline rather than an autonomous discipline, as old and new inter-disciplinary variants of education have been regenerated and reestablished within the inter-discipline of ESS (Kristensen, 2017). For example, disciplines with no historical or direct connection to educational questions and problems, such as economics, political sciences, law and other disciplines, have been integrated into the structural framework of ESS (Wulf, 2003; Trippestad, Swennen, \& Werler, 2017). As for education, it is forced into the structure of this inter-discipline. Some may argue that this is not a problem at all or even claim that

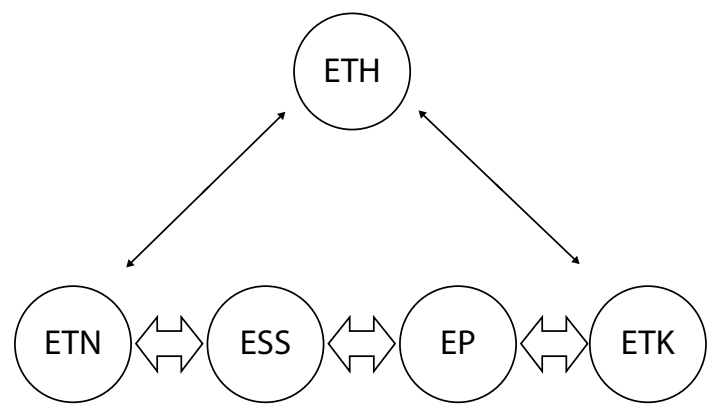

Figure 6.I The structure of SE. 
education should and must be an inter-discipline (Dale, 2005). Such an argument is generally grounded on a mindset based on the belief that the more perspectives on education the better (Trippestad et al., 2017). However, to organise education as an inter-discipline, and nothing else, will deprive (1) education of its autonomy, as well as (2) the space to develop distinctive educational knowledge.

These two problems emerge when multiple disciplines examine education; or, more specifically, the field of EP in order to develop knowledge. Such development of knowledge is rooted in the premises of non-educational disciplines. There is no direct line between an educational perspective and EP; hence, to think educationally about education is not an option. Thus, the inter-disciplinary structure of ESS makes it difficult, if not impossible, to secure the autonomy of education. As stated earlier, there may be benefits to including new and different perspectives into educational research, as one may gain a broad view of education. But there are also hazards. When education has been robbed of its autonomy by way of being subordinated to the inter-disciplinary field of ESS, the language of education becomes either completely absent or very unclear. The reason being that the disciplines examining EP do not generate distinctive educational knowledge, as the points of view are non-educational (Biesta, 2011). In other words, if the research object is studied from a non-educational perspective, and not directly from an educational point of view, the research object remains more or less unidentifiable with regard to the educational dimension (ibid.).

Let me offer a concrete example.Various fields, such as philosophy of education and sociology of education, strive to elucidate educational issues and problems from their particular viewpoints. The danger here is that education may fall apart and end up in a number of research areas, each with its own specific perspective. The direct path between education and EP, or the possibility to think educationally about education, is thus being obstructed. Moreover, in many cases, these different research areas of education have little or no direct contact with each other and sometimes also have little or no interest and understanding of each other's research (cf. Arcilla, 2002). We then face two unfortunate consequences. Firstly, the autonomy of education will suffer as it is governed and controlled indirectly by other disciplines. Secondly, one cannot develop educational knowledge by investigating EP only through the indirect lenses of philosophy, sociology, psychology, etc. To generate specific educational knowledge, researchers need to examine education directly from the viewpoint of education (Biesta, 2011). The point being that the research field associated with education also needs to include education as a perspective, as a first among the perspectives of other disciplines.

\section{ESS as an indirect source of knowledge for ETN}

However, to safeguard the autonomy of education while being able to generate educational knowledge, I shall argue that the so-called transfer problem (Biesta, Allan, \& Edwards, 2014) must be solved. The actual solution to the transfer problem can happen indirectly, but before I explain this, what signifies the transfer problem? First and foremost the transfer problem is a result of the multiple 
perspectives of education discussed previously; that is, it is connected to the challenge that knowledge generated from non-educational disciplines does not generate educational knowledge. In an educational light, such non-educational knowledge should therefore be transferred or translated into educational knowledge. This is the indirect solution to the problem. The following thought experiment from research on reading and writing difficulties can perhaps clarify what I mean by the transfer problem and how it can be solved by way of indirectness.

Will a linguist be able to contribute to the development of educational knowledge, or will the linguist add linguistic interests, such as increasing the competence of grammar, that might exacerbate reading and writing difficulties when we see this in relation to the interests of education? Might the linguist force linguistic interests such as grammar and semantics on the research so as to solve his or her own problems associated with reading and writing difficulties - problems that may not initially be associated with educational interests (e.g. the interest that students may find their place in the world as subjects (Biesta, 2014)) — with the result that the research is complicated and perhaps even driven away from educational perspectives?

How may the transfer problem be solved? How may educational research benefit from the knowledge generated from disciplines other than education? This is where educationists have a mediating role in which research from non-educational disciplines is translated into educational knowledge and possibly also into educational theory (Bellmann, 2017). Instead of going directly to EP, the educationists take an indirect route through their mediating role. The path goes via the linguistic knowledge produced from a practical situation and is then translated into educational knowledge or relevant knowledge for education. In this way, educationists can strengthen and legitimise the educational dimension in research, theory and practice.

Without the mediating role of education, it is not self-evident that inter-disciplinary educational research is directly related to education, on which particular research may ultimately appear to be more or less meaningless for the discipline of education. Without the indirect line between EP and ETN, through ESS, there is a danger that different types of research bring research and knowledge away from the educational dimensions. I, therefore, propose that ESS should be regarded as an indirect source of knowledge for SE. This implies that ETN examines and processes the knowledge that ESS have produced, and eventually translates this knowledge into educationally relevant knowledge. For example, ESS rely heavily on learning theories which have been developed in disciplines other than education, such as psychology (Dale, 2005). One of the consequences of this is that psychological questions - such as 'How does learning occur?' 'How do students learn?' are given priority over educational questions - such as 'How to teach for subjectification (in which each and every student may appear as someone rather than something)?' And, 'How do teachers teach for subjectification to occur?' (Biesta, 2014). Through indirectness, specifically translation, educationists ask what questions and understandings become possible when we see psychological questions in terms of educational questions (cf. Ruitenberg, 2009). 


\section{Directness through ETK}

So far, I have argued that ESS can be regarded as an indirect source of knowledge for SE, where the non-educational knowledge is, by way of ETN, translated into educationally related knowledge. Instead of letting other disciplines rule over education, one thus allows SE itself to govern the knowledge production. This is part of safeguarding the autonomy of education. However, to ensure a self-governing discipline of education, one cannot only produce knowledge and theory indirectly through non-educational disciplines. If SE only had a mediating role among other disciplines, SE would be totally dependent on those other disciplines. All knowledge production would go about indirectly. SE should therefore be given space to work on its own, independently of ESS. A very important task to safeguard the autonomy of SE is to develop and produce knowledge and theory that is educationally unique.Therefore, educational-related concepts and situations should be researched directly from an educational perspective. Overall, SE should aim to develop, both theoretically and empirically, knowledge and theory being uniquely educational. Thus SE can stand forth as autonomous, as educators and educationists are not forced to being indirect, by borrowing ideas and theories from external sources. The question is how SE may be organised as being an autonomous discipline, producing knowledge and theory directly through education.

To address this question, one cannot overlook that education is a compound and complex discipline, including many research objects. For example, historical educational texts may be subjected to the development of educational theory (Benner, 2012; Tröhler, 2011), while educational policy documents may be subjected to critical assessments (Ball, 2017), etc. In this context, and for the sake of my argument, I will relate to EP as a research object and a direct source for the development of educational knowledge and theory. EP is a very complex field that can be understood in many different ways. For example, in the visible learning paradigm, EP can be understood in an instrumental and technical way, where the teacher strives to teach in such a way that the learning outcomes can be controlled and foreseen from the very beginning (Smeyers, 2006; Terhart, 2011, 2014; Wecker,Vogel, \& Hetmanek, 2017).

Following Kemmis (2012) and Kemmis and Edwards-Groves (2018), I stated in the introduction that EP is governed by two purposes, with one purpose related to individuals and another purpose related to the world. This double purpose of education is about the person and this person's relationship to the world. Specifically, there is an interrelated education consisting of an education for the good of the person and an education for the good of humankind. This means that teachers, in their attempts at achieving this double purpose, must act in certain ways, in interaction with the students (see Chapter 7 for an elaboration of the concept of EP).

\section{To think educationally about education}

ETK refers to reflections on EP conducted by researchers with the help of educational theory, hence making room to think educationally about education (Saeverot $\&$ Biesta, 2013). This is how educational knowledge is developed based on theory and reflection (Carr \& Kemmis, 1986; Cochran-Smith \& Donnell, 2006; 
Cochran-Smith \& Lytle, 1993; Stenhouse, 1975). ETK is notably a first-hand point of view, as the examination and reflection are rooted from the inside of practice itself, conducted by those who have direct access to EP (Flitner, 1966). Most often, teachers are the ones with direct access to the field of EP, but in some cases, for example, involving action research, educational researchers may have such direct access to EP. The aim is to develop and improve EP, which has a normative function, providing purposes and directions for the educational actions. ETK thus appears as a task and follows a logic where purposes and means are prominent. What should be? What kind of means should we use to get to where we want?

This backdrop reveals two differences between ESS and ETK. Where ESS thinks non-educationally about education as it provides room for studying EP from almost all sorts of disciplines, ETK thinks educationally about education as it examines EP based on an educational perspective. In other words, ETK examines EP by way of educational theory, thus developing knowledge that is educationally unique so as to ensure a direct line between ETK and EP instead of being forced to go indirectly through non-educational disciplines. As such, it is possible to safeguard the autonomy of SE.

In some cases, it may however be fruitful to take indirect turns. It may for example be beneficial to supplement the educational knowledge developed through EP with knowledge obtained from other disciplines. In such cases, ETN is relevant. For example, if it is appropriate to examine the individual in an educational situation, considered from the psychic side, psychological perspectives may be indirectly included in the educational research. In this respect, questions beginning with 'how' and 'when' may be appropriate. How do the students acquire knowledge? How do children learn reading skills? When should teachers begin with the basic reading lessons? When should teachers praise, and when should they criticise? From the perspective of the idea of education's autonomy, it is necessary to analyse and organise such indirect and psychological oriented questions, as well as problems and research results from the various perspectives of education (e.g. psychological and philosophical perspectives) into a functional unit in which education serves as an overarching frame. For example, the indirect means or the psychological oriented questions can be analysed and organised by way of different educational questions and interests, such as, how may students find their place in the world as subjects? How is it possible to conduct an education for the good of the person and an education for the good of humankind?

\section{Problems associated with the directness of ETK and the indirectness of ETN}

As stated earlier, ETK is a normative activity, as EP is studied on the basis of practice theory relating to norms or 'criteria'-for example, with contributions from John Dewey's pragmatic theory of education. ETK is reflective research in which scientific methods are used, such as phenomenological, hermeneutical and dialectical methods (which are often used in combination with each other; Flitner, 1966). The aim of ETK is ultimately to improve EP. 
However, there are several problems associated with ETK and ETN as well. Let us take a closer look at these problems before I in the next section (indirectness through ETH) put forward the argument as to how they may be solved.

On one hand, ETK has many advantages, not least that the research goes directly through education and that the researcher has direct insight into EP. On the other hand, this research contains many scientific problems and may therefore prevent the development of theory in a strong sense or theory that is well-founded (Kvernbekk, 2005, 2021). Thus, I shall argue that other forms of research, by way of an indirect approach, are needed beyond ETK's reflective research. The reason is that ETK produces educational theory in a weak sense (Kvernbekk, 2005, 2021). What do I mean by theory in a weak and strong sense? While theory in a weak sense may refer to perceptions or knowledge structures that are too loose or poorly articulated to be designed as strong theory, theory in a strong sense is knowledge which has undergone thorough scientific verification and substantiation in light of established theories and methods (Kvernbekk, 2005). As ETK produces weak educational theory, SE cannot rely on ETK alone. The weak theory that has been developed through ETK is in need of scientific support and processing through ETH, which produces strong educational theory.

In addition to the problem that the knowledge is insufficiently substantiated through ETK, another problem is that the researchers within this area of SE are so close to EP that they risk influencing the research with subjective beliefs (Farrimond, 2016). This can be explained by the distinction between an autobiography and a biography. Through the genre of autobiography, the authors write about themselves. Due to this writing from the inside, it is easy to colour the story with subjective beliefs and ideas. This is not a problem in the genre of biography because the main character of the story is described from the outside. In other words, there is a rather long distance between the author and the subjective and inner world of the main character (see Saeverot \& Kvam, 2019, for an elaboration of the autobiography and the biography perspectives in educational research).

There are also problems related to ETN, where translation processes of knowledge are based on other disciplines. While ETN turns to ESS for its development of knowledge, ETK turns directly to EP. ETN and ETK are therefore two different research processes that are often not connected. That said, to translate knowledge from other disciplines is highly demanding. As indicated earlier, ESS do not have a mediating role; the necessary space for indirectness is not there (Saeverot \& Biesta, 2013). Thus, educationists ought to develop a mediating competence, which corresponds to the ability to develop educational knowledge indirectly. In many contexts, ESS are characterised by an "unreflective eclecticism"-that is, an eclectic quest for knowledge from disciplines other than education, without conveying this knowledge directly into an educational framework (McMurray, 1955, p. 140; Tellings, 2001). We end up with non-educational knowledge which is produced from many places, and this makes it extremely difficult to translate knowledge from ESS into educationally relevant knowledge. Not only is knowledge on the discipline of education itself required, but knowledge in and on other disciplines is also required. 
As a way of solving these abovementioned problems, both ETK and ETN should be considered as indirect sources of strong theory. The practice-based knowledge and theory that has been developed by way of reflections (ETK) and the translated knowledge (ETN) should be examined in more detail, as these are weak theories of education. If we want the weak theory to be well and thoroughly articulated, and considered as strong theory, other and indirect forms of research are required. The weak knowledge or theory that has been developed requires theoretical processing. This is how the educational research becomes theory-based rather than practice-based. EP is no longer the direct research object. Rather, ETH examines EP indirectly, through ETK and ETN. The weak theories developed through ETK and ETN are now the new research object. As strange as it may sound, we end up with an education having no direct interest in practice.

Let me henceforth argue more profoundly as to how these abovementioned problems may be solved.

\section{Indirectness through ETH}

ESS often develop knowledge and theory for EP (Bellmann, 2017; Saeverot \& Kvam, 2019). This is a premise that remains in ETN. Hence, we gain knowledge or theory for education, as the knowledge is developed with a purpose of being used in EP. ETK in turn pays attention to the improvement of EP, whereas theory has a prescriptive and normative function, with an object to determine what should be. Important issues within ETK are thus often value-based. Are the desired values realised? Will children and young people realise their opportunities both as individuals and as members of community? It is about thinking with, and setting norms for, EP (Lochner, 1960). Common to both ETN and ETK is that they develop weak theories for education. There is something missing, as the knowledge has not been explicated theoretically. This means that the weak theory of ETN and ETK should be analysed and developed in detail so that the practice-based theory for education can become a strong theory of education. This can happen through ETH.

ETH's interest is not to improve practice. Within this sub-area of SE, theory's function is more descriptive, analytic and explanatory, where the object is to describe, analyse and explain what is and what has been. It is about showing and explicating a phenomenon which has to be explicated theoretically (Bellmann, 2017, p. 114). This part of the research is about developing educational theory in a strong sense. In other words, the weak theory developed by way of ETN and ETK will be made stronger by way of ETH. This indirect examination of EP will also strengthen $\mathrm{SE}$ as an autonomous discipline.

For example, ETH may be conducted by those who conduct the research directly in practice, in one and the same paper, or the research within ETH can be done by other educational researchers, preferably by several researchers. Rather than just replacing one educational theory with another, there is a "co-operative endeavor by many experts to build upon one another's findings and to pass them on for further refinements and additions" (McMurray, 1955, p. 131). 
As such, we have two widely differing views on education, one view with a direct examination of EP (ETK) and another view with an indirect look at EP (ETH). The question is how these two different approaches may relate to one another. Psychoanalysis may help to explain the relationship. From the inside (as a client) or from a direct point of view, one may understand the phenomenon (e.g. one's mental condition), but it may be hard to explain the phenomenon. From the outside (as an analyst) or from an indirect point of view, one may explain the phenomenon, but it may be difficult to understand the phenomenon. Through the interaction between the client, who understands the matter from the inside (directness), and the analyst, who explains the phenomenon from the outside (indirectness), a stereoscopic or a broader and more holistic perspective on the client's mental state can be developed.

The same can be said of the interaction between ETK and ETH, where the former is primarily based on understandings of EP, while the latter explains the knowledge developed by way of ETK. Let me offer an example, based on the findings presented in Chapter 2. Through ETK, there is an understanding that teachers often use direct pedagogy when students acquire knowledge, while indirect pedagogy is often used when teachers want to challenge students on a subjective-existential level. When this particular knowledge is examined through ETH, the researcher may apply certain theories and models that explain how underlying causes may lead to different patterns of action on the part of the teacher, in this case with regard to direct and indirect pedagogy. Another approach related to ETH may be that the researcher makes use of theories and models that explain different patterns of action based on teachers' intentions regarding their actions.

As the example implies, researching ETH is an indirect or second-order observation of EP, which has been examined via ETK and its direct reflections from within EP (Bellmann, 2017; Kemmis, 2012). Following Kemmis (2012), ETH takes the spectator perspective and ETK takes the participant perspective. The crucial point is that researchers working from the angle of ETH have to imaginatively take the perspective of those working from the angle of ETK so as to know what EP is about. This explains the indirect pathway from ETH, via ETK, to EP. In other words, to grasp the normative stakes relevant in education, the researcher as spectator has to imaginatively take the perspective of the researcher as participant. Metaphorically, it is like a detective who takes an indirect path by way of talking to witnesses in order to solve a crime (cf. Balzer \& Bellmann, 2017).

Although the researcher strives to be neutral and observational, prescribing and normative elements will be part of the theoretical explication, through subjective choices and assessments. It is not possible to be completely neutral and objective as an educational researcher. All those who research in the context of ETH must therefore have a critical viewpoint, not least aimed at their own research activities (Benner, Borelli, Heyting, \& Winch, 2003). For instance, the critique could be aimed at educational methods and guidelines which are based on political and/or ideological views (Saeverot \& Torgersen, 2021). Alongside this self-criticism, researchers must also be open to criticism from other researchers (Oancea, 2005).

Last but not least, ETH is motivated by questions of truth (Sünkel, 2013). By truth I do not mean a universal truth. Truth in the context of ETH emerges by 
examining both ETN and ETK (not at the same time, as ETN and ETK are two different research processes that are often not connected). What proves to be valid, either on a small or big scale, is regarded as truth, which is valid until it is modified or completely falsified by new investigations. Examples of questions of truth may be as follows: How may the practice-based knowledge/ weak theory become valid (in a strong(er) sense)? Is it possible to generalise the practical-educational knowledge? Can that which has been learnt on a rather small scale (which includes the feature of validity on a small scale) be related more broadly? By way of different and suitable theories and methods - for example, explanatory theories and observations - the researcher strives to investigate whether the practice-based knowledge may be valid or not. In the end, the findings from ETH, or the strong educational theory, may indirectly inform, and perhaps impact, teachers' actions conducted in EP (Kvernbekk, 2016).

\section{SE emerges as an autonomous discipline through the combination of directness and indirectness}

I have argued that SE can emerge as a strong and autonomous discipline by combining direct and indirect routes in educational research. This is illustrated in Figure 6.1.

A part of the argument is that EP is a research object that can be examined for the purpose of producing knowledge. I have argued for two different research processes of EP. The first research process examines EP through ESS, which develops knowledge and theory from EP based on a variety of disciplines. Since ESS do not generate educational knowledge, this knowledge is considered as an indirect source of knowledge, as it needs to be translated into educationally relevant knowledge through ETN, which in turn must be verified through ETH. Although this indirectness or translation helps to safeguard the autonomy of SE, the latter is still dependent on other disciplines. Hence, SE is not entirely self-governing.

If education is to become a self-governing discipline, a discipline that is independent of other disciplines, that would require examining EP from the point of view of education, in addition to the examining of EP from the point of view of psychology, sociology, philosophy and other disciplines. It is about thinking educationally about education. This happens through ETK, which is the second research process that I have described. What characterises ETK is that it produces educational knowledge directly from EP. Although SE is independent of other disciplines in this way, the educational knowledge that is developed is relatively weak. Hence, there is a need to strengthen this knowledge, so as to make it into an educational theory in a strong(er) sense. As such, ETK is considered as an indirect source of knowledge for ETH. Educational theory is thus developed through (1) ETK as a first-hand experience in which practice-based knowledge and theory are derived directly from EP and through (2) ETH as a second-hand experience in which theory-based knowledge is derived indirectly from EP and directly from practice-based knowledge. ${ }^{1}$

In this direct-indirect way, SE can appear as a strong and self-governing discipline, with the right to organise its own activities and make independent decisions. This 
not only avoids the problem consisting of other disciplines invading education with their perspectives, but it also entails that education has something unique to offer research in and on EP, alongside unique contributions from other disciplines.

However, the educational theory which is produced can never be absolutely true or valid. Given this, I suggest that educational researchers take the role of ironists, who, according to Rorty (1989, p. 74) "are subject to change, always aware of the contingency and fragility of their final vocabularies." 2 The educational theory can only be temporarily true. This means that the educational theory must always be re-examined whenever new information, knowledge and insights occur. In some cases, educational theory may have to be re-described on the basis of new findings, or as McMurray (1955, p. 133) points out, the "obligation of an educational theorist is to refine the vocabulary of his own discipline." In other cases, the educational theory may even be completely rejected. New documentation, as well as critical and confrontational observations, can reveal weaknesses of the educational theory and perhaps force the researchers to re-describe or reject that which has been considered as established knowledge. It is now time to look closer at the educational researcher as an ironist in the following chapter.

\section{Notes}

1 This process of knowledge production can be found in the Continental Pädagogik tradition or, more specifically, what in Germany is called Erziehungswissenschaft. However, this tradition is under pressure, inter alia, from ESS (Bellmann, 2017).

2 The idea of the educational researcher as ironist will be elaborated on in the next chapter.

\section{References}

Arcilla, R. (2002). Why aren't philosophers and educators speaking to each other? Educational Theory, 52(1), 1-11. https://doi.org/10.1111/j.1741-5446.2002.00001.x

Ball, S. (2017). The education debate. Bristol: Policy press.

Balzer, N., \& Bellmann, J. (2017). Die Erziehung der Theaterperspektive. Zur Kritik de Dichotomisierung von Pädagogik und Erziehungswissenschaft. [The education of the theater perspective. A critique of the dichotomy of pedagogy and educational science]. Paper presented at Deutsche Gesellschaft für Erziehungswissenschaft, 8-10 March 2017, Phillips-Universität Marburg.

Bellmann, J. (2017). Forwards to the learning sciences or back to pedagogy? In H. Saeverot, \& T.Werler (Eds.), Pedagogikkens språk [The language of education] (pp. 104-117). Oslo: Gyldendal. Benner, D. (2012). Allgemeine Pädagogik. Eine systematisch-problemgeschichtliche Einführung in die Grundstruktur pädagogischen Denkens und Handelns [General pedagogy. A systematik-problemoriented introduction in the foundational structures of pedagogical thinking and action]. Weinheim: Juventa.

Benner, D., Borelli, M., Heyting, F., \& Winch, C. (Eds.) (2003). Kritik in der Pädagogik. Versuche über das Kritische in Erziehung und Erziehungswissenschaft. [Critique in pedagogy. Attempts at critical aspects in pedagogy and the science of education]. Weinheim: Beltz Verlag.

Biesta, G. (2011). Disciplines and theory in the academic study of education: A comparative analysis of the Anglo-American and Continental construction of the field. Pedagogy. Culture \& Society, 19(2), 175-192. 
Biesta, G. (2014). The beautiful risk of education. Boulder \& London: Paradigm Publishers.

Biesta, G., Allan, J., \& Edwards, R. (2014). Introduction. The theory question in education and the education question in theory. In G. Biesta, J. Allan, \& R. Edwards (Eds.), Making a difference in theory (pp. 1-9). New York \& London: Routledge.

Carr, W., \& Kemmis, S. (1986). Becoming critical: Education, knowledge and action research. London: Falmer.

Cochran-Smith, M., \& Donnell, K. (2006). Practitioner inquiry: Blurring the boundaries of research and practice. In J. L. Green, G. Camilli, \& P. B. Elmore (Eds.), Handbook of complementary methods in education research (pp. 503-518). Mahwah, NJ: Lawrence Erlbaum Associates.

Cochran-Smith, M., \& Lytle, S. L. (1993). Inside/outside: Teacher research and knowledge. New York: Teachers College Press.

Dale, E. L. (2005). Kunnskapsregimer i pedagogikk og utdanningsvitenskap [Regimes of knowledge in pedagogy and educational sciences]. Oslo: Abstrakt forlag.

Dewey, J. (1929). The sources of a science of education. New York: Liveright.

Farrimond, H. (2016). The ethics of research. In D. Wyse, N. Selwyn, E. Smith, \& L. E. Suter (Eds.), The BERA/SAGE handbook of educational research (pp. 72-89). London: Sage.

Flitner, W. (1966). Das Selbstverständnis der Erziehungswissenschaft in der Gegenwart [The selfunderstanding of educational science in the present time]. Heidelberg: Quelle \& Meyer.

Kemmis, S. (2012). Researching educational praxis: Spectator and participant perspectives. British Educational Research Journal, 38(6), 885-905.

Kemmis, S., \& Edwards-Groves, C. (2018). Understanding education. History, politics and practice. Berlin: Springer.

Kristensen, J. E. (2017). Samtidsdiagnostik, videnspolitik og kritik: med særligt henblik på uddannelse og uddannelsesvidenskab [Contemporary diagnosis, knowledge policy and critique, with a special focus on education and educational sciences]. In A. K. Ljungdalh, J.A. Lysgaard, \& O.A.Tafdrup (Eds.), Uddannelsesvidenskab: en kritisk introduktion [Educational sciences: A critical introduction] (pp. 15-50). Frederiksberg: Samfundslitteratur.

Kvernbekk, T. (2005). Pedagogisk teoridannelse [Construction of pedagogical theory]. Bergen: Fagbokforlaget.

Kvernbekk, T. (2016). Evidence-based practice in education. Functions of evidence and causal presuppositions. New York \& London: Routledge.

Kvernbekk, T. (2021). The nature of educational theories. Goal-directed, equivalence and interlevel theories. New York \& London: Routledge.

Lexico (2020). Autonomy. Available at: https://www.lexico.com/definition/autonomy, accessed 10 November 2019.

Lochner, R. (1960). Zur Grundlegung einer selbständigen Erziehungswissenschaft [Foundations for an independent science of education]. Zeitschrift für Pädagogik, 6(1), $1-21$.

McMurray, F. (1955). Preface to an autonomous discipline of education. Educational Theory, 5(3), 129-140.

Oancea, A. (2005). Criticisms of Educational Research: Key topics and levels of analysis. British Educational Research Journal, 31(2), 157-183.

Prange, K. (2005). Die Zeigestruktur der Erziehung [The pointing structure of education]. Paderborn: Ferdinand Schöningh.

Rorty, R. (1989). Contingency, irony, and solidarity. Cambridge: Cambridge University Press.

Ruitenberg, C. W. (2009). Distance and defamiliarization. Translation as philosophical method. Journal of Philosophy of Education, 43(3), 421-435. 
Saeverot, H., \& Biesta, G. (2013). On the need to ask educational questions about education. Policy Futures in Education, 11(2), 175-184.

Saeverot, H., \& Kvam,V. (2019). An alternative model of researching educational practice: A pedagogic-stereoscopic point of view. British Journal of Educational Research, 45(1), 201-218.

Saeverot, H., \& Torgersen, G.-E. (2021). SSE-based frame of reference. Outlines for a global curriculum: Turning existential threats into resources. In H. Saeverot (Ed.), Meeting the challenges of existential threats through educational innovation. A proposal for an expanded curriculum (pp. 11-26). New York \& London: Routledge.

Säfström, C. A., \& Saeverot, H. (2017). Doing harm to educational knowledge:The struggle over teacher education in Sweden and Norway. In M. Peters (Ed.), A companion to research in teacher education (pp. 179-191). Berlin: Springer.

Skjervheim, H. (1995). Eit grunnproblem i pedagogisk filosofi [A basic problem in the philosophy of education]. In H. Skjervheim (Ed.), Deltakar og tilskodar og andre essays [Participant and spectator, and other essays] (pp. 214-229). Oslo:Tanum-Norli A/S.

Smeyers, P. (2006). The relevance of irrelevant research; the irrelevance of relevant research. In P. Smeyers, \& M. Depaepe (Eds.), Educational research:Why "What Works" doesn't work (pp. 95-108). Dordrecht: Springer.

Stenhouse, L. (1975). An introduction to curriculum research and development. London: Heinemann.

Su, H., \& Bellmann, J. (2018). Inferentialism at work:The significance of social epistemology in theorising education. Journal of Philosophy of Education, 52(2), 230-245.

Sünkel, W. (2013). Erziehungsbegriff und Erziehungsverhältnis [Concept of education and educational relationship]. Weinheim: Beltz.

Tellings, A. (2001). Eclecticism and integration in educational theories: A metatheoretical analysis. Educational Theory, 51(3), 277-292.

Terhart, E. (2011). Has John Hattie really found the holy grail of research on teaching? An extended review of Visible Learning. Journal of Curriculum Studies, 43(3), 425-438.

Terhart, E. (Ed.) (2014). Die Hattie-Studie in der Diskussion: Probleme sichtbar machen [Discussion of the Hattie Study: Making problems visible]. Seelze: Kallmeyer, Klett.

Trippestad, T. A., Swennen, A., \& Werler, T. (Eds.) (2017). The struggle for teacher education. International perspectives on governance and reforms. London: Bloomsbury Academic.

Tröhler, D. (2011). Languages of education. Protestant legacies, national identities, and global aspirations. New York \& London: Routledge.

Wecker, C., Vogel, F., \& Hetmanek (2017). Visionär und imposant - aber auch belastbar? [Visionary and impressive - but also reliable?] Zeitschrift für Erziehungswissenschaft, 20(1), 21-40. https://doi.org/10.1007/s11618-016-0696-0

Wulf, C. (2003). Educational science. Hermeneutics, empirical research, critical theory. New York \& Munich:Waxmann. 


\section{The educational researcher Ironic indirection and the ' $l$ ' in education research}

\section{Introduction}

In recent years, several trends have evolved in education research involving educational practice (EP). For example, there has been an increase in the idea of evidence-based practice, meaning that practice shall be based on evidence. Research then seeks to evidence-base its results, such as which kind of learning works in practice (Kvernbekk, 2016; McCardle \& Miller, 2009; Thomas \& Pring, 2004). The fundamental question when it comes to the idea of evidence-based practice is how to obtain sufficiently reliable information about whether an educational intervention is true and preferably is working in the field of practice. If, for example, research suggests that a certain method of learning is effective, say direct instruction, it may be deemed evidence-based (Cf. Elliott, 2004). Achinstein (2001), Kelly (2008) and Kvernbekk (2016) acknowledge the concept of evidence by defining it as that which either serves to confirm or disconfirm a claim, belief or hypothesis, or a theory in general. However, what these researchers seem to neglect is that the very concept of evidence implies a positivist approach to research whereby the researcher believes that reality can be grasped and understood at face value by way of using objective and value-neutral observations (see Pirrie, 2001; Simons, 2003; Smeyers \& Depaepe, 2006; Biesta, 2007, 2010; Bellmann \& Müller, 2011; Terhart, 2014 for a more detailed and critical analysis of research that seeks evidence).

This belief in reliable information and evidence, so I shall argue, creates problems from two perspectives - that is, an outside-in and inside-out perspective. These perspectives can cause problems which may have unfortunate consequences for EP (Malone \& Hogan, 2020). Let me clarify these problems from the two perspectives.

Following Biesta (2008), a tendency in the idea of evidence-based practice is thus: Once reliable information has been obtained by way of research, it can be extrapolated more or less directly to the field of EP.This implies that the evidencebased results are more or less meant to dictate EP activities. The researcher posits most of the control. It is the researcher's task to find evidence that teachers and practitioners can use to change and improve EP. It gives us an outside-in perspective in that the evidence-based information or theory, which is acquired externally, should directly affect EP. However, educational research and EP are two different 
things, with different languages and mindsets; hence, the evidence-based results should find their way to EP indirectly by way of critical awareness (Biesta, 2008; Kvernbekk, 2016; Saeverot \& Kvam, 2019).

The problem from the second perspective has to do with the tendency to conduct research from within practice itself, so-called teacher or practitioner research-which I classed as ETK in the previous chapter. As I also pointed out in the previous chapter, it is not just teachers and practitioners who carry out research in this way. Educational researchers may also conduct such research - for example, through action research. Since the data is derived directly from EP, it can be described as having an inside-out perspective. The problem here is that teachers and practitioners have to depend on weak theories, which I elaborated on in the previous chapter.The information obtained from EP is reflection-based and is believed to be reliable information, even if the information or theory is weak or lacks thorough scientific verification and substantiation.

Due to these problems, or the omniscience in education research, I suggest connecting irony to the research process. Kierkegaard, too, suggested a connection between irony and scientific research. At the end of his dissertation on the concept of irony, Kierkegaard accuses the research of his time of being too preoccupied with results (Kierkegaard, 1992a, p. 328), and that researchers relate to objective truths without further thoughts — as they are so impatient. He also claims that "scientific scholarship mediates all the opposites" (ibid.). Here irony can be helpful, according to Kierkegaard, as irony can discipline the researcher; make them less results-oriented and more process-oriented.

My argument is based on the fact that irony goes two ways. On the one hand, irony goes from sender to receiver. The irony points outwards and has an effect on the recipient or the thing (e.g. a research paper, a movie, work of drama) that is put under the ironic lens. On the other hand, irony returns, it points inwards and has an effect on the sender. A brief explanation of this, before I elaborate, is that irony pointing outwards can disturb and unsettle fixed ways of thinking (Roberts \& Saeverot, 2018) by provoking paradoxes, contradictions and inconsistencies in the research itself so that the researcher can have a new look at what was considered evidence. Irony pointing inwards may, if it is put under control, operate as "a disciplinarian" (Kierkegaard, 1992a, p. 326). Through irony, the researcher may have their confidence and self-satisfied certainty disturbed and unsettled-which can forestall the drive for certitude and homogeneity (Smith, 2020).

We must not however overlook that research in general includes doubt and criticism, among other things, which are important components that should permeate all research. The point of this chapter is not to replace such components with irony. Rather, I propose using ironic indirection to support or supplement the fundamental criterion of taking a doubting and critical approach to research.

This has to do with the fact that irony does not seek results, whether to understand or to criticise from a predetermined point of view. According to Kierkegaard, irony can be defined as "infinite absolute negativity" (Kierkegaard, 1992a, p. 261). An example of this is that jest hides in seriousness and seriousness in jest. Ironists can thus combine opposing and conflicting things in their communication-be it jokes and seriousness, or praise and criticism-in such a way that it is impossible to 
conclude whether the ironists are joking or being serious or whether they are praising or criticising. Such a form of irony is therefore an indirect component because it never goes straight ahead. I refer to this form of irony as ironic indirection, just like I did in Chapter 3. Beyond this brief outline of irony, I will gradually define the concept of irony, which, I hope, will become clearer as the chapter progresses. But before I elaborate on ironic indirection in education research I want to look more closely at the outside-in and inside-out perspectives and the problems surrounding the belief in reliable information and evidence, which will form a background and legitimation of the use of ironic indirection in education research.

\section{The omniscience in education research-some problems}

A great deal of today's education exists in what Biesta (2010) has described as the "age of measurement", where the focus is on measuring things such as learning outcomes. We have seen an increase in research both from the inside-out perspective - for example, action research — and the outside-in perspective-for example, research seeking evidence. A great deal of modern education research concerns itself with what is reliable and precise, with the consequence that the field of psychology is often hailed as a role model for research in education (Bellmann \& Müller, 2011; Ljungdalh, Lysgaard, \& Tafdrup, 2017). Just as psychology is seemingly able to generate concrete and unambiguous results, the educational researcher should seek to uncover reliable information but also information that is deemed to be useful. Anything that does not fall within the boundaries of usefulness is therefore considered to be useless (Smeyers, 2006). For example, focusing on ambiguities, such as the inner self, is of little or no use to a positivist mindset. Instead, the belief that research data can reflect reality is upheld so that this data can be directly extrapolated to EP. This happens either from the inside or from the outside of EP. Let us, therefore, take a closer look at these two perspectives and the problems that may arise in EP.

\section{The outside-in perspective and problems related to EP}

The outside-in perspective is often equivalent to research about or on EP (Kemmis, 2012). This means that the research object that is observed or made subject to examination-EP-is seen from a distant perspective (Tenorth, 1994, p. 23; Balzer \& Bellmann, 2017). As a concrete example of this, we can look at John Hattie's research, by way of analysis and summary of more than 800 meta-analyses of school performance. As he specifies in the preface to his book Visible Learning, he has not entered classrooms directly with a goal of capturing the nuances and details of what takes place (Hattie, 2009, p. viii). Instead, he has chosen a quantitative research approach in which statistics are central (ibid., p.ix). Hattie has thus studied EP from a distance - that is, indirectly through thousands of different research studies. By using an external and indirect perspective, he has been able to compile over 800 meta-analyses to find and explain what is working to improve learning in schools (ibid., p. 3-4). In other words, research on EP has neither direct insight into nor direct experience of what takes place in EP. 
Despite the fact that research on EP in this way is indirect and equivalent to a second-order or external-order observation of EP, it is implied that the findings of this research — namely, what works in terms of student learning outcomes—should provide guidance for teachers and practitioners. However, a downside to research done indirectly from a deliberate distance is that the research may not be relevant for those who are involved in EP.There are many examples of teachers and practitioners feeling like their voices and views about EP have been overshadowed by empirical and evidence-based data.

For example, Stephen Kemmis (2012) points out that it has been far from an unbridled success. Rather, teachers and other practitioners, "have frequently felt themselves silenced by conventional research knowledge, and they continue to turn their back on it and on the conferences and journals in which it is reported" (ibid., p. 893). The point being that the evidence-based data have a tendency to speak on behalf of practitioners. This happens despite that it is difficult, if not impossible, for the distanced researcher to capture the 'essence' of what takes place in EP (ibid.). Nevertheless, research strives to influence EP directly by way of evidence-based data (Malone and Hogan, 2019).

Brezinka (2015, p. 294), who comments on the continental Pädagogik tradition, concludes, like Kemmis (2012), that a gap has emerged between researchers and practitioners in schools. According to Brezinka (ibid.), this gap has to do with researchers using a language that does not resonate with the language used by practitioners. Empirical research involving the evidence-based perspective remains too abstract and is therefore unable to capture the concrete challenges and issues that practitioners must handle daily. Part of the problem may lie in the characteristics that are inherent to research-based theories.

To this Kvernbekk $(2001,2005)$ clarifies that research-based theories are characterised by being context-free, abstract and providing simplified models of complex educational phenomena, while EP involves far more aspects than such research-based theories can grasp. It may therefore be a challenging task to use research-based theories directly in EP. Theories have no practical relevance in and of themselves: the relevance must be established on the foundation of a critical and tactful assessment, based on direct and first-hand knowledge of each educational situation (Kvernbekk, 2001, pp. 33f; Kvernbekk, 2005, p. 181). As the indirect research on EP is not directly relevant to EP, a direct and first-order examination of EP is also needed. Thus, research from a distance may be relevant to EP, although there are still many uncertainties. One cannot be sure that research on EP is relevant to practitioners even if they have obtained first-order knowledge directly from EP.

\section{The inside-out perspective and problems related to EP}

In addition to research on EP, there is research in EP, which I referred to as ETK in the previous chapter. In this inside-out perspective, the belief in reliable information is also apparent but in a slightly different way than is the case in research on EP. Let me elaborate on this. By engaging in research in EP, the researcher is presented 
as a subject in which EP becomes an object of reflective research. The practitioners as researchers either have a direct or first-person perspective in relation to their own practice (singular) or a direct or first-person perspective in relation to a shared practice (plural) in which practitioners as researchers appear as interlocutors (Kemmis, 2012). This means that the subjects that research their own (individual or collective) practice have the opportunity to develop knowledge directly anchored in their own practice.

A concrete example of this is the teachers who research their own practice (Stenhouse, 1975). Over the last decades, "teacher research" (Cochran-Smith \& Donnell, 2006; Cochran-Smith \& Lytle, 1993), also more commonly referred to as "practitioner research" (Borko, Liston, \& Whitcomb, 2007), has been highlighted in international research as relevant ways of developing knowledge. In particular, action research has emerged in recent years as a significant methodology for such development of knowledge. According to the research literature, action research does connect practice and theory (Carr \& Kemmis, 1986; Kemmis, 1988; Kemmis, 2009; Ulvik, Riese, \& Roness, 2017), making teachers think and act like researchers with a positive impact on EP (Davis, Courtney, \& Broome, 2018) while being a tool for professional development (Ulvik \& Riese, 2016). In The SAGE Handbook of Action Research: Participative Inquiry and Practice (2008), action research is described as a form of systematic development of knowledge-that is, practically based knowledge (Reason \& Bradbury, 2008, pp. 1-10).

If we consider research in $\mathrm{EP}$ in a broad and general sense, we can claim that this perspective provides good opportunities to produce direct and valuable insights regarding EP. At the same time, this research also has some clear limitations, especially in that research aiming to improve EP may become too normative and too subjective. For example, Bellman (2017, p. 106) notes that pedagogy interpreted as practical theory generated by those involved in EP amounts to "normative projects for the practice and discourse of education, implying premises that ought to be investigated carefully before we buy into them." All research in the social sciences and humanities - both quantitative and qualitative research-is, of course, normative to some degree, but the normative implications of the research may have different degrees. Some normative research studies may simply be too prescriptive, with the result that both the research object and the data material become too influenced by preconceived ideas. The main problem with research in EP is that the information that is being developed is far from reliable. Not only is there a danger that the information is coloured by normative and subjective perspectives, but the information or theory is, as I argued in the previous chapter, weak in the absence of further scrutiny through ETH.

\section{Educational research in and on EP}

Though research on EP clearly differs from research in EP, especially in terms of the researcher's distance to the research object, as I have pointed out, the two perspectives have the following two interrelated similarities: they (1) have a direct interest in practice and (2) are governed by one and the same objective, which is mainly to 
improve practice. In the preface to the Norwegian edition of Hattie's previously mentioned book, Visible Learning, the author underlines that the two aforementioned points do apply to the outside-in-perspective: "The question that is highlighted throughout is: what impacts learning?” (Nordahl,2013,p. 17; my translation). Implicitly, this tells us that the objective of the research is to "improve the teaching" (ibid., p. 20; my translation). The direct interest in practice and the objective of improving practice is also key to the inside-out-perspective, which is emphasised in the final chapter of an anthology entitled The teacher as researcher. Therein the authors specifically discuss practice-oriented research and action learning, in which learning is "future-oriented in form. It seeks changes in the meaning of the "the best option at any given time"” (Tiller \& Brekke, 2017, p. 282; my interpretation). Another recent book on action research takes the same point of view, claiming that action research "can contribute to professional development and improved practice” (Ulvik, 2017, p. 17; my interpretation; see also Ulvik \& Riese, 2016).

Research both on and in EP is about extracting theory to change and improve EP. The researcher believes that EP can be mastered and controlled using theory developed either indirectly through meta-analysis and other methods or directly through action research and other methodologies (cf. Biesta, 2008). Both perspectives are to certain degrees dominated by the belief in reliable information-which is believed to improve EP.

I will thus turn to irony which can unsettle the omniscience in education research, regarding both the outside-in and the inside-out perspective. Using ironic indirection to support or supplement the fundamental criterion of taking a doubting and critical approach to research can engender a research perspective based on indirectness which educational research, both educational research in and on EP, can 'benefit' from. Let us, therefore, take a closer look at the connection between irony and educational research.

\section{Ironic indirection}

As I mentioned in Chapter 3, there are many forms of irony, and before anything else, we should address what kind of irony I intend to relate to educational research. As I also pointed out in Chapter 3, the word 'irony' comes from the Greek eironeia, implying deception and feigned ignorance. Notice that it does not involve hiding something before then revealing it-by saying the opposite of what we mean, for instance. This is a tasteless form of irony, which poses a danger in a communication setting (including education). This is partly because this form of irony can make recipients who do not understand the irony feel stupid, with the result that they are suppressed and excluded rather than allowed to develop. Similar problems may occur in a research context. One simply replaces one truth with another, but that does not take us any further. To counter this form of tasteless irony, I should like to posit Kierkegaard's form of irony as the negative, meaning that it is the way, not the truth or end result (Kierkegaard, 1992a, p. 327). As such, irony intervenes without seeking a truth or a result-e.g. to understand, as is the case of hermeneutics (cf. Gadamer, 1965; Ricoeur, 2016). 
This form of irony can also intervene both on the outside and on the inside. On the one hand, irony can point outwards, affecting the receivers of irony, and on the other hand, irony can point inwards, affecting the ironists themselves. What I am about to argue is that irony pointing outwards can be used with regard to the research itself. For example, irony pointing outwards may reveal faults and limitations in that which is regarded as evident or true. Irony can thus function as a meta-perspective on research activities through which irony can disturb fixed thoughts by way of provoking inconsistencies and paradoxes, and perhaps unsettle things that have become stuck, such as prejudice, delusions, biases and so on.

It is thus tempting to link irony to ETH (see Chapter 6) since it is a matter of 'thinking' about a thinking or, more specifically, a meta-perspective on research that has been carried out. However, ironic indirection is not about reaching a truth, nor is it about improving or changing something. Rather, irony as the negative creates a kind of hyper-intensifying change that is in constant tension and motion (Kierkegaard, 1992a, p. 121). It implies reinforcing and potentiating friction and movement rather than harmonising them (whereby something abstract is transformed into something concrete or something unknown is made known, etc.; ibid.).

As I stated earlier, irony can also point inwards towards the researchers themselves. For example, Kierkegaard (1992a, p. 327) suggests that irony can be "an excellent surgeon." This means that irony can, so to speak, cut away all the wild shoots on the researcher. If irony is controlled, it can discipline and educate the self (ibid., p. 326), including the research subject. Irony may provide a meta-perspective on one's actions, be it choices, analyses and so on. Metaphorically, irony appears as a mirror in which the researchers can see themselves. The researchers, and consequently the entire research work, may then be disciplined.

In the following, I will try to argue more fully as to how irony can point outwards and inwards, as a way of unsettling the omniscience in education research, which in turn can give different effects, both before, during and after the research.

\section{Irony pointing outward-destruction and hyper-intensifying change}

We should first be aware that there is no face behind the mask of ironists (Kierkegaard, 1992a). This means that ironists ask questions without having the answers in advance- - "Inasmuch as I ask a question, I know nothing” (Kierkegaard, 1992a, pp. 34-35) - and does not, therefore, have the new in their power. Nonetheless, one effect of irony pointing outwards is that it can unlock things that have become stuck and destroy fruitless perspectives and practices. This can be done in a variety of ways, including by responding ironically to that which is taken for granted in order to provoke such things as doubts, paradoxes and so on. It is important to stress that this type of irony should not be equated with the form of critique that judges an action or a work according to specific criteria, often with a view to changing them. Ironic indirection, on the other hand, lets that which already exists exist, but by acting in this passive-active way, it can still be destroyed. 
However, it is not about defeating that which already exists. A researcher who wants to defeat the existing, or that which is taken for granted, sees a weakness in the existing compared with the new. Underlying these assessments is a quantitative and homogeneous view of time which is direct and linear because the researcher claims to have the future - that is, the new that will defeat the existing - in their power. But since the ironists do not have the new in their power, we must ask how they will be able to destroy the existing. Let me cite a couple of examples from Kierkegaard before concretising these examples by looking at education research.

In the first example, Kierkegaard refers to John the Baptist who "was not the one who was supposed to come; he did not know what was to come-and yet he destroyed Judaism. Thus he destroyed it not by means of the new but by means of Judaism itself" (Kierkegaard, 1992a, p. 263). John demanded of Judaism what it wanted to offer-namely, justice. That way, he allowed the existing to continue to exist. Yet since Judaism could not offer justice, according to Kierkegaard (ibid.), John let Judaism be destroyed. The effect of this form of irony can be linked to time as a form of heterogeneity, that is, a concept of time as something that is approaching (cf. Levinas, 2000). It is a case of an entirely surprising future which arrives on the basis of what already exists, and upon the arrival of the new, the existing is destroyed.

A second example of such destruction by way of irony is Kierkegaard himself when faced with the works of Georg Wilhelm Friedrich Hegel (1770-1831). Kierkegaard encountered a problem in that Hegel had created an all-seeing system which, metaphorically, all but swallowed everything it came across. How should he meet this theoretical and philosophical system? What if he chose to respond to it with criticism or a counterargument, then what? He would have been swallowed up, become part of Hegel's philosophical system or simply ended up as a paragraph in the big system (Kierkegaard, 1992b). Kierkegaard, therefore, had no choice but to take on Hegel's system with an indirect approach that was unassailable. Kierkegaard chose irony on this occasion (and similar rhetorical devices such as humour), which allowed him to get inside Hegel's system while unsettling, destroying and creating indeterminate smiles and laughter in response to this seemingly perfect system without making himself approachable. As incredible as it may sound, this process of destruction had happened without expectations, criticisms and counterarguments from Kierkegaard's side.

Let us also have a brief look at Kierkegaard where he warns against communicating directly with persons who think they are Christian but perhaps do not act as Christians. According to Kierkegaard one should not say, "I am Christian, you are not a Christian" (Kierkegaard, 1998, p. 54). This is a form of directness which according to Kierkegaard can generate negative emotions in the recipient. Kierkegaard proposes to instead turn the whole thing on its head by speaking indirectly, and ironically, like this: "You are a Christian, I am not Christian" (ibid.). This way, Kierkegaard lets the existing continue to exist by accepting that the other party is a Christian, even though that may not be the case, according to Kierkegaard. It is almost the same as saying, "You are right, I am wrong," thus destroying and unsettling the injustice perpetrated by the other person. 
This form of irony can be used in a research situation where the researcher reviews the results. Instead of reading the results critically, the ironist researcher reads what is written verbatim. In this way, both comic, absurd and meaningless contents may appear by themselves. It is as if the result section reveals its nonsensicality by itself. Using irony, the researcher then lets the existing go to ruin.

The same kind of irony may also give rise to thoughts that have hitherto been out of reach. Such things may happen even if the researcher has been neither calculating nor normative, or direct like a calculating matrix. Rather than surround itself with common sense and theoretical rationality, Kierkegaardian irony is highly indirectcloser to irrationality, even though it cannot be said to be exactly that, either. For Kierkegaard, irony is in itself "like a riddle", quite unlike certain theories that forge straight ahead without detours and digressions (Kierkegaard, 1992a, p. 248). Instead, irony exists somewhere between the determinable and the indeterminable. Irony constantly shifts between these two extremities, which then become imbued with instability. For that reason, irony does not fit the criteria for conventional theory. It defies the aspects of precision and truth that exist in conventional theory and research seeking evidence by evading any attempt at conventional and transparent questioning - whereupon all forms of rationality fall apart (cf. Roberts \& Saeverot, 2018).

Yet we cannot use this one form of irony as a means of effecting change in research for evidence, say, in a way that turns disharmony into harmony, balance and equilibrium. If we are going to talk about change as a result of ironic indirection at all, it must be, as I stated earlier, in the form of hyper-intensifying change that remains in constant tension and motion. This has to do with the fact that this form of irony does not invite reconciliation as it "reinforces vanity in its vanity and makes what is lunatic even more lunatic" (Kierkegaard, 1992a, p. 257). It has no need whatsoever to create harmony, instead allowing the mysterious to thrive. Let me explain this by comparing irony and hermeneutics.

Where hermeneutics risks restricting, reducing and even distorting that which is new and unknown by wanting to make the new and unknown known and understandable (cf. Gadamer, 1965), the ironic perspective allows us to reinforce and potentiate tensions and motions. In turn, this has to do with how irony intervenes without seeking to understand - quite the antithesis to the goals of hermeneutics and traditional education. A typical hermeneutist, for example, will assert that we express ourselves, in writing or verbally, in order to be understood (cf. Michelfelder \& Palmer, 1989). The ironists, on the other hand, have no desire to be understood and do not strive for either consensus or reconciliation. Thus, the ironists avoid ending up in one form of universal synthesis or another. The questions are more important than the answers to the ironists-who in a childlike sense are inquisitive and doubting, just as much of their own views as those of others (Rorty, 1989). By posing ironic questions in light of education research, we can challenge that which is universally seen as evident and true, but never in a way that leaves us with an understanding or clear-cut answers.

Looking at modern educational research, there is an increasing tendency to produce a concrete result, something useful, an outcome that it can somehow use constructively in an EP setting (Eraut, 2004). It can be research into assessment for 
learning, where the results of the research should be converted as directly as possible into EP. Irony, meanwhile, does not produce concrete results. Instead, when irony has been applied, we are left with various contrasts and disagreements rather than unambiguous conclusions, concurrence and evidence. Irony will never take us to a place where we can conclude that something has been dealt with and defeated, as though we have achieved a synthesis between the determinable and the indeterminable.

\section{Irony pointing inward-governance and self-education}

Ironic indirection can also point inwards, as it returns to the ironist. This way, irony may educate the ironists themselves. Irony covered in the fields of philosophy and educational philosophy has often overlooked or marginalised this aspect (Cf. Lear, 2011; Nehemas, 1998; Smeyers, 2005; Smith, 2020; van Goor \& Heyting, 2006; Vasiliou, 2002;Vlastos, 1991). Instead, these fields have mostly been concerned with the educational effects of irony on the recipients without taking into account the fact that irony can also have an educational effect on the person who applies the irony.

Kierkegaard is an exception when he talks about "Governance" (Kierkegaard, 1998, p. 76). The Governance Kierkegaard refers to primarily exists in his own writings so that what he has written appears to him to have the potential for education. This sounds paradoxical since it is Kierkegaard himself who has written the texts, while the texts are assigned a language and meaning that goes above and beyond his intentions and objectives. Because of the existence of Governance and counter-thinking, the author's or creator's authority is both undermined and threatened in some way. More precisely, it happens by way of the excess meaning that is mysteriously assigned to the texts - that is, excess meaning which may be significant to the creator's self-knowledge and self-criticism. This is a form of irony as the negative, which offers a plurality of voices because there is a contradiction between Kierkegaard and Governance. The author Kierkegaard hides so to speak in the Governance and vice versa, whereupon any clarity in the text is disturbed (cf. Fraser, 2020, p. 166).

In a written text, something metamorphical and self-creative can occur which is then transformed into a kind of co-author or educator to the original author. We then have at least two 'authors' whereby the original author is the creator of his or her work, while the 'co-author', or Governance, helps educate the author. This is supported by Kierkegaard himself when he points out that "[i]t is Governance that has brought me up" (Kierkegaard, 1998, p. 77). As well as writing, the author is also being written so to speak. As described in Chapter 3, it is a case of letting oneself be poetically composed rather than composing oneself poetically. Not only is the author the source of his or her own authorship, but the authorship is also the source of the author's self. The self's confidence and certainty are unsettled because we end up being governed, educated and taught by our own writings. Through this unsettlement and disturbance, Governance forces us to re-evaluate, or perhaps adjust or reject, our previous beliefs. 
Yet is the idea of Governance compatible with educational research, regarding both the outside-in and the inside-out perspective? To me, the answer is yes because the choices you make as a researcher govern the direction of the work and the research. This applies to choices made both before, during and after the research. Governance is thus present in the collection and processing of data, in interviews and conversations, in analyses and preparation of questionnaires, as well as in the written forms of expression. For example, it is often the case that the researchers control the conversation with those who are interviewed, and this control will have certain consequences for the analyses after the interview. For example, the researcher's normative position can shine through the analyses. This is how Governance is present in both the actual research work and the writing process, which often takes place in parallel.

Since the choices you make- for example, choices about theory and methodsteer the analyses in certain directions, can you as a researcher then steer Governance? Yes, to some extent. By thinking through the choices in advance, one can to some degree postulate the governing of the analysis. But having said that, Governance will in any case appear as something that is beyond the researcher's control and normative stance. A reason for that is that a kind of irony appears in the form of a contradiction between the researcher's controlled choices and governings, and uncontrolled governings that appear in the research processes and in the written materials. This kind of irony is not only unforeseen, but it can also govern, discipline and educate the researcher. Let me elaborate.

When it comes to writing, researchers can look back at what we have written using ironic indirection - so that our writing becomes so much more than a resultoriented script. Rather, that which we have produced in writing becomes a kind of Bildungsroman that the authors themselves can look back on through an ironic lens - which in turn can disturb and unsettle our previous beliefs. Irony may thus be an important part of the researcher's own education.

At the same time, an ironic distance is needed in the research process- for example, to the data material and to the research on and with the participants. Let me take an example from the qualitative study that I described in Chapter 2. In this study, we made use of video recordings and interviews of teachers. When it comes to a traditional interview, it is often the case that researchers prepare questions in advance, perhaps independently of their data material. This makes it easy to surrender to decisions that are one-sidedly normative. The research team in this study, on the other hand, tried to acknowledge the Governance working in the material, in this case, it was the video recording. This is how we could see that the questions for the interview were in the material itself. It is about being guided by the data material and letting the questions come to you as a researcher. This was also the reason why we started with video recordings before we conducted the interviews. Again, it is a case of letting oneself be poetically composed rather than composing oneself poetically. This also means that the researcher's empirical material can in itself guide theoretical choices, as well as analyses and assessments away from predetermined assumptions and towards other directions than what I as a researcher expected in advance. 
To further involve Governance in the research, it may be an idea to think untraditionally when it comes to those who are being interviewed. Traditionally, it is the researcher who governs and controls the research process (cf. Høyland, 2021). The researcher prepares questions for the interview, while those who are being interviewed are almost treated as objects, as they are merely to appear as suppliers of data material. In the research language, they are called either interview object or informant, which strongly indicates that they are treated as objects who are supposed to give the researcher something.

In our study presented in Chapter 2, we went beyond this tradition as we involved the teachers in the research process. The teachers appeared as interlocutors, and indirect intermediaries; that is, they appeared as co-researchers who were involved in preparing questions based on the video recordings. In this way, we provoked a form of irony similar to one of Kierkegaard's ironic writing styles in which he used different pseudonyms to bring forth a plurality of voices (Fraser, 2020 , p. 166). The research team created a space for several voices that initially prevented clarity in this part of the research process. This also made room for several perspectives and viewpoints, in which the research team received an inside view (from the teachers) with direct access to EP and an outside view (from ourselves as researchers) with indirect access to EP. We could thus combine proximity to EP with sufficient distance. Metaphorically, we wore bifocal glasses, with both near and distance vision (cf. Høyland, 2021, p. 26). As researchers, we could let ourselves and our beliefs be guided and sometimes disciplined and unsettled by the teachers and by ourselves. Thus, new questions could be generated during the interview, not least questions that we as researchers could not discover on our own.

\section{Conclusion: Unsettling the omniscience in education by way of irony}

In this chapter, we have seen that the outside-in and inside-out perspectives have a common interest in EP.The aim of both perspectives is to improve EP, and they seek to produce a concrete result, an outcome, and not least something useful-something that can be used constructively in an educational practice setting in one way or another (Biesta, 2007). The problem with both perspectives is the certain belief in reliable information, a kind of omniscience. The outside-in perspective makes this omniscience clear in the form of the concept of evidence. The concept implies a belief in the results so great that they can be said to constitute evidence and be entitled to dictate what happens in EP (Terhart, 2011, 2014; Wecker, Vogel, \& Hetmanek, 2017). In the inside-out perspective, the omniscience manifests itself in that the information derived from EP does not have to be verified by way of ETH.

Eventually, EP will suffer from this, as we have seen in this chapter. On the one hand, EP is controlled from the outside, based on data that is considered as evidence. Because the data are 'evident,' the researchers have full confidence in them. As for teachers and practitioners, they are supposed to use these evidence-based findings in their teaching, even though the findings are based on a research language that does not resonate with the language generally used in EP. On the other 
hand, EP shall be governed on the basis of reflection-based research which is believed to be reliable information, even if the information or theory is weak or lacks thorough scientific verification and substantiation.

On this background, I have argued for connecting irony and educational research but not for the sake to make research better or for the sake of making schools or EP better by way of research. It is also not about seeking understanding, as is the case in the hermeneutic tradition, and in which the researcher appears as an interpretive subject. That said, I have not argued that interpretation shall not be part of educational research. Research will always have phases and processes where interpretation plays an important part. In addition, educational research needs criticism, self-criticism, doubt, and more.

My point is rather that irony can come as an addition or a supplement to traditional research methods and perspectives. As I have argued, irony can unsettle the omniscience in education research, and it may be beneficial when it comes to educational research. When irony points outwards it can, inter alia, destroy evidence by means of itself, causing hyper-intensifying change that remains in constant tension and motion. As such, irony may resist the demand for evidence-based education research to culminate in certainty.

When irony points inwards, the researcher may be disciplined and brought into subjection in the sense of becoming subjugated to their own research, which can indirectly steer and educate the researcher in new directions. More precisely, irony can disturb and unsettle the researcher's confidence and self-satisfied certainty, which can preclude the desire for certitude and homogeneity.

A final point: By way of irony, the researcher can think 'aporetically' (cf.Vasiliou, 2002). Aporia means impasse or no-way and indicates that the researcher keeps problems open (ibid.). The ironist researcher does not take anything for granted and does not seek results, usefulness or understanding. Thus, new questions can be revealed, which should be subjected to further ironic scrutiny.

\section{References}

Achinstein, P. (2001). The book of evidence. Oxford: Oxford University Press. DOI: 10.1093/019543892.001.0001

Balzer, N., \& Bellmann, J. (2017). Die Erziehung der Theaterperspektive. Zur Kritik der Dichotomisierung von Pädagogik und Erziehungswissenschaft. [The education of the theater perspective. A critique of the dichotomy of pedagogy and educational science]. Paper presented at Deutsche Gesellschaft für Erziehungswissenschaft, 8-10 March 2017, Phillips-Universität Marburg.

Bellmann, J., \& Müller, T. (Eds.) (2011). Wissen, was wirkt. Kritik evidenzbasierter Pädagogik [Know what works. A critique of evidence-based education]. Wiesbaden: VS Verlag für Sozialwissenschaften.

Bellmann, J. (2017). Forwards to the learning sciences or back to pedagogy? In H. Saeverot, \& T. Werler (Eds.), Pedagogikkens spräk [The language of education] (pp. 104-117) Oslo: Gyldendal.

Biesta, G. (2007). Why 'what works' won't work: Evidence-based practice and the democratic deficit in educational research. Educational Theory, 57(1), 1-22. 
Biesta, G. (2008). Bridging the gap between educational research and educational practice: The need for critical distance. Educational Research and Evaluation. An International Journal on Theory and Practice, 13(3), 295-301.

Biesta, G. (2010). Why 'what works' still won't work: From evidence-based education to value-based education. Studies in Philosophy and Education, 29(5), 491-503.

Borko, H., Liston, D., \& Whitcomb, J. A. (2007). Genres of empirical research in teacher education. Journal of Teacher Education, 58(1), 3-11.

Brezinka, W. (2015). Die 'Verwissenschaftlichung' der Pädagogik und ihre Folgen [The 'scientification' of pedagogy and its consequences]. Zeitschrift für Pädagogik, 61(2), 282-294.

Carr, W., \& Kemmis, S. (1986). Becoming critical: Education, knowledge and action research. London: Falmer.

Cochran-Smith, M., \& Donnell, K. (2006). Practitioner inquiry: Blurring the boundaries of research and practice. In J. L. Green, G. Camilli, \& P. B. Elmore (Eds.), Handbook of complementary methods in education research (pp. 503-518). Mahwah, N.J.: Lawrence Erlbaum Associates.

Cochran-Smith, M., \& Lytle, S. L. (1993). Inside/Outside:Teacher research and knowledge. New York: Teachers College Press.

Davis, J., Courtney, C., \& Broome, J. (2018). Thinking like researchers: action research and its impact on novice teachers' thinking. Educational Action Research, 26(1), 59-74 doi:10.1 080/09650792.2017.1284012

Elliott, J. (2004). Making evidence-based practice practical. In G. Thomas, \& R. Pring (Eds.), Evidence-based practice in education (pp. 164-186). Maidenhead: Open University Press.

Eraut, M. (2004). Practice-based evidence. In G. Thomas, \& R. Pring (Eds.), Evidence-based practice in education (pp. 91-101). Maidenhead: Open University Press.

Fraser, B. P. (2020). Hide and seek. The sacred art of indirect communication. Eugene, Oregon: Cascade Books.

Gadamer, H. G. (1965). Wahrheit und Methode [Truth and method]. Tübingen: J. C. B. Mohr.

Hattie, J. (2009). Visible learning: A synthesis of over 800 meta-analyses relating to achievement. New York \& London: Routledge.

Høyland, B. (2021). «Er jeg kritisk nok?» Refleksivitet i didaktisk forskning [«Am I critical enough?» Reflexivity in didactic research]. In H. Berdinesen (Ed.), Ny pedagogisk praksis [New pedagogical practice]. Oslo: Dreyers forlag.

Kelly,T. (2008). Evidence: Fundamental concepts and the phenomenal conception. Philosophy Compass, 3(5), 933-955.

Kemmis, S. (1988). Action research. In J. P. Keeves (Ed.), Educational research, methodology, and measurement: An international handbook (pp. 42-49). Oxford: Pergamon.

Kemmis, S. (2009). Action research as a practice-based practice. Educational Action Research. 17(3), 463-474.

Kemmis, S. (2012). Researching educational praxis: spectator and participant perspectives. British Educational Research Journal, 38(6), 885-905.

Kierkegaard, S. (1992a). The concept of irony. With continual reference to Socrates (H.V. Hong, \& E. H. Hong, Trans.). Princeton, NJ: Princeton University Press.

Kierkegaard, S. (1992b). Concluding unscientific postscript to philosophical fragments (H.V. Hong, \& E. H. Hong, Trans.). Princeton, NJ: Princeton University Press.

Kierkegaard, S. (1998). The point of view for my work as an author (H.V. Hong, \& E. H. Hong, Trans.). Princeton, NJ: Princeton University Press.

Kvernbekk, T. (2001). Teorityper og bruk av teori [Types of theories and use of theory]. In F.V. Nielsen, \& H. Jørgensen (Eds.), Nordisk musikkpedagogisk forskning (pp. 24-42). Oslo: NHMs skriftserie. 
Kvernbekk, T. (2005). Pedagogisk teoridannelse [Construction of pedagogical theory]. Bergen: Fagbokforlaget.

Kvernbekk, T. (2016). Evidence-based practice in education. Functions of evidence and causal presuppositions. New York \& London: Routledge.

Lear, J. (2011). A case for irony. Harvard: Harvard University.

Levinas, E. (2000). God, death, and time (B. Bergo, Trans.). Stanford, California: Stanford University Press.

Ljungdalh, A. K., Lysgaard, J. A., \& Tafdrup, O. A. (Eds.) (2017). Uddannelsesvidenskab: en kritisk introduktion [Educational sciences: A critical introduction]. Frederiksberg: Samfundslitteratur.

Malone, A., \& Hogan, P. (2020). Evidence and its consequences in educational research. British Educational Research Journal, 46(2), 265-280. https://doi.org/10.1002/berj.3580

McCardle, P., \& Miller, B. (2009). Why we need evidence-based practice in reading and where to find that evidence. In S. Rosenfield, \& V. Berninger (Eds.), Implementing evidencebased academic interventions in school settings (pp. 19-48). Oxford: Oxford University Press.

Michelfelder, D. P., \& Palmer, R. E. (Eds.) (1989). Dialogue and deconstruction: The GadamerDerrida debate. Albany, NY: SUNY Press.

Nehemas, A. (1998). The art of living: Socratic reflections from Plato to Foucault. Berkeley: University of California.

Nordahl,T. (2013). Gjør læring synlig. Forord til den norske utgaven [Make learning visible. Preface to the Norwegian version]. In J. Hattie (Ed.), Synlig laring [Visible learning] (pp. 17-22). Oslo: Cappelen Damm Akademisk.

Pirrie, A. (2001). Evidence-based Practice in Education:The Best Medicine? British Journal of Educational Research 49(2), 124-136. https://doi.org/10.1111/1467-8527.t01-1-00167

Reason, P., \& Bradbury, H. (2008). Introduction. In P. Reason, \& H. Bradbury (Eds.), The $S A G E$ handbook of action research: Participative inquiry and practice (pp. 1-10). London: Sage.

Ricoeur, P. (2016). Hermeneutics and the human sciences: Essays on language, action and interpretation. Cambridge: Cambridge Philosophy Classics.

Roberts, P., \& Saeverot, H. (2018). Education and the limits of reason: Reading Dostoevsky, Tolstoy, and Nabokov. New York \& London: Routledge.

Rorty, R. (1989). Contingency, irony, and solidarity. Cambridge: Cambridge University Press.

Saeverot, H., \& Kvam, V. (2019). An alternative model of researching educational practice: A pedagogic-stereoscopic point of view. British Journal of Educational Research, 45(1), 201-218.

Simons, H. (2003). Evidence-based practice: Panacea or over promise? Research Papers in Education. 18(4), 303-311.

Smeyers, P. (2005). Idle research, futile theory, and the risk for education: Reminders of irony and commitment. Educational Theory, 55(2), 165-183.

Smeyers, P. (2006). The relevance of irrelevant research; the irrelevance of relevant research. In P. Smeyers, \& M. Depaepe (Eds.), Educational research:Why "What Works" doesn't work (pp. 95-108). Dordrecht: Springer.

Smeyers, P., \& Depaepe, M. (Eds.) (2006). Educational research:Why “What Works” doesn't work. Dordrecht: Springer.

Smith, R. (2020). Unsettling knowledge. Irony and education. Journal of Philosophy of Education, 53(3), 757-771. https://doi.org/10.1111/1467-9752.12444

Stenhouse, L. (1975). An introduction to curriculum research and development. London: Heinemann.

Tenorth,H.-E. (1994). Profession und Disziplin. Zur Formierung der Erziehungswissenschaft. [Profession and discipline. On the formation of educational science]. In H.-H. Krüger, \& T. Rauschenbach (Eds.), Erziehungswissenschaft. Die Disziplin am Beginn einer neuen Epoche [Educational science. The discipline at the beginning of a new era] (pp. 17-28). Weinheim: Juventa-Verlag. 
Terhart, E. (2011). Has John Hattie really found the holy grail of research on teaching? An extended review of visible learning. Journal of Curriculum Studies, 43(3), 425-438.

Terhart, E. (Ed.) (2014). [Discussion of the Hattie study: Making problems visible]. Seelze: Kallmeyer, Klett.

Thomas, G., \& Pring, R. (Eds.) (2004). Evidence-based practice in education. Maidenhead: Open University Press.

Tiller, T., \& Brekke, M. (2017). Læreren som forsker og den nye utdanningsveien [The teacher as researcher and the new way of education]. In M. Brekke, \& T. Tiller (Eds.), Lareren som forsker [The teacher as researcher] (pp. 277-284). Oslo: Universitetsforlaget.

Ulvik, M. (2017). Aksjonsforskning - en oversikt [Action research - an overview]. In M. Ulvik, H. Riese, \& D. Roness (Eds.), A forske på egen praksis [To research on one's own practice] (pp. 17-35). Bergen: Fagbokforlaget.

Ulvik, M., \& Riese, H. (2016). Action research in pre-service teacher education - a neverending story promoting professional development. Professional Development in Education, 42(3), 441-457. doi:10.1080/19415257.2014.1003089

Ulvik, M., Riese, H., \& Roness, D. (2017). Action research - connecting practice and theory. Educational Action Research, 26(2), 273-287. doi:10.1080/09650792.2017.1323657

Goor, R. van, \& Heyting, F. (2006). The fruits of irony: Gaining insight into how we make meaning of the world. Studies in Philosophy and Education, 25(6), 479-496.

Vasiliou, L. (2002). Socrates' reverse irony. The Classical Quarterly, 52(1), 220-230. Doi:10.1093/cq/52.1.220

Vlastos, G. (1991). Socrates, ironist and moral philosopher. Cambridge: Cambridge University Press.

Wecker, C., Vogel, F., \& Hetmanek (2017).Visionär und imposant - aber auch belastbar? [Visionary and impressive - but also reliable?]. Zeitschrift für Erziehungswissenschaft, 20(1), 21-40. https://doi.org/10.1007/s11618-016-0696-0 


\section{Afterword}

\section{The wisdom of teachers. A conversation with three teachers}

In the previous pages, I have argued that both educational research and teaching should go the belief in useful and reliable knowledge, as well as explicit and direct forms of teaching. In both educational research and teaching, one should know when it is most appropriate to be direct and indirect in an educational and ethical perspective, and not least when the two forms should be combined. In this afterword, I wish to know what teachers have to say about this. In the following conversation, we meet "Robert" and "Eve" who teach in ninth grade and "Peter" who teaches in sixth grade. The conversation does not have a monocular or single point of view where the four of us agree on everything. Rather, our viewpoints meet, but they do not necessarily confirm each other.

HERNER: In the visible learning paradigm, it is the teacher who shows and instructs the students what to do and how to do it. While the teacher points out the directions for the students, the students must trust the teacher's directives and instructions. This not only creates a strongly teacher-driven teaching, but it also generates a narrow view of knowledge and of education itself. As for the students, they have to put their trust in others than themselves. Therefore I have argued that education should open up to other forms of teaching than just the direct form. There should be a time to be direct and a time to be indirect. Besides, it is often the case that direct and indirect teaching occur in interaction, that is, directness and indirectness intertwine, without being divided.Teachers, so I have argued, must assess which form or forms, either DI, ISS or ISU/DIT, is or are most appropriate based on the purpose of the particular situation. Now, you stand in the classroom every single day, and I wonder, what do you think about these arguments?

ROBERT: I think that in some areas, in particular areas on how to behave towards classmates and others-for example, related to social media and bullying- the teacher should make use of both direct and indirect approaches. Through indirect approaches, the students are given space to reflect independently on questions about attitudes and behaviour. However, teachers should also show some guidance and stand forth as good role models. What attitudes one should have towards other people, and how we behave in the best possible way in a community, thus require both directness and indirectness.

DOI: $10.4324 / 9781003193463-9$ 
HERNER: But is it not a risk that teachers control what kind of attitudes the students should have, how they should think and act, and, as a result, fail to educate self-thinking individuals? Not long ago I observed this myself. I was present in a physical education lesson in primary school. The students, aged seven or eight, were playing football when suddenly the ball landed at the feet of one of the boys. The teacher stood on the sidelines and pointed and shouted what the boy should do with the ball. The boy looked at the teacher as he tried to run with the ball in the direction that was pointed out but stumbled in his own legs and fell. It is easy to fall when one has to lean on others as if they were a crutch.

ROBERT: Yes, that is something to watch out for. Last year, when I was teaching about the US election campaign, I had to make sure that I did not influence the students to choose sides. If teachers are not aware of this, they can easily influence the students' opinions. This should be avoided. When I was a student, I had a teacher who was Christian, and even though I never thought it was his intention to influence our opinions, his Christian values shone through the teaching. That was probably not his intention, but it happened anyway. So I think it's very important to be aware of how much influence you actually have as a teacher. It is important to let students to think independently, reflect, argue and talk about different phenomena, without direct, or even indirect, influences from us teachers.

PETER: I think that indirect approaches in teaching create more opportunities for wonder and curiosity in the classroom. It allows students to have a more open dialogue between themselves. However, a prerequisite for this is that the students are engaged in the same subject and topic.

HERNER: Let me challenge you by asking, Is not indirectness in education too hazardous? Should not indirectness in teaching be avoided? In the previous pages, I pointed out that the Nazis brainwashed their people through indirect communication because they wanted to achieve an advantage (Chapter 3), while teacher Bjørndal had good intentions, but failed ethically because he was simply not aware of the negative and damaging effects of his indirect strategy (Chapter 4).

EVE: Yes, you can manipulate, and you can oppress your students through the language. So, teachers must really be aware of this.

HERNER: You touch upon an important issue, that teachers and others must be aware of whenever they choose to communicate indirectly. For example, one can be indirect and at the same time moralise. One can even, as you say, be oppressive through indirect speech. Imagine that a group of people come together. $\mathrm{X}$ has been annoyed that $\mathrm{Y}$ is constantly travelling by plane. $\mathrm{X}$ explains to the group about how bad it is for the environment to travel by plane. Instead of saying this directly to Y, X approaches the whole group. X thus acts indirectly. $Y$ is treated as an object, and certainly not as a subject, who is indirectly suppressed and moralised by X. The point is that one can be indirect even though one's message is crystal clear. This is a form of pedagogical moralisation. However, this is only one side of the Janus face. Indirect 
communication has, as I have repeatedly argued, a Janus face. These forms of communication do not just have a negative side which is destructive to the recipients. They also have a positive side, as they can be fruitful in educational situations. In sum, this form of communication can be both destructive and educative for the recipient. Take irony for example. Many associate irony with expressing the opposite of what one means. The problem with this form of irony is that it confronts the recipient with an interpretive task where the answer is either correct or incorrect. It's easy to misunderstand.

ROBERT: Some may recall an incident that happened in 2001. Many students in upper secondary school failed the exam because they had misunderstood the irony of a Norwegian author. If I remember correctly, there were over 2,000 students who failed the exam because they did not understand the irony.

HERNER: Yes, it's incredible, and such things happen because irony is defined as meaning the opposite of what you say. It is an understanding of irony that lingers and it seems difficult to get rid of. In Kierkegaardian irony, on the other hand, it is not a matter of having a correct understanding of irony. Rather, the point is to upbuild and educate the recipient on an existential level. Due to the negative and positive side of irony, and indirect communication in general, I believe teachers should be very well trained, while being aware and sensitive, to use such forms of communication.

EVE: I totally agree. Ideally, training in indirect communication should be implemented in teacher education. Teacher students should also be trained to adapt the indirect communication to different ages because I would think that this is a bit age-specific. I would think that eighth to tenth graders are more receptive to indirect teaching methods. My experience is that one can be quite indirect and open, as well as asking critical and ethical questions, to the students at this age level.

PETER: My experience is that indirect approaches also work well for younger children. But I think that the students' prior knowledge must be in place for it to have any value. At the same time, students are very individual, some have a lot of prior knowledge of a topic while others have almost nothing. The students are unique individuals who are triggered by different approaches and tasks. Some are more philosophical who enjoy dwelling; they like to wonder about things.

ROBERT: The class, too, affects the teaching to a great extent. As a teacher, you quickly understand what works and what does not work, and what time of the day you can carry out different teaching-related assignments. There are also different teaching strategies and approaches that work in different classes; however, what works in one class may not work in another. Class size is also important. Generally, it is more difficult to be successful with certain strategies and approaches in a larger class. But of course, individual students may also influence the teaching as a whole. Last but not least, it is the resources that provide opportunities or obstacles with regard to teaching.

HERNER: There are several things to note in what you say. For one thing, indirectness is not about methods that have been developed in advance, after which the 
methods can be used in specific situations. It is rather a question of forms of communication and teaching-that is, forms that must be developed there and then, for each and every specific situation. This is of course very demanding, but this is the only way to adapt indirectness to situation and context, as well as classes, individual students and age levels. Another thing that comes to my mind is that the use of directness and indirectness is culturally dependent. Some cultures are more indirect in their communication than others, while other cultures communicate more directly. That said, cultures can change. For example, by using indirect forms of communication, be it irony, humour, wit, understatements and so on, early in child-rearing, both in kindergarten and primary school, children at a young age will become accustomed to these forms of communication. This in turn will make it easier for the children to deal with these forms of communication, which they will sooner or later encounter in different contexts. In addition, it will be easier for teachers to use indirect pedagogy in both kindergarten and school. Some may perhaps assert that such a change of culture is impossible to achieve. Maybe. In any case, it would be highly demanding, as one would be dependent on many factors. A great push towards this goal would be to include indirectness into both the curriculum and teacher education. Both teacher students and teachers should in my view practice all kinds of indirectness in relation to teaching so that they are prepared, being able to 'improvise' in any situations that might occur in educational practice. Thus the paradox arises, as one must be very well prepared to be able to improvise.

PETER: The school is unfortunately overrepresented by direct teaching, but I think that very many teachers wish that this type of teaching should be reduced. However, in a hectic everyday life, it is probably easier to organise direct forms of teaching. Teachers can also easily report that the students did something, you simply get something on paper. On the other hand, I do believe that the advantage, or the reward if you like, is greater in the long run by prioritising indirect teaching, although there is a risk that this approach does not benefit all the students. The most important thing is probably to vary the teaching between direct and indirect approaches as best you can.

HERNER: You touch upon the time aspect here, and one may in a challenging way ask: Is there time for indirectness in education? I ask because we live in a time of urgency. Directness, with its impatience, is very well compatible with our time. For example, in the visible learning paradigm, everything that is invisible, indirect and relatively time-consuming must be weeded out. One sees only the value in usefulness and effective learning outcomes. The danger of such an ideology is that students are taught to look at the world in a linear way and to interpret things too literally. When students then face indirectness, they may be completely helpless, like an illiterate. As long as the world is full of indirectness, it should in my view also be implemented in teaching contexts. Indirectness, with its patience, on the other hand, is not very compatible with our time. Let me, therefore, cite some relatively startling words from Jean-Jacques Rousseau's (1712-1778) novel Emile, or On Education (1762): “May I venture at this point 
to state the greatest, the most important, the most useful rule of education? It is: Do not save time, but lose it" (Rousseau, 2003, p. 67). This idea does not fit well with the visible learning paradigm, which is concerned with efficiency. In the visible learning paradigm, efficiency means gaining time and to accomplish that, explicitness and directness are used in the teaching. This constant urge to gain time creates a blindness towards indirectness, which implies that an education that takes time can actually gain time. Time is here thought of as quality, as opposed to time as calculation, where education is likely to be nullified due to its connection to a time frame which is determined in advance.

ROBERT: I agree that the school is becoming more and more concerned with gaining time. This is shown, among other things, by the fact that the school has been strongly goal-oriented, where direct forms of teaching are becoming more and more dominant. One reason for this is that teachers must stick to the syllabus, and the teaching is measured through exams and national tests. But as they say, haste makes waste.

EVE: We must dare to break with this time pressure in school. For my part, I strive to indirectly encourage the students to reflect on difficult issues and discuss ethical dilemmas among themselves. Yes, perhaps even grotesque dilemmas such as issues related to war and human rights violations. It is not about making the students think that something is wrong, or that something is right. I want them to be able to see the whole picture of things, including causes and consequences. The students should reflect and argue for their views, aiming to reach good reasons for their opinions. Ultimately, I strive to teach in such a manner, I guess through indirectness, that everything leads back to the individual student's self-reflection and self-insight.

PETER: I also think that with indirect teaching approaches-both specified and unspecified-you have to dare to stay in there. One must dare to trust the process. As a teacher, you must dare to go outside your own comfort zone, provide more freedom to the students and then dare to stand in the chaos that may arise. It's exciting to see where this leads us because sometimes it leads us to surprising and interesting places.

HERNER: Thanks very much for sharing your wisdom. Let's hope that your ideas, as well as the many claims, hypotheses and questions in this book, inspire further research on indirectness in education.

\section{Reference}

Rousseau, J.-J. (2003). Émile (B. Foxley, Trans.). London: Everyman. 


\section{Index}

Note: Page numbers in Italics refer to figures; bold refer to tables and boxes and page numbers followed by ' $n$ ' refer to notes numbers.

Achinstein, P. 106

action learning 111

action research 98, 108, 110, 111

Anglo-American tradition of education 90 anti-bullying programmes 65

Anti-Climacus' thought experiment 49-51, 56-57

art of teaching 81

autonomy 92

Bellman, J. 110

Bergens Tidende newspaper 62

Biesta, G. 106, 108

Bildung process 47

Bjorndal's method 62-65; direct communicative form 66-68; ethically legitimised 73-74; hypothetical alternative to $74-76$; preventing responsibility, for bullying 68-70; repercussions of 70-73; unorthodox and indirect method 65-66

Bollnow, O. F. 50, 67; educational theory 68 Brezinka, W. 109

bullying at lower-secondary school 61-63; Bjorndal's method see Bjorndal's Method; exemplary method 64 ; indirect method 65-66; preventing responsibility for 68-70

Caesar, Julius 79

case study: Elisabeth 39-40; foreign boys 37-39; of 'John 81-85

clock time 79, 85

communication: Bjorndal's form of 66-68; deceit form of 41-45; definition of 35; irony form of 36-40, 51-54; visual 45-51 communication theory: increased awareness of indirectness through 8-9; intermediaries see intermediaries awareness, in teaching continental Pädagogik tradition 90-91, 103n1, 109

conventional theory 114

COVID-19 pandemic 55

creative and cunning method 73

criticism 11, 53

cyberbullying 61

deceit form, of communication 41; educated/deceived by $54-56$; educated directly by 44,44 ; educated indirectly by $44-45,45$; grooming 43 ; seduction 41-43

deception 41,43

Democracy and Education (Dewey) 81

destruction process 47

Dewey, John 92; genuine time 85-88; theoretised thoughts about time 81-85; time and interaction 80-81

DI see direct instruction

digitalised society 41

direct communicative form 66-68

direct-indirect teaching (DIT) 27, 27-29, 30,32

direct instruction (DI) 1, 21, 21-22, 24-25, $28,29,30,32$

discontinuous education 67-68

Disruption-effect (D-effect) 47-49

DIT see direct-indirect teaching double purpose, of education 1, 18-20, 22, 29,31 
education, directness and indirectness $1-5,3$

Education Act 69

educational practice (EP) 23, 90, 91, 92, 93, 106-107; direct access to 98, 99; disciplines examining 95; educational research in 110-111; inside-out perspective and problems 109-110; knowledge and theory for 100; outside-in perspective and problems 108-109; research process 102; understandings of 101 ; in visible learning paradigm 97

educational/education research: direct and indirect paths 90, 93; educational practice 106-107, 110-111; irony $107-$ 108, 111-117; omniscience in 108-111 educational sciences (ESS) 90, 91, 94; indirect source of knowledge, for ETN 95-96; inter-disciplinary structure of 95; vs. education as task 98

educational theory 93, 97, 98, 100, 102, 103

education as task (ETK) 91, 93, 94, 101, 102; directness through 97-100

education as translation (ETN) 91, 93, 100; educational knowledge 102; indirectness through 94-96, 98-100

education as truth (ETH) 91, 93, 94; indirectness through 100-102; irony to 112

educative deceit 41

Edwards-Groves, C. 97

Eilertsen, Trine 62, 64, 67-68, 70-74

Eisner, Elliot 50

Elisabeth case study 39-40

Emile, or On Education (Rousseau) 69, 125-126

EP see educational practice

epistemology 32

ESS see educational sciences

ETH see education as truth

ethical and unethical actions see bullying at lower-secondary school

ETK see education as task

ETN see education as translation

evidence-based practice 106

exemplary method 64

existence, visual communication 45-46

Existentialism and Education (Bollnow) 67

Fichte, Johann Gottlieb 19

foreign boys case study 37-39

The Fortune Teller (Caravaggio) 42 fourth model of teaching 27, 27-29

Francke, August Hermann 46

genuine time 80-81, 85-88

Goebbels, Joseph 42, 43

good communication 35,55

Governance 115-117

Gregorian calendar 79

Hattie, John 1, 21, 108, 111

Hegel, Georg Wilhelm Friedrich 113

Heimskringla (Sturluson) 15

Hitler's Generals (Knopp) 42

hyper-dialectical forces, of deceit 44

indirect coercion and responsibility $72-73$

indirect manoeuvre 30

Indirect Pedagogy. Some Lessons in Existential Education (Saeverot) 1

indirect summoning which is specified (ISS) 22, 22-23, 25-26, 29-31, 30, 32

indirect summoning which is unspecified

(ISU) 23-24, 24, 26-28, 30, 31

indirect 'test' 31

informant 117

initiating phase, of education 10

inter-disciplinary approach 91, 93

intermediaries awareness, in teaching 4,73 ; achieving justice 14-15; arouse reflection 13-14; being polite and humble

15; bold actions and permissiveness

11-12; controlling 10-11; multiple exits

15-16; protecting oneself 14 ; reducing tensions 13

interview object 117

irony, education research 107-108, 111-

112; combined with humour 51-54;

concept of 36-37; Elisabeth case study

39-40; foreign boys case study 37-39;

pointing inward 115-117; pointing

outward 112-115

ISS see indirect summoning which is specified

ISU see indirect summoning which is unspecified

Janus-faced forms, of communication 36 Julian calendar 79

justification $7-8$

Kelly, T. 106

Kemmis, S. 97, 109

Kierkegaard, S. 37, 41, 45-47, 53-54, 58n3, 107, 111-115, 117 
Kierkegaardian repetition, of AntiClimacus' thought experiment 49-51

Knopp, Guido 42

knowledge of Christianity, religion, philosophies of life and ethics (KRLE) $20,25,26,29,30,31$

Kvernbekk, T. 106, 109

Levinas, E. 64, 65, 71

McMurray, F. 103

"mediocre method of didacticizing," 53-54

National Socialism 42

National Socialist Party 43

neoliberal education 79-80

non-educational knowledge 99

non-verbal communication 9

Norwegian secondary school 20

Olweus, D. 61

omniscience, in education research 108-111

philosophical principles 92

poor communication 35

power 25-28; as indirect educational means $71-72$

practice-based knowledge 93

Practice in Christianity (Kierkegaard) 47

practice-oriented research 111

practitioner research 110

praise intermediary 11

Prange, Klaus 90

primitiveness 47

quantitative and qualitative research 110

reality, of crises 55

repetition effect 50

research-based theories 109

research literature 110

Rorty, R. 103

Rossiter, A. 74

Rousseau, J.-J. 69, 125-126

The SAGE Handbook of Action Research:

Participative Inquiry and Practice 110

school bullying 61

science of education (SE) 91, 92, 94;

directness through ETK 97-98;

indirectness through ETN 94-96; strong

and autonomous discipline, emerge

as 102-103; structure of 94; theory's

function 100
SE see science of education

seduction 41-43, 57n1

self-activity 19

self-criticism 101

social science teachers $26-27,30$

sociology, of education 92

The Sources of a Science of Education (Dewey) 92

Spener, Philipp Jacob 46

state-controlled education 86

Stoltenberg, Jens 64

straightforward approach 2

strong theory 100

students' existence 2

students' responsibility, to prevent bullying 68-69

Sturluson, Snorri 15

summoning intermediary 11

TA see teacher's assistant

Teacher Bjorndal's Method see Bjorndal's

Method

teacher research 110

teacher's assistant (TA) 83-85

teachers conversation 122-126

teacher's 'weak' approach 75-76

teaching, direct and indirect approaches

in: analysis 20; direct-indirect teaching

27, 27-29, 30; direct instruction 21,

21-22, 24-25, 29, 30; double purpose,

of education 18-20,29; indirect

summoning which is specified 22 ,

22-23, 25-26, 29-30, 30; indirect

summoning which is unspecified 23-24,

24, 26-27, 30, 31; undemocratic attitudes

18; unforeseeable situations $33 \mathrm{n} 1$

time 79; genuine 80-81, 85-88;

observation object and school

situation 81-85

Time and Individuality (Dewey) 80

transfer problem 95-96

undemocratic attitudes 18-20, 32

unlearning process 47

'the victim', of bullying 70-71

Visible Learning (Hattie) 1, 21, 108, 111

visible learning paradigm 1, 21, 97

visual communication: Anti-Climacus' thought experiment 49-51, 56-57; being and letting oneself 46-47; Disruptioneffect 47-49; existence 45-46

Wannsee Conference in Berlin 13 